\title{
USO DO BIOFILME PERIFÍTICO EM TESTES ECOTOXICOLÓGICOS: UMA ABORDAGEM ECOLÓGICA DA CONTAMINAÇÃO EM RESERVATÓRIOS
}

Use of Periphytic biofilm in ecotoxicological tests: An ecological approach on reservoir contamination

Mariana Lopes de Sousa

São Paulo

2019 
Universidade de São Paulo

Instituto de Biociências - Departamento de Ecologia

Mariana Lopes de Sousa

USO DO BIOFILME PERIFÍTICO EM TESTES

ECOTOXICOLÓGICOS: UMA ABORDAGEM ECOLÓGICA DA

CONTAMINAÇÃO EM RESERVATÓRIOS

Use of Periphytic biofilm in ecotoxicological tests: An ecological approach on reservoir contamination

Tese apresentada ao Instituto de Biociências da Universidade de São Paulo para obtenção do título de Doutor em Ciências, na área de Ecologia.

Orientador: Prof. Dr. Marcelo Luiz Martins Pompêo

Co-Orientadora: Prof. Dra. Fanly Fungyi Chow Ho

São Paulo

2019 
Ficha catalográfica elaborada pelo Serviço de Biblioteca do Instituto de Biociências da USP, com os dados fornecidos pelo autor no formulário:

http://www.ib.usp.br/biblioteca/ficha-catalografica/ficha.php

Sousa, Mariana Lopes de

USO DO BIOETLME PERIEITICO EM TESTES ECOTOXICOLOGICOS: UMA ABORDAGEM ECOLOGICA DA CONTAMINAÇAO EM RESERVATORIOS

/ Mariana Lopes de Sousa; orientador Marcelo Luiz

Martins Pompêo. -- Sảo Paulo, 2019.

$146 £$.

Tese (Doutorado) - Instituto de Biociências da Universidade de Säo Paulo, Departamento de Ecologia.

1. Ecotoxicologia. 2. Limnologia. 3. Perifiton. 4. Microalgas. 5. Ecologia Aquatica. I. Pompêo, Marcelo Luiz Martins, orient. II. Titulo.

Bibliotecária responsável pela estrutura da catalogaçăo da publicaçăo: Elisabete da Cruz Neves - CRB - 8/6228 


\section{Folha de Avaliação}

SOUSA, Mariana Lopes. Uso do biofilme perifítico em testes ecotoxicológicos: uma abordagem ecológica da contaminação em reservatórios. 2019. 146 f. Tese (Doutorado em Ecologia) - Instituto de Biociências, Universidade de São Paulo, São Paulo, 2019.

Aprovado em:

Banca Examinadora:

Prof. Dr.

Instituição:

Julgamento:

Prof. Dr.

Instituição:

Julgamento:

Prof. Dr.

Instituição:

Julgamento 


\section{Dedicatória}

Dedico esse trabalho aos meus pais Jesus e Rosa, e ao meu padrinho José Luiz, pelo incentivo à minha formação acadêmica desde o princípio. Ao meu marido Rodrigo pelo apoio desde a graduação, mesmo à distância. E á minha avó Carmela, que já não está mais aqui. 


\section{Epígrafe}

"Mas há muitas coisas que não se aprendem só pensando, é preciso vivêlas."

Michael Ende - A história sem fim

“Ter consciência da ignorância é o início da sabedoria. Mas quando você começar a aprender, não precisará esquecer todas as coisas que pensa conhecer."

Marion Zimmer Bradley - As Brumas de Avalon: A Senhora da Magia 


\section{Agradecimentos}

Ao meu orientador, Prof. Dr. Marcelo Luiz Martins Pompêo, pela disposição em me aceitar desde o ínicio e pela confiança no meu trabalho e apoio durante esses quatro anos.

Á minha co-orientadora, $\operatorname{Prof}^{\mathrm{a}} \operatorname{Dr}^{\mathrm{a}}$ Fanly Fungyi Chow Ho, essencial para a realização das análises de potencial fotossintético, além da disposição em revisar e colaborar com a produção dos manuscritos.

Á Prof $^{a} \operatorname{Dr}^{\mathrm{a}}$ Déborah Yara Alves Cursino dos Santos, pela colaboração e disponibilidade em realizar as análises de cafeína, bem como à equipe do Laboratório de Fitoquímica.

Aos membros do comitê de acompanhamento: Prof Dr. Julio López-Doval e Prof ${ }^{a}$ Dr. Ana Lúcia Brandimarte, pelo direcionamento durante esse período.

Ao Prof. Dr. Sérgio Tadeu Meirelles, pelas informações e ajuda na etapa de delineamento experimental.

Á Prof ${ }^{\mathrm{a}}$ Dr $^{\mathrm{a}}$ Viviane Moschini-Carlos, pelas informações e treinamento na etapa de identificação taxonômica.

Ao técnico Maurício Perine, pela ajuda com as análises de nitrogênio Kjeldahl.

Á Prof ${ }^{a}$ Dr $^{a}$ Sheila Cardoso de Melo, pelas análises de bioacumulação de metais, e suporte durante toda essa etapa.

Ao Phillipe Riskalla Leal, por ceder material e dados para a etapa de testes com sedimentos.

Á Vera Lucia Lúcia Barboza Lima, pela paciência e disposição em ajudar nas minhas inúmeras dúvidas.

Aos membros do Laboratório de Limnologia pela companhia e respeito durante esse período.

Á minha família, meus pais Jesus e Rosa e meu marido Rodrigo, por entenderem minhas escolhas. 


\section{Resumo Geral}

\section{SOUSA, Mariana Lopes. Uso do biofilme perifítico em testes ecotoxicológicos: uma}

abordagem ecológica da contaminação em reservatórios. 2019. 146 f. Tese (Doutorado em Ecologia) - Instituto de Biociências, Universidade de São Paulo, São Paulo, 2019.

O perifíton é uma comunidade complexa e de grande importância para os ecossistemas aquáticos. Seu papel de produtor primário, aliado a sua capacidade de reter nutrientes ou contaminantes presentes na coluna d'água o torna um bioindicador de potencial único para estudos ambientais. Especialmente no caso de reservatórios urbanos, que possuem múltiplas fontes de contaminação, compreender como essas substâncias afetam a biota e a qualidade da água é essencial. Por isso, é relevante o desenvolvimento de testes ecotoxicológicos utilizando a comunidade perifítica. Neste trabalho foi desenvolvida uma metodologia para cultivo do perifíton em laboratório, através de tanques de cultivo, visando seu uso em testes ecotoxicológicos para o monitoramento de ambientes aquáticos. $\mathrm{O}$ biofilme cultivado também foi testado com diferentes contaminantes encontrados em reservatórios: metais $(\mathrm{Cu}$ principalmente) e cafeína, buscando identificar os impactos desses contaminantes tanto nessa comunidade como em seus consumidores. Foi observado que o método proposto foi capaz de criar um biofilme perifítico funcional, com todos os principais grupos presentes na comunidade utilizada como inóculo e homogeneamente distribuída no substrato artificial utilizado. Entretanto foram observadas diferenças em relação ao inóculo, como menor diversidade e menor massa seca livre de cinzas, resultantes da adaptação da comunidade para o cultivo laboratorial. O preço final do sistema é competitivo com outras metodologias já utilizadas, com a vantagem de possuir fácil montagem e operação. Em relação às respostas da comunidade perifítica, foi observado que a presença de metais, em especial o cobre, resultou em impactos estruturais e fisiológicos na comunidade. Em geral a contaminação gerou alterações na produção de biomassa e menor ponto de saturação luminosa, um indicador do comportamento fotossintético. Além disso, foi possível constatar bioacumulação de diferentes metais ( $\mathrm{Cu}, \mathrm{Ni}$ e $\mathrm{Mn})$, bem como de cafeína, um composto orgânico. Ecologicamente, o grupo de algas mais afetado pelos contaminantes em geral foi o das Chlorophyceae, enquanto as cianobactérias apresentaram maior adaptação tanto às condições de cultivo quanto aos contaminantes utilizados. No caso da contaminação por cafeína em especial, as diatomáceas também se mostraram bem adaptadas. Nas maiores concentrações de contaminantes 
utilizadas, em geral, foi observado menor número de espécies descritoras e diversidade. Portanto, pode-se dizer que a metodologia de tanques desenvolvida e o teste toxicológico aplicado foram satisfatórios em trazer novos dados para a compreensão do funcionamento de ecossistemas aquáticos contaminados.

Palavras chave: Ecotoxicidade, Qualidade da água, Ecossistemas Aquáticos, Microalgas, Mesocosmos. 


\section{General Abstract}

\section{SOUSA, Mariana Lopes. Use of Periphytic biofilm in ecotoxicological tests: An ecological}

approach on reservoir contamination. 2019. 146 f. Tese (Doutorado em Ecologia) Instituto de Biociências, Universidade de São Paulo, São Paulo, 2019.

Periphyton is a complex and important piece of aquatic ecosystems. Due to its role as primary producer, and the capacity of assimilating both nutrients and contaminants from the water column, the biofilm constitutes an important bioindicator for environmental studies. Especially in urban reservoirs, impacted by multiple sources of contamination, the comprehension of how contaminants can affect the local biota and water quality is essential. That being said, the developing of ecotoxicological tests using periphyton is very useful. In the present work, a methodology for cultivation of periphytic biofilm in laboratory, using culture tanks was developed and discussed. The objective was the use in ecotoxicological tests for environmental monitoring, especially urban reservoirs. Cultivated and standardized biofilm was also tested through exposition using different contaminants: metals found in contaminated reservoirs ( $\mathrm{Cu}$ specially) and caffeine. It was expected to identify the impacts of these substances on the microalgae, and possible impacts in food chain. Results showed that the proposed methodology was enough to enable the growth of a functional periphyton, with all the main algal groups observed on the inoculum. The biofilm was also homogeneously distributed on the artificial substrate used. However, some differences were observed, such as lower diversity and lower ash free dry mass if compared to the original inoculum. This is can be considered an effect of periphyton adaptation to the controlled laboratory conditions. The final price of the system used is competitive if compared to other methodologies commonly used for periphyton cultive, with the advantage of being easily mounted and operated. When applied to ecotoxicological tests, the periphyton exposed to metals, specially $\mathrm{Cu}$, suffered ecological and physiological alterations. In general, contamination generated alterations in biomass production and shorter light saturation point, and indicator of photosynthetic behaviour. Besides that, it was possible to observe bioaccumulation of metals $(\mathrm{Cu}, \mathrm{Ni}$ and $\mathrm{Mn}$ ) and caffeine on the mucilage of periphyton. Ecologically, the most affect algal group in ecotoxicological tests was the green algae (Chlorophyceae), while cyanobacteria were better adapted to both laboratory conditions and contamination. In caffeine presence especially, diatoms were also resistant. In the highest concentrations of contaminants used (both metals 
or caffeine), it was observed a smaller number of descriptive species, and lower diversity. Nevertheless, it is possible to conclude that the methodology of culture tanks used was satisfactory in providing new data about the comprehension of the functioning of contaminated aquatic environments.

Keywords: Ecotoxicity, Water quality, Water ecosystems, Microalgae, Mesocosms. 


\section{Sumário}

INTRODUÇÃO GERAL ..................................................................................................15

Referências ..............................................................................................................20

Capítulo 1 - O PERIFÍTON E SEU PAPEL COMO PRESTADOR E INDICADOR DA QUALIDADE DE SERVIÇOS ECOSSISTÊMICOS ...........................................................23

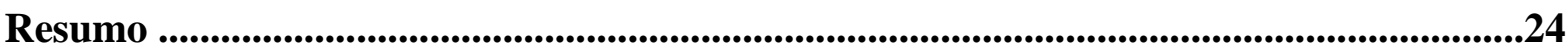

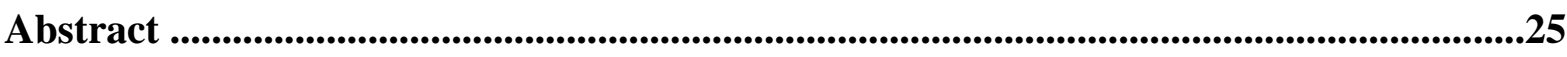

Introdução ...........................................................................................................................................26

Metodologia .....................................................................................................................2

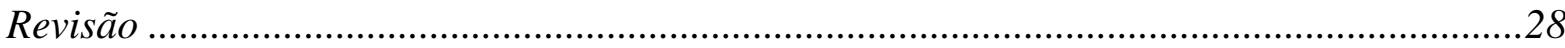

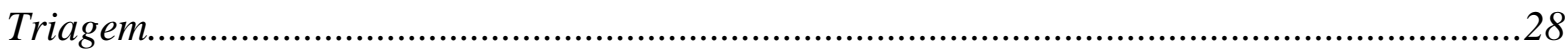

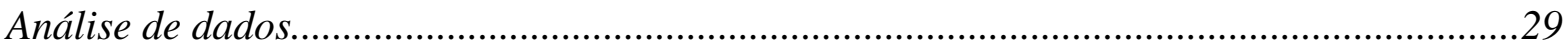

Resultados e Discussão ......................................................................................................................29

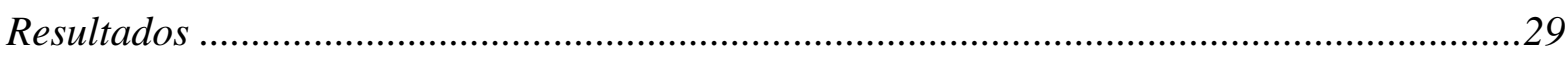

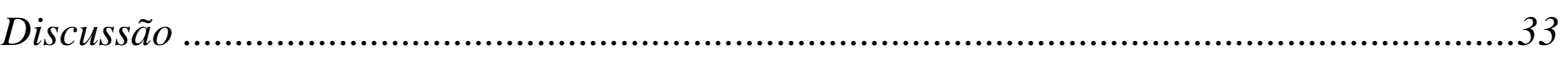

Natureza dos dados e distribuição espacial dos estudos .............................................33

Relação entre uso e ocupação do solo x abordagem e importância do perifíton .......34

Influência dos estressores no perifiton e sua relação com os SE .................................34

Interação do perifiton com os diferentes grupos de SE ..............................................35

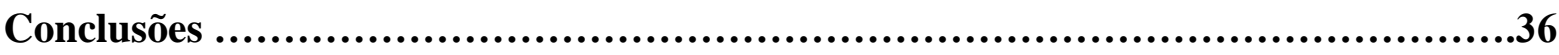

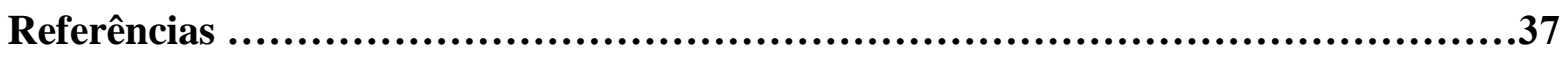

Capítulo 2 - FEASIBILITY OF PERIPHYTON CULTIVATION IN TANKS FOR

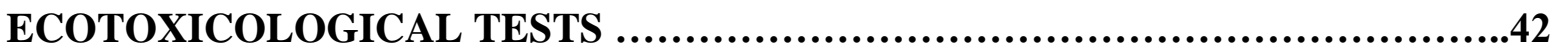

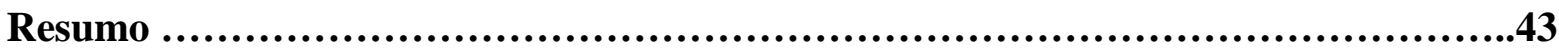

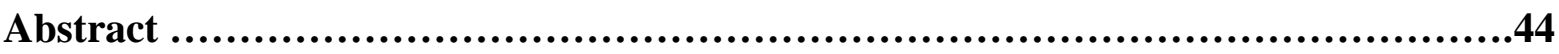

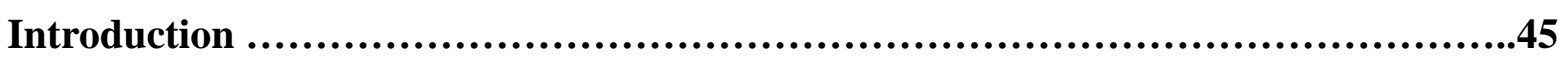

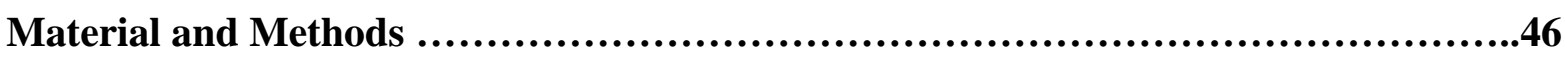

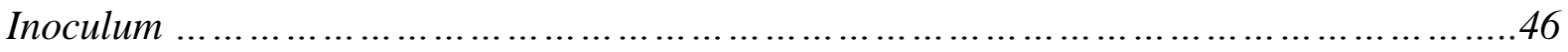


Culture tank and periphyton cultivation .................................................. 47

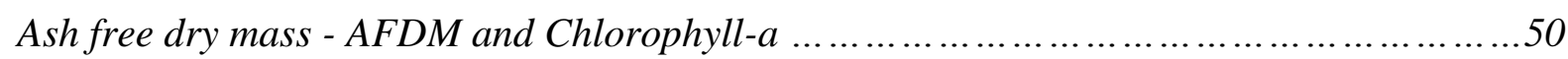

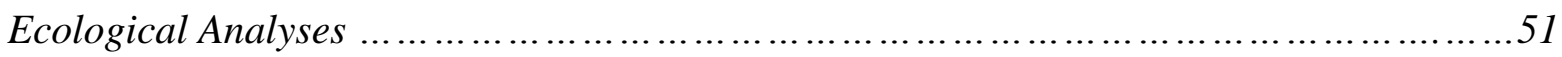

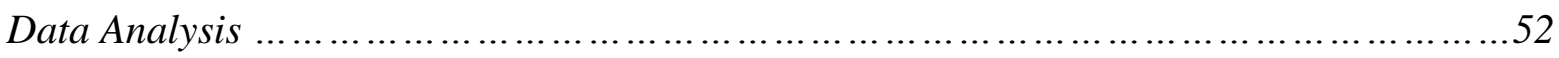

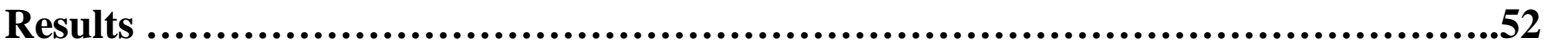

Ash free dry mass - AFDM and Chlorophyll-a ..........................................52

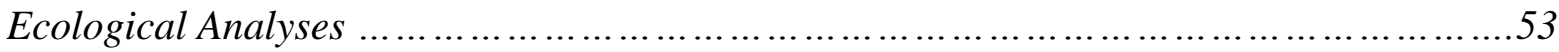

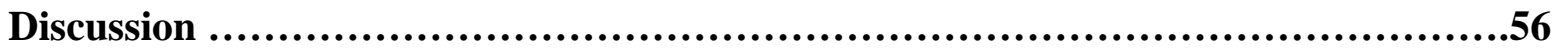

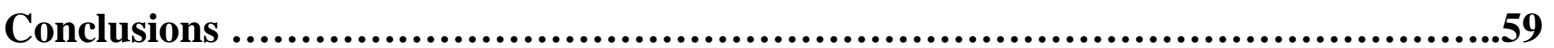

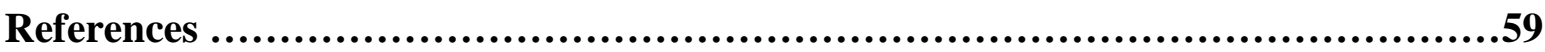

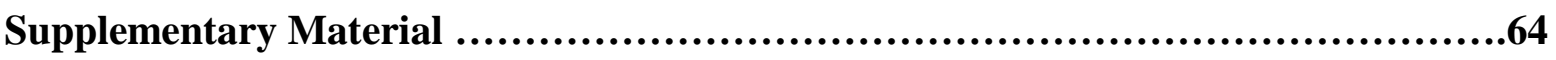

Capítulo 3 - COMMUNITY-LEVEL CHANGES IN PERIPHYTIC BIOFILM CAUSED

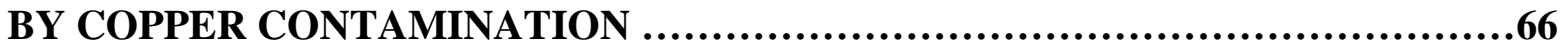

Resumo

Abstract .............................................................................68

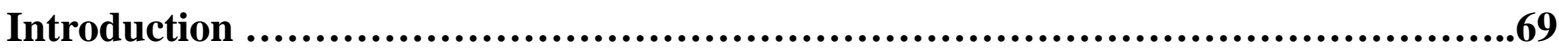

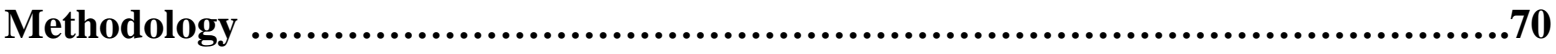

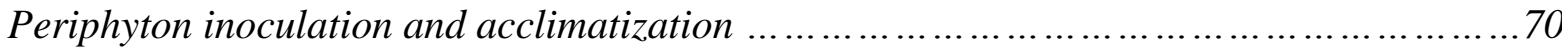

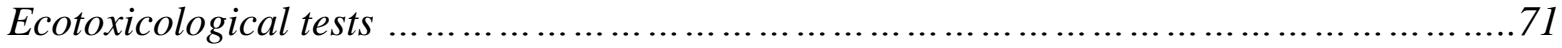

Taxonomic characterization and ecological parameters ....................................71

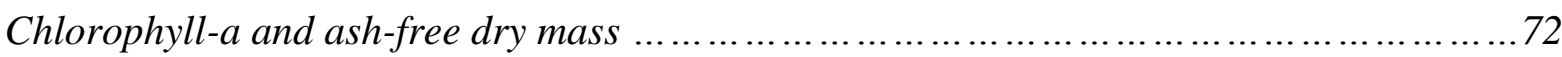

Fluorescence measurements and light saturation curves ................................72

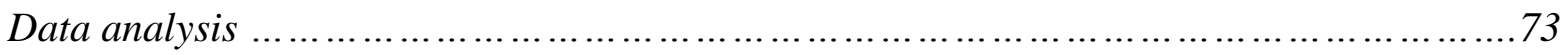

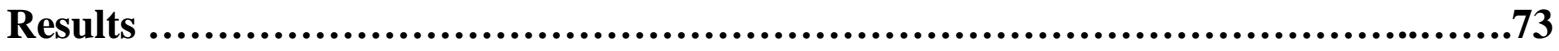

Taxonomic characterization and ecological parameters .................................. 73

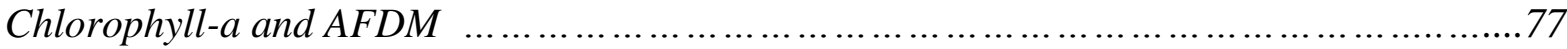

Fluorescence measurements and photosynthetic curves .....................................77

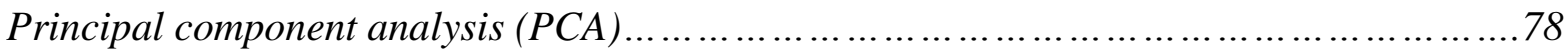

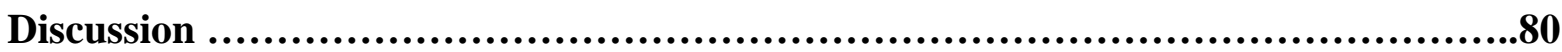

Conclusions ...................................................................85

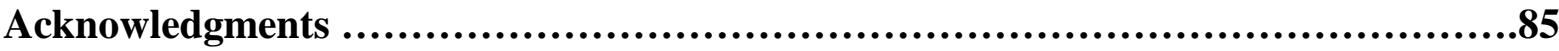

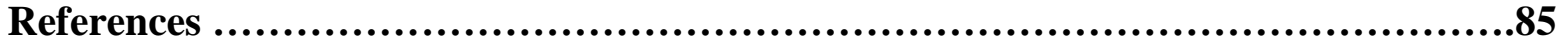


Capítulo 4 - CAFFEINE AS A CONTAMINANT OF PERIPHYTON: ECOLOGICAL CHANGES AND IMPACTS ON PRIMARY PRODUCERS ........................95

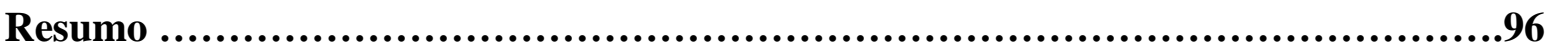

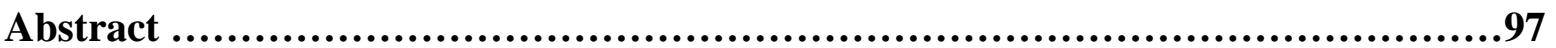

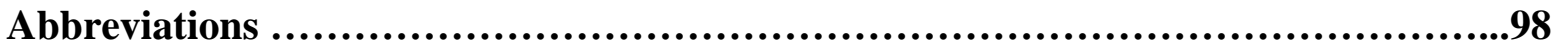

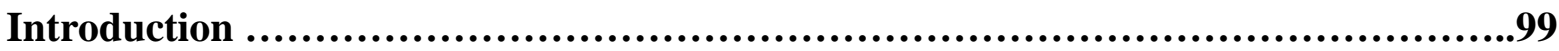

Methodology .........................................................................100

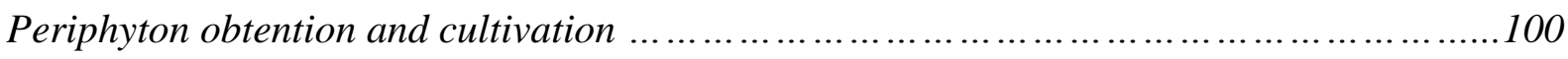

Ecotoxicity test - Experimental design ............................................... 101

Taxonomic characterization and ecological parameters ....................................102

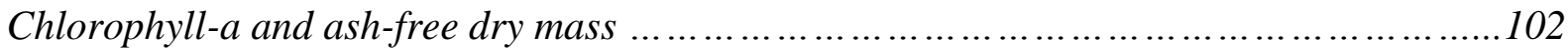

Electron transportation rate and Light saturation curve .....................................103

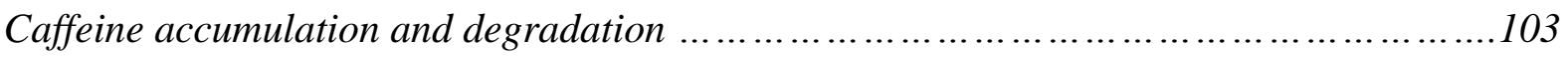

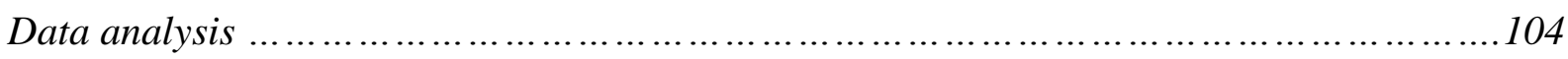

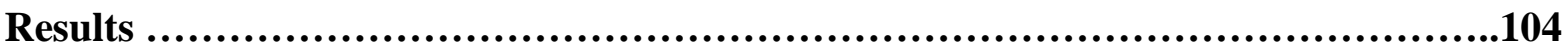

Taxonomic characterization and ecological parameters .................................. 104

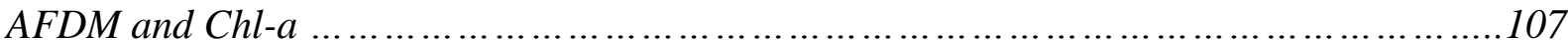

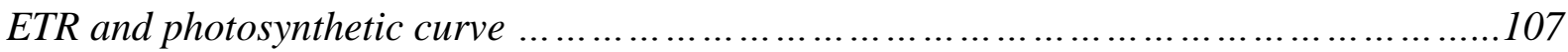

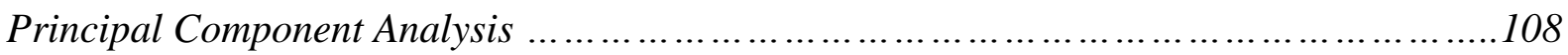

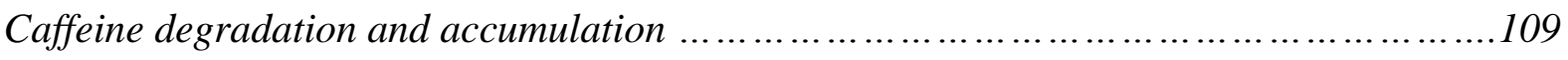

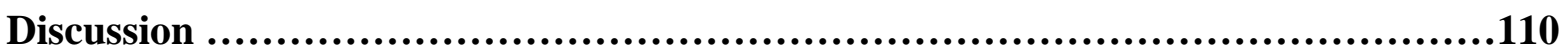

Conclusions .......................................................................113

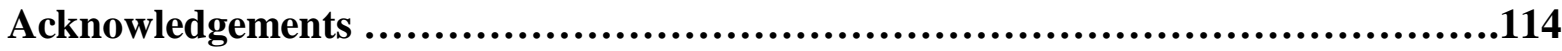

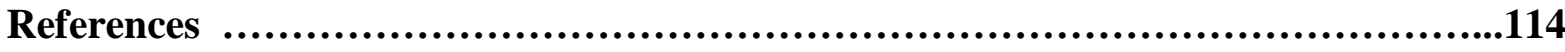

Capítulo 5 - EFFECTS OF A CONTAMINATED RESERVOIR SUPERFICIAL SEDIMENT ON PERIPHYTON: METAL BIOACCUMULATION AND

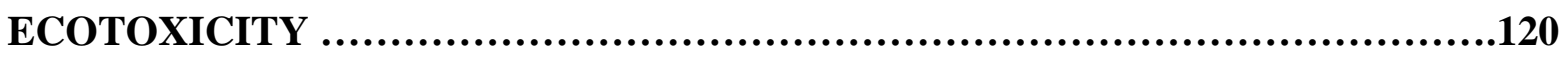

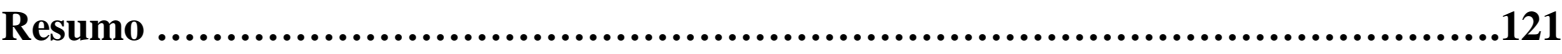

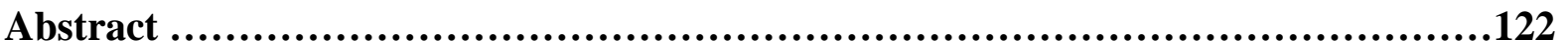




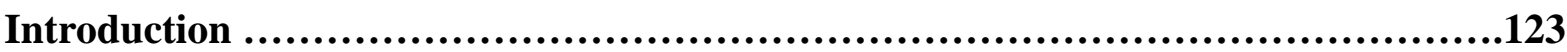

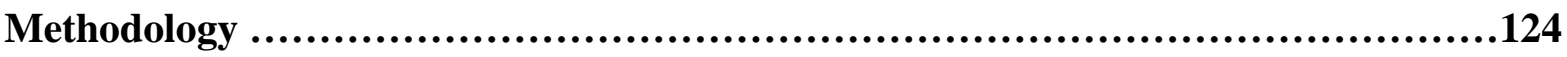

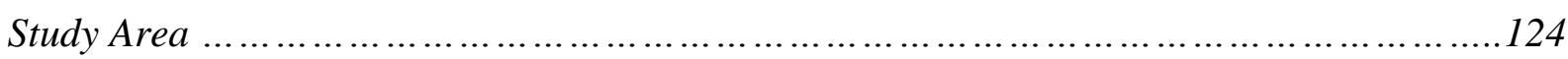

Sampling, processing and characterization of the sediment .............................. 125

Periphyton cultivation for ecotoxicological tests ....................................... 126

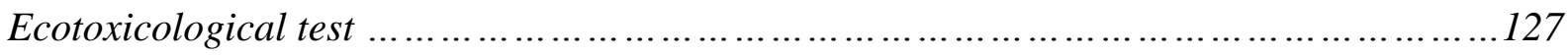

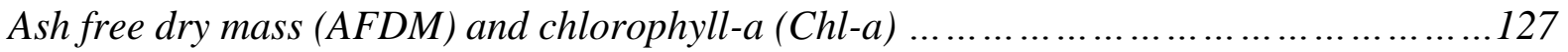

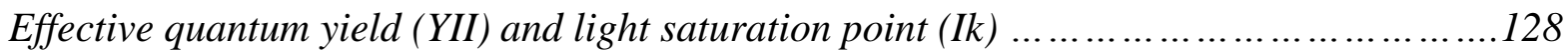

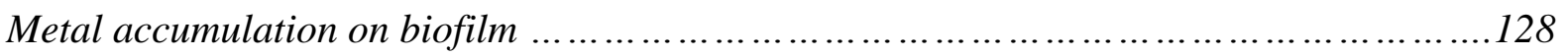

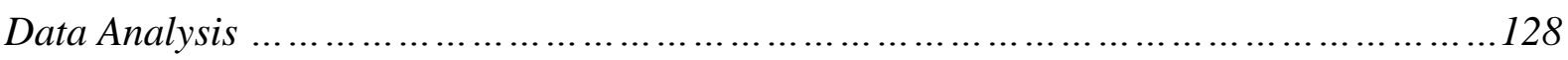

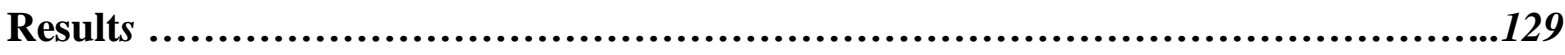

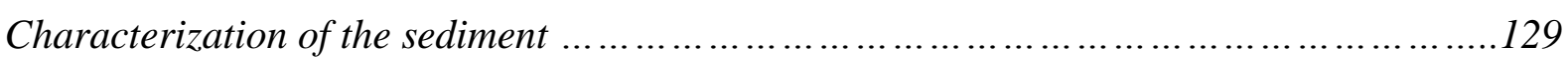

Ash free dry mass (AFDM) and chlorophyll-a $($ Chl-a) ........................................ 129

Effective quantum yield (YII) and light saturation curve ....................................130

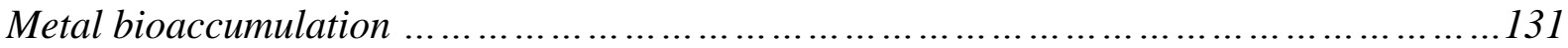

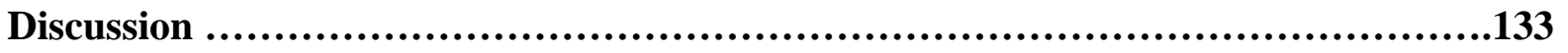

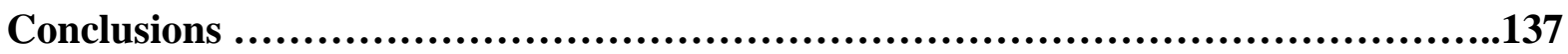

References .....................................................................137

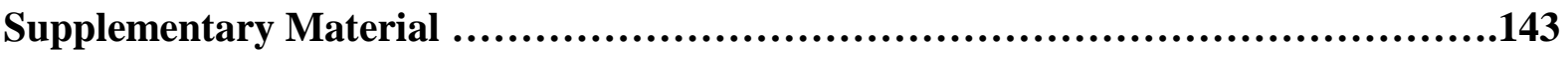

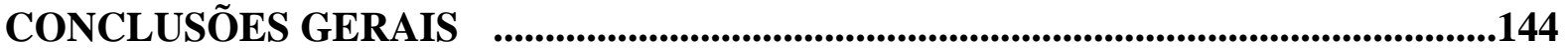




\section{INTRODUÇÃO GERAL}

A água é uma das condições essenciais à vida. Por isso, a proximidade com ela sempre foi essencial ao desenvolvimento da humanidade (MAYS \& ANGELAKIS, 2012). Historicamente, grandes civilizações foram construídas em áreas com grande disponibilidade de água, como os arredores de grandes rios, e na região litorânea (CASARIN \& SANTOS, 2011). Consequentemente, o colapso hídrico numa área, devido a fenômenos climáticos ou antrópicos, também pode levar à extinção de grandes civilizações. Um exemplo foi o caso dos Maias em 950 a.C. (HAUG et al., 2003), onde o desaparecimento é diretamente ligado a um grande período de seca na península de Yucatan. Sendo assim, a água também alcançou um papel espiritual nessas culturas, sendo diretamente ligada à deidades, mitos e práticas religiosas (MAYS \& ANGELAKIS, op cit.).

Já no Neolítico (c. 5700-3200 a.C.) o homem começou a desenvolver a habilidade de controlar o fluxo de água para consumo, irrigação e pecuária, evitando a escassez em períodos de seca (DE FEO et al., 2011). Na China antiga, de acordo com Du \& Koenig (2012), a manutenção do abastecimento de água através de reservatórios já era bem estabelecida durante a dinastia Han (220-280 a.C). No império Romano, construções similares também eram muito encontradas nas cidades, devido à grande demanda por água, a qual vinha de regiões distantes da Trácia e precisava ser armazenada (DE FEO et al., op cit.). Desde então, os reservatórios se desenvolveram tanto em tamanho como em funcionalidades. Além da função inicial de fornecimento hídrico, hoje os reservatórios também possuem a função de navegação, recreação, controle de enchentes, e geração de energia (DU \& KOENIG, 2012; NISHIMURA et al., 2015). Sendo assim, esses ecossistemas complexos criados em parte pelo homem possuem características únicas, uma vez que são ambientes transicionais entre lagos e rios (POMPÊO et al., 2015).

Quando os reservatórios se encontram próximos à área urbana, utiliza-se a denominação "reservatórios urbanos". Essa categoria atualmente engloba grande parte dos reservatórios e possui características relevantes em relação a sua conservação. Devido à proximidade com a atividade antrópica, reservatórios urbanos estão sujeitos a diversas fontes de contaminação como : esgoto, efluentes industriais, resíduos sólidos e combustíveis fósseis (ROSA et al., 2015).

Portanto, políticas de preservação desses ambientes devem ser desenvolvidas tanto no âmbito de monitoramento da qualidade da água, quanto em relação à remediação. Para tal são 
necessárias ferramentas que auxiliem os pesquisadores em relação à medição dos parâmetros físicos e químicos no reservatório, para avaliação das possíveis alterações causadas pela atividade antrópica. Canter et al. (1984), por exemplo, cita as análises físicas e químicas de oxigênio dissolvido, fósforo total, nitrogênio total, $\mathrm{pH}$, condutividade, concentração de metais, demanda biológica de oxigênio, odor, turbidez, sólidos totais, demanda biológica de oxigênio e salinidade. Mas na atualidade há inúmeras outras análises que poderão ser utilizadas para a avaliação da qualidade das águas ou mesmo dos sedimentos, como os complexos Relatórios de Qualidade das Águas Interiores do Estado de São Paulo (COMPANHIA AMBIENTAL DO ESTADO DE SÃO PAULO, 2017), publicados anualmente. Além disso, também são necessários estudos de caráter biológico, avaliando e quantificando os impactos da contaminação nas espécies presentes nos ecossistemas, ou ao menos, em espécies representativas do mesmo (COSTA et al., 2008). Estes estudos podem ser realizados através de amostragens em campo, ou experimentos em laboratório, nos chamados testes ecotoxicológicos. Esses testes avaliam a influência de compostos e condições de crescimento nas populações presentes, ajudando a compreender o potencial de risco ambiental de um contaminante (HOLANDA et al., 2012, COSTA et al., op cit.). Alguns organismos comumente usados em testes ecotoxicológicos ligados à qualidade de água são Drosophila melanogaster (POMPA et al., 2011), Danio rerio (HOLANDA et al., op cit.), Daphnia magna e Lemna minor (FLORÊNCIO et al., 2014), entre outros.

Num reservatório onde há grande riqueza de espécies, e com uma rede trófica extremamente complexa, é interessante se avaliar os efeitos da contaminação a todos os níveis tróficos. No entanto, nem sempre é possível devido à restrições metodológicas (COSTA et al., op cit.). Nesse caso, uma opção é utilizar os produtores como bioindicadores uma vez que estes são o suporte central de toda a biota presente. Se as condições ambientais afetam os produtores, toda a rede trófica será prejudicada (FELISBERTO \& MURAKAMI, 2013), além de afetar inúmeros serviços ecossistêmicos essenciais (NAICHENG et al., 2017). Nos ambientes aquáticos, os produtores primário são principalmente microalgas, presentes no fitoplâncton e no perifíton (YONGHONG, 2016). O fitoplâncton é a parte móvel, presente na coluna d'água e se move involuntariamente com o movimento das correntes, já o perifíton é composto por algas que crescem aderidas ou parcialmente aderidas em substratos presentes no reservatório (NAICHENG et al, 2017). As espécies presentes no perifíton podem ou não diferir em relação àquelas presentes no fitoplâncton, visto que muitas espécies são 
consideradas pertencentes a ambas as comunidades, variando sua posição na coluna d'água em relação às condições de luz e disponibilidade de nutrientes (MARGALEFF, 1998).

A comunidade perifítica é especialmente útil como bioindicador do ambiente, com vantagens em relação ao fitoplâncton e outros indicadores comumente usados. Isso porque o perifíton possui a capacidade de absorver substâncias em sua mucilagem. Como resultado acontece a contaminação em níveis tróficos superiores (CANTONATTI \& LOWE, 2014) após seu consumo por diversos grupos como peixes, artrópodes, gastrópodes (GARDHAN et al., 2015). Essa característica, aliada ao caráter séssil da comunidade na coluna d'água funcionam como um registro químico e ecológico local (SERRA et al., 2011). Isso é observado através da especiação na comunidade, pressionada pelas condições presentes, relativos à disponibilidade de luz, nutrientes e contaminantes, moldando a comunidade e promovendo o desaparecimento de espécies mais frágeis (LAMBERT et al., 2015). Esse processo é chamado PICT - Pollution Induced Community Tolerance - e avalia os efeitos não letais ligados a presença de contaminantes na água gerando diferentes níveis de sensibilidade e tolerância (LAMBERT et al., 2016; ROUCO et al., 2014). Esse processo tem efeito direto sobre a cadeia alimentar, uma vez que no caso do desaparecimento de espécies palatáveis, haverá um dano direto causado pela baixa disponibilidade de alimento para os consumidores primários, principalmente os especialistas (DOWNING et al., 2014). Além disso há o risco de biomagnificação na cadeia trófica, no caso de contaminantes bioacumulativos, ou da potencialização de efeitos tóxicos nos consumidores primários.

Apesar dessa grande importância como bioindicador, ainda há uma lacuna em relação aos estudos envolvendo a manipulação do perifíton em laboratório. Isso ocorre pois ainda existem limitações em relação ao seu cultivo, que dificultam seu uso em testes ecotoxicológicos Para que um teste ecotoxicológico com essa comunidade seja realmente representativo das condições encontradas no ambiente (FORBES \& FORBES, 1994) - nesse caso reservatórios - é necessário que o perifíton possua o máximo de espécies possíveis em comum com o local de estudo. Além disso, testes ecotoxicológicos têm como exigência a capacidade de replicação, ou seja, que os experimentos sejam realizados em repetições para posteriores análises estatísticas (NEWMAN, 2015). Também é necessário que o cultivo seja realizado de forma simplificada, visto que uma metodologia que exija grandes investimentos ou manutenção tornaria o trabalho em grande escala inviável.

Com essa problemática em mente, este trabalho desenvolveu uma metodologia de cultivo de perifíton, desde o processo de captação do inóculo, construção da estrutura de 
cultivo e sua posterior utilização em análises ecotoxicológicas focadas na ecologia de reservatórios. Foi aperfeiçoada a metodologia de cultivo em tanques, de modo que a mesma pudesse ser aplicada em testes de ecotoxicidade respeitando as premissas dessa área. Além da avaliação da eficácia do método em si, o mesmo foi aplicado tanto em diferentes classes de contaminantes isolados, como num sedimento contaminado retirado do reservatório de Guarapiranga (São Paulo, SP).

O presente trabalho se encontra dividido em cinco capítulos, estruturados na forma de artigos científicos, com um deles já publicado, outros já submetidos ou em fase final de redação.

No Capítulo 1, através de uma revisão bibliográfica sistemática, será discutida a importância do perifíton no contexto dos serviços ecossistêmicos. Espera-se clarificar com esse trabalho, a ligação do perifíton em diversos serviços, de modo a embasar ainda mais seu uso como bioindicador em ambientes aquáticos. Será mostrada a relação com os diferentes grupos de serviços, e se o perifíton possui interferência direta ou indireta com os mesmos. Também será avaliado se o perifíton é positiva ou negativamente ligado com determinados serviços . Uma vez que a abordagem de serviços ecossistêmicos é extremamente relevante no contexto atual de elaboração de políticas públicas, esses dados servem como base para a conexão entre trabalhos realizados com o perifíton e serviços ecossistêmicos.

No Capítulo 2 será descrita em detalhes a metodologia de tanques de cultivo desenvolvida neste trabalho. Espera-se mostrar, desde a etapa de inoculação, montagem do tanque do cultivo, processo de colonização e a aplicação da metodologia. Partindo da hipótese que o sistema desenvolvido é capaz de criar um biofilme representativo do ambiente natural, e homogeneamente produzido dentro do tanque, espera-se mostrar a aplicabilidade do mesmo para testes ecotoxicológicos. Também serão avaliados os custos envolvidos na implantação, e quais as vantagens e desvantagens encontradas no método empregado neste trabalho se comparado com outros já largamente utilizados em testes ecotoxicológicos.

No Capítulo 3 a metodologia será aplicada num contaminante de origem inorgânica, o cobre $(\mathrm{Cu})$. Esse contaminante trata-se de um problema recorrente nos reservatórios brasileiros, em especial no Estado de São Paulo, devido às frequentes aplicações de sulfato de cobre como algicida para evitar florações de cianobactérias tóxicas (LEAL et al., 2018). 
Entretanto em excesso, o $\mathrm{Cu}$ acaba impactando outras espécies presentes no reservatório. Por isso o estudo de seu impacto no perifíton é de grande relevância. Neste trabalho foram avaliados as alterações estruturais fisiológicas e biológicas da comunidade após contaminação, e quais as possíveis implicações das mesmas num ecossistema aquático.

No Capítulo 4 a metodologia será aplicada para a avaliação dos efeitos de um outro contaminante também muito frequente nos reservatórios em geral, a cafeína. Uma substância que apesar de ser naturalmente produzida por diversas espécies de plantas, é considerada um contaminante emergente, sinal claro da ação antrópica em ecossistemas aquáticos. Apesar de reconhecidos os efeitos da cafeína em níveis tróficos superiores, os efeitos no perifíton ainda são poucos estudados. Partindo da hipótese que a cafeína é um contaminante comum e frequente em ambientes aquáticos (LÓPEZ-DOVAL et al., 2017), espera-se mostrar as alterações estruturais fisiológicas e biológicas que a sua exposição ao perifíton pode causar. Também foi avaliada sua possível transferência a níveis tróficos superiores via ingestão, visando identificar a bioacumulação desse composto no biofilme perifítico.

No Capítulo 5 foi realizado um teste utilizando o sedimento superficial do reservatório de Guarapiranga, em um ponto altamente contaminado. Após a coleta a caracterização da composição do sedimento, especialmente em relação a presença de metais, o mesmo foi exposto ao perifíton cultivado em laboratório. A hipótese nesse caso é que os diferentes metais presentes no sedimento são acumulados pelo biofilme, em diferentes concentrações de acordo com a afinidade do mesmo pelos contaminantes. Também foram avaliados alterações em indicadores de produção primária, e discutido como isso impactaria o reservatório.

A principal hipótese dessa tese é de que o perifíton produzido através da metodologia de tanques de cultivo é capaz de ser aplicada a testes ecotoxicológicos obtendo resultados satisfatórios e aplicáveis à realidade dos reservatórios. Espera-se mostrar que a metodologia aplicada é de simples aplicação em rotina, e que as mudanças estruturais e biológicas apresentadas no biofilme após a contaminação, são representativas de desequilíbrios ambientais que possam ocorrer em ambientes contaminados. 


\section{Referências Bibliográficas}

CANTER, L.W. River Water Quality Monitoring. 1 ed. Boca Ratón: CRC Press, 1985. 186 p.

CANTONATI, M.; LOWE, R. L. Lake benthic algae: toward an understanding of their ecology. Freshwater Science, Washington, v. 33, n. 2, p. 475-486, 2014. https://doi.org/10.1086/676140

CASARIN, F.; SANTOS, M. Água, o ouro azul: Usos e abusos dos recursos hídricos. 1 ed. Rio de Janeiro: Garamond, 2011. 116 p.

COSTA, C.R.; OLIVI, P.; BOTTA, C.M.R.; ESPÍNDOLA, E.L.G. A toxicidade em ambientes aquáticos: discussão e métodos de avaliação. Química Nova, São Paulo, v. 31, n. 7, p. 1820-1830, 2008.

DE FEO, G.; MAYS, L.W.; ANGELAIS, A.N. Water and Wastewater Management Technologies in the Ancient Greek and Roman Civilizations. In: WILDERER, P. Treatise on Water Science - Water Quality Engineering. Amterdan: Elsevier, 2011, p. 3-22.

DOWNING, A.L.; BROWN, B.L.; LEIBOLD, M.A. Multiple diversity-stability mechanisms enhance population and community stability in aquatic food webs. Ecology, New York, v. 95, n. 1, p. 173-184, 2014. https://doi.org/10.1890/12-1406.1

DU, P.; KOENIG, A. History of water supply in pre modern china. In: MAYS, L.W.; ANGELAKIS, A.N. Evolution of Water Supply Through the Millennia. 1 ed. London: Iwa publishing. 2012, 169-226.

FELISBERTO, S. A.; MURAKAMI, E. A. Papel do Perifíton na ciclagem de nutrientes e na teia trófica. In: SHAWARZBOLD, A.; BURLIGA, A. L.; TORGAN, L. C. (Eds) Ecologia do Perifíton. São Carlos : Rima, 2013, p. 23-44.

FLORÊNCIO, T.; CARRASCHI, P.; CRUZ, C.; SILVA, A.F; MARQUES, A.M.; PITELLI, R.A. Bioindicadores neotropicais de ecotoxicidade e risco ambiental de fármacos de interesse para aquicultura. Boletim do Instituto de Pesca, São Paulo, v. 40, n. 4, p. 569 - 576, 2014.

FORBES, V. E.; FORBES T. L. Ecotoxicology in theory and practice. 1 ed. London: Chapman \& Hall, 1994, 247p.

GARDHAN, S.; CHARITON, A.A.; HOSE, G.C. Direct and indirect effects of coppercontaminated sediments on the functions of model freshwater ecosystems. Ecotoxicology, Berlin, v. 24, n. 1, p. 61-70. https://doi.org/10.1007/s10646-014-1355-y

HAUG, G.H.; GÜNTHER, D.; PETERSON, L.C., SIGMAN, D.M.; HUGHEN, K.A.; AESCHILIMANN, B.Climate and the Collapse of Maya Civilization. Science, Washington, v. 299, n. $5613,2003$. $10.1126 /$ science. 1080444 
HOLANDA, J.N.; MACIEL, A.P.; SANTOS, R.L. Avaliação ecotoxicológica da água de lavagem da purificação de biodiesel de soja metílico utilizando Danio rerio como organismo teste. Boletim do laboratório de hidrobiologia, São Luís, v 25, n. 1, p. 13-20. 2012.

LAMBERT, A.S.; DABRIN, A.; MORIN, S.; GAHOU, J.; FOUQUIER, A.; COQUERY, M.; PESCE, S. Temperature modulates phototrophic periphyton response to chronic copper exposure. Environmental Pollution, Amsterdan, n. 208, v. (pt b), p. 821-829, 2015. https://doi.org/10.1016/j.envpol.2015.11.004.

LAMBERT, A.S.; PESCE, S.; FOUQUIER, A.; GAHOU, J.; COQUERY, M.; DABRIN, A. Improved short-term toxicity test protocol to assess metal tolerance in phototrophic periphyton: toward standardization of PICT approaches. Environmental Science and Pollution Research, Berlin, v. 22, n. 6, p. 4037-4045. 2015. https://doi.org/10.1007/s11356014-3505-4

LEAL， P.R.; MOSCHINI-CARLOS， V.; LÓPEZ-DOVAL， J.C.; CINTRA， J.P.; YAMAMOTO, J.K.; BITTENCOURT, M.D.; SANTOS, R.F.; ABREU, G.C.; POMPÊ, M.L.M. Impact of copper sulfate application at an urban Brazilian reservoir: A geostatistical and ecotoxicological approach, Science of The Total Environment, v. 618, p. 621-634, 2018. https://doi.org/10.1016/j.scitotenv.2017.07.095

LÓPEZ-DOCAL， J.C.; MONTAGNER， C.C.; ALBUQUERQUE， A.F.; MOSCHINICARLOS, V.; UMBUZEIRO, G.; POMPÊO, M. Nutrients, emerging pollutants and pesticides in a tropical urban reservoir: Spatial distributions and risk assessment. Science of the Total Environment, v. 575, p. 2017. https://doi.org/10.1016/j.scitotenv.2016.09.210

MARGALEFF, R. La imprecisa frontera entre el plancton y otros tipos de comunidades. In: IV Congresso Latino-Americano de Ficologia, II Reunião Ibero-Americana de Ficologia e Vii Reunião Brasileira de Ficologia. Anais do IV Congresso Latino-Americano de Ficologia, II Reunião Ibero- Americana de Ficologia e Vii Reunião Brasileira de Ficologia, p. 319-326, 1998.

MAYS, L.W.; ANGELAKIS, A.N. Ancient gods and goddess of water. In:

Evolution of Water Supply Through the Millennia. 1 ed. London: Iwa publishing. 2012 , $1-18$.

NAICHENG, W.; XUHUI, D.; YANG, L.; WANG, C. BAATTRUP-PEDERSENG, A.; RIIS, T. Using river microalgae as indicators for freshwater biomonitoring: Review of published research and future directions. Ecological Indicators, Amsterdan, v. 81, n. 1, p. 124-131, 2017. https://doi.org/10.1016/j.ecolind.2017.05.066

NEWMANN, M.C. Fundamentals of Ecotoxicology: The Science of Pollution. 4 ed. Boca

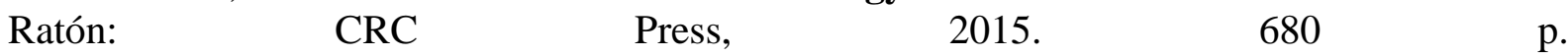

NISHIMURA, P.; MOSCHINI-CARLOS, V., POMPÊO, M.L.M. A Comunidade fitoplanctônica como discriminador da qualidade da água na Represa Billings (São PauloSP). In: POMPÊO, M.L.M.; MOSCHINI-CARLOS, V.; SILVA, S.C.; LÓPEZ-DOVAL, J.C. (Eds) Ecologia de reservatórios e interfaces. I ed. São Paulo: Instituto de Biociências da Universidade de São Paulo. 2015, p. 29-58. 
POMPA, p.; VECCHIO, G.; GALEONE, A.; BRUNETTI, V.; SABELLA, S.; MAIORANO, G.; FALQUI, A.; BERTONI, G.; CINGOLANI, R. In Vivo toxicity assessment of gold nanoparticles in Drosophila melanogaster.Nano Research, Pequim, v. 4, n. 4, pp 405-413, 2011.

POMPÊO, M.L.M., KAWAMURA, P.; MOSCHINI-CARLOS, V.; SILVA, S.C.; LOBO, F.L.; MEIRELLES, S.T. Heterogeneidade espacial horizontal da qualidade da água no reservatório rio grande, complexo Billings, São Paulo - Brasil. In: POMPÊO, M.L.M.; MOSCHINI-CARLOS, V.; SILVA, S.C.; LÓPEZ-DOVAL, J.C. (Eds) Ecologia de reservatórios e interfaces. 1 ed. São Paulo : Instituto de Biociências da Universidade de São Paulo. 2015, p. 72-81.

ROSA, A.H.; SILVA, A.A.M.J.; MELO, C.A.; MOSCHINI-CARLOS, V.; GUANDIQUE, M.E.G.; FRACETO, L.F.; LOURENÇO, R.W. Diagnóstico ambiental e avaliação do uso e ocupação do solo visando a sustentabilidade da represa de Ituparanga, importante área da bacia do médio tietê. In POMPÊO, M.L.M.; MOSCHINI-CARLOS, V.; SILVA, S.C.; LÓPEZ-DOVAL, J.C. (Eds) Ecologia de reservatórios e interfaces. 1 ed. São Paulo: Instituto de Biociências da Universidade de São Paulo. 2015. p. 212-231.

ROUCO, M.; LÓPEZ-RODAS, V.; GONZALEZ, R. HUERTAS, I.E.; GARCÍA-SANCHÉZ, M.J.; FLORES-MOYA, A.; COSTAS, E. The limit of the genetic adaptation to copper in freshwater phytoplankton. Oecologia, Berlin, v. 175, n.4, p. 1179-1188. 2014. https://doi.org/10.1007/s00442-014-2963-1

SERRA, A.; CORCOLL, N.; GUASCH, H. Cooper acumullation and toxicity in fluvial periphyton: The influence of exposal history. Chemosphere, Amsterdam, v. 74, n. 5, p. 633 641. 2011.

YONGHONG, W. Periphyton: Functions and Application in Environmental Remediation. 1 ed. Amsterdam: Elsevier, 2016. 434 p. 


\title{
Capítulo 1
}

\section{O PERIFÍTON E SEU PAPEL COMO PRESTADOR E INDICADOR DA QUALIDADE DE SERVIÇOS ECOSSISTÊMICOS}

\author{
Sousa, M.L. ${ }^{1}$ \\ ${ }^{1}$ Laboratório de Limnologia, Departamento de Ecologia, Instituto de Biociências - \\ Universidade de São Paulo.
}

*Trabalho apresentado na forma de apresentação oral e publicado como trabalho completo nos anais do XVI Simpósio da Pós Graduação em Ciências da Engenharia Ambiental - EESC, São Carlos - Brasil. 


\section{Resumo}

O perifíton é a comunidade formada principalmente por microalgas, bactérias e fungos, formando um biofilme preso á um substrato. Exerce diversas funções nos ecossistemas aquáticos, sendo responsável principalmente por grande parte da produção primária e pela retenção de nutrientes e contaminantes. Devido á isso, ele é responsável por diversos serviços ecossistêmicos, uma área ainda pouco explorada quando se trata de estudos com esse tipo de comunidade, na qual ainda existem várias lacunas. Através de uma revisão bibliográfica sistemática realizada com artigos publicados no período entre 2007 á 2017, procurou-se relacionar o perifíton aos seus serviços ecossistêmicos, e compreender como esses serviços se distribuem entre os diferentes grupos e os fatores diretamente ligados à eles. Observou-se que ainda existem poucos estudos na área e os mesmos se encontram concentrados na América do Norte. Mesmo assim foi possível perceber uma maior participação direta do perifíton nos serviços de regulagem, e suporte, principalmente em relação ao ciclo do N. Já em relação aos serviços culturais foi observada uma relação indireta e negativa, devido às florações de algas causadas pelo despejo de esgoto em rios e lagos.

Palavras-chave: Microalgas, Qualidade da água, Bioindicador, Ecossistemas aquáticos. 


\begin{abstract}
Periphyton is the community composed by microalgae, bacteria and fungi, responsible for a large part of primary production and nutrient retention in aquatic ecosystems. For this reason, periphyton is linked to numerous ecosystem services, even though this approach is still underexplored in studies with this community. In view of this, a systematic literature review using studies between 2007 to 2017 was performed in order to comprehend ecosystem services relationship with periphyton, and how these studies are performed and distributed around the world. It was observed if the periphytic community had positive or negative impacts in specific kinds of services, and which possible factors could lead to it. The results were that the most of the data are concentrated in North America, in field or laboratory studies. Approaches like temporal or spatial were rare. Periphyton was positively linked to regulating and supporting services, due to its role in biomass production and nitrogen cycle. However, when it comes to cultural services, the relationship was negative mainly because of algae blooms, caused by sewage and effluent discharge. This way, periphyton has a good potential as a tool for evaluating ecosystem services, and more studies in this area are expected in the next years.
\end{abstract}

Keywords: Microalgae, Water quality, Bioindicator, Water ecosystems. 


\section{Introdução}

A importância do perifíton para o funcionamento dos ecossistemas aquáticos tem sido estudada desde o início do século XX (BURLIGA \& SCHWARZBOLD, 2013). Trata-se da comunidade composta por microalgas, bactérias, fungos e algumas espécies associadas de zooplâncton que formam um biofilme e vivem aderidas sobre um substrato (BOERO et al, 1996, STEVENSON \& BAHLS, 1999). Esse biofilme juntamente com o fitoplâncton é responsável por considerável parte da produção primária, uma vez que é rico em espécies palatáveis (YONGHONG, 2016). Outra característica importante do biofilme é que ele retém nutrientes, influenciando assim os ciclos biogeoquímicos dentro da coluna d'água e do sedimento (CANTONATTI \& LOWE, 2014). Entretanto essa mesma característica torna o biofilme suscetível ao acúmulo de contaminantes, que podem causar danos tanto ao próprio biofilme como nos níveis superiores da cadeia trófica (FELISBERTO \& MURAKAMI, 2013).

Segundo Wingard \& Lorenz (2014), o perifíton é capaz de produzir respostas rápidas e complexas acerca de problemas ambientais, sendo indicado para a avaliação de questões amplas, como nesse caso. O grupo das diatomáceas presente no perifíton é um conhecido bioindicador da qualidade de ambientes aquáticos (SMUCKER et al., 2013). Entretanto em ocasiões de desequilíbrio da comunidade, a maior dominância de cianobactérias pode fazer com que o biofilme se torne problemático para diversas funções presentes nos ecossistemas aquáticos (BOYER et al., 2009). Sendo assim o biofilme é um ótimo indicador do funcionamento de rios, lagos e reservatórios, já que sua integridade está ligada à qualidade de diversos serviços ecossistêmicos presentes nesses locais. Segundo Hintz et al. (2017), esses serviços além de importantes para o funcionamento de um ecossistema como um todo, podem ser valorados bilhões de dólares.

O conceito de serviços ecossistêmicos (SE) ou ambientais surgiu na década de 70, sendo aprimorado desde então (GOMÉZ-BAGGETHUN et al., 2010). O tema tem tomado força a partir de 2005 com o relatório da Millennium Ecosystem Assessment (2005), abordando as mudanças causadas pelo ser humano, sua relação com os SE e apontando metas futuras. De uma maneira simples, SE podem ser definidos como componentes da natureza que são direta ou indiretamente utilizados pelo ser humano, gerando bem estar (BOYD \& BANZHAF, 2007). É possível observar mudanças nessa definição de acordo com a evolução e tendências da economia, tornando-o mais ou menos abrangente, como observado por 
Goméz-Baggethun et al. (2010). É importante ressaltar que a valoração dos serviços não se dá apenas do ponto de vista econômico. Atualmente são considerados serviços os processos ligados ao bem-estar como um todo: cultural e psicológicos e biofísico (PASCUAL et al., 2017). Atualmente divide-se os serviços ecossistêmicos em 4 principais grupos de acordo com suas funções: suporte, regulação, provisão ou cultural (BATEMAN, et al., 2014).

O reconhecimento dessas funções nos ecossistemas aquáticos e principalmente no perifíton, é um sinal do aumento das políticas sustentáveis e da preocupação com a preservação do ambiente (DENICOLA \& KELLY, 2015). A comunidade perifítica é afetada por diversos fatores, os quais podem interferir na sua capacidade de prover um determinado serviço direto ou mesmo induzir sua resposta como indicador para um serviço prestado por outro componente do ecossistema. Por exemplo, a introdução de espécies invasoras (REID \& TORRES, 2014), mudanças climáticas (BOULÊTREAU et al, 2012), poluição (ESTEVÉZ et al., 2017) e presença de predadores (STEVENSON et al., 2012). Sendo assim, é importante entender a relação do perifíton com os SE, a quais drivers ele está submetido, e que podem desencadear algum impacto, de acordo com a abordagem descrita por Albert et al. (2016).

Este trabalho visa responder algumas questões pertinentes em relação ao perifíton e sua ligação com os SE's. Pretende-se discutir quais são alguns serviços atribuídos ao perifíton, e como a atividade antrópica impacta esses serviços. Também espera-se mapear onde e como estão sendo desenvolvidos os estudos, qual classe de serviços mais abordada e porquê. Por fim deve-se identificar as possíveis lacunas ainda existentes nessa área, e quais as possíveis motivações para tal, direcionando assim futuros estudos.

\section{Metodologia}

Uma vez definida a questão central da pesquisa, foi realizada uma revisão literária sistemática (SAMPAIO \& MANCINI, 2007; WEHRMEISTER et al., 2011) acerca da comunidade perifítica e sua ligação com o conceito de SE. Para uma melhor organização, o trabalho foi dividido nas etapas de revisão (busca), triagem e análise dos resultados, de modo a gerar o maior número de respostas possível acerca do tema em questão. 


\section{Revisão}

A etapa de revisão consistiu na busca por literatura acerca do tema dentro da base literária ISI Web of Knowledge. Uma vez que o conceito de SE se tornou popular a partir do relatório do Millennium Ecosystem Assessment (2005), a revisão foi realizada no período de junho de 2007 até junho de 2017. Optou-se por utilizar apenas artigos científicos, excluindose capítulos de livros, teses, dissertações, relatórios ou outros tipos de publicações. Foram utilizadas 3 diferentes chaves de pesquisa para a realização da revisão: a) $\mathrm{TS}=(($ periphyton) AND (ecosystem AND service* $)), \mathrm{b}) \mathrm{TS}=(($ stream AND biofilm) AND (ecosystem AND service) ) e c) TS=((alga* AND mat*) AND (ecosystem AND service*)). Os termos foram procurados tanto nos títulos, palavras chave quanto resumo dos manuscritos. Artigos que apareceram em mais de uma pesquisa foram contabilizados uma única vez. Os artigos então foram salvos em texto integral para a etapa posterior de triagem.

\section{Triagem}

Na etapa de triagem os artigos obtidos foram lidos para avaliar sua real adequação ao tema e capacidade de responder às perguntas propostas pela pesquisa. Foram considerados válidos trabalhos enquadrados em pelo menos uma das exigências abaixo:

a) O trabalho possui como objeto de estudo o tema desta pesquisa, mesmo que não como foco principal?

b) O trabalho lida com termos muito próximos, facilmente ligados ao tema desta pesquisa a partir da leitura do próprio texto, sem a necessidade de bibliografia complementar?

c) O trabalho não lida diretamente com o tema desta pesquisa, mas cita-a em determinados pontos (como nos resultados e discussão por exemplo).

Deste modo, procurou-se garantir que os trabalhos utilizados fossem realmente relevantes à discussão, evitando-se artigos da área que só citam o tema pontualmente, sem desenvolvê-lo em nenhum momento e, portanto, incapazes de responder às perguntas levantadas. Após selecionados os artigos que atendiam aos critérios desejados, foi realizada a etapa de análise. 


\section{Análise dos dados}

As informações contidas nos trabalhos foram separadas em diferentes categorias, de modo a facilitar a visualização de como a informação foi produzida nessa última década. Os trabalhos foram categorizados por: ano de publicação, periódicos e local de onde o estudo foi realizado. Quanto ao delineamento experimental, foi avaliado em qual ambiente os trabalhos foram desenvolvidos, qual a abordagem metodológica utilizada e se o perifíton foi o objeto de estudo ou um indicador ambiental. Já os SE's mencionados foram organizados em relação ao grupo (suporte, regulação, provisão ou cultural), quantificados o número de trabalhos onde os serviços foram mencionados e qual a relação do perifíton com esses serviços, se direta (como um prestador) ou indireta (como um indicador ou influenciador). Foi considerada também a natureza da interação, se positiva, negativa

\section{Resultados e discussão}

\section{Resultados}

Excluindo-se os artigos que apareceram duplicadamente em mais de uma chave de pesquisa, obteve-se um total de 73 artigos na revisão inicial. Após a triagem esse número caiu para 22, os quais foram considerados para análise dos resultados (Figura 1a).

Apesar do período avaliado abranger desde o ano de 2007, as primeiras publicações sobre o tema surgiram em 2011, atingindo seu ápice em 2014 com 7 publicações. Até junho de 2017 houveram 4 publicações, sendo este o segundo melhor resultado no período avaliado. Quanto ao local onde os estudos foram realizados (Figura 1b), observou-se grande enfoque na região da América do Norte, principalmente em relação aos Estados Unidos, enquanto regiões como América Central e África tiveram apenas um estudo cada, e nenhum realizado no continente asiático. Um mesmo trabalho poderia tratar de mais de uma localidade, por isso o número total de citações na Figura 1b ultrapassa o número total de artigos utilizados nesta revisão. No caso de artigos de revisão sobre o perifíton, estes foram considerados sem localização específica, a não ser que o trabalho houvesse deixado claro a importância desta. 
Figura 1 Distribuição temporal (a) e espacial (b) dos estudos publicados relacionados à comunidade perifítica e SE's.
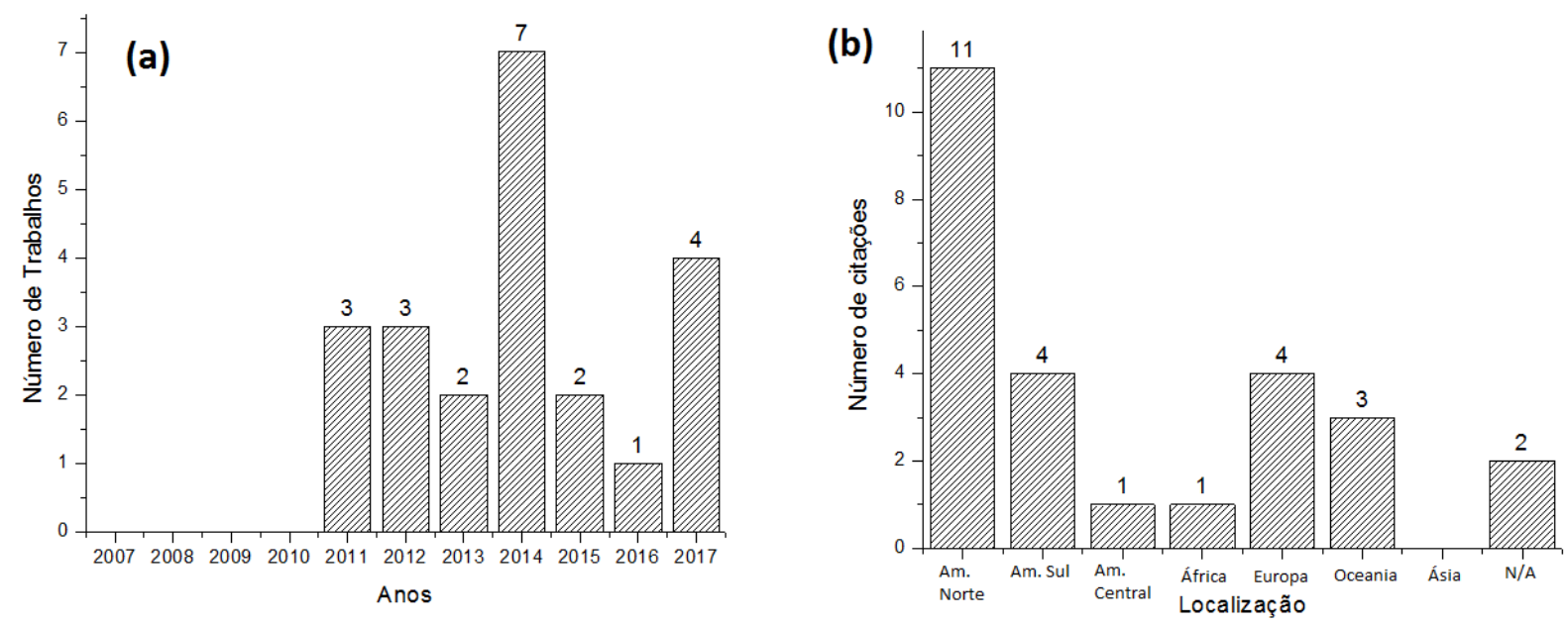

O número de periódicos onde os trabalhos foram publicados foi alto, um total de 17 para os 22 artigos. Apenas três periódicos apresentaram mais de uma publicação sobre o tema no período: Science of the Total Environment (2), Ecological Indicators (2) e Freshwater Science (3).

A maioria dos trabalhos abordou o perifíton de rios, seguidamente do de lagos (Figura 2a). Ecossistemas aquáticos urbanos, como lagos artificiais e rios canalizados também foram abordados.

Figura 2 Distribuição metodológica nos trabalhos levantados. (a) Em relação ao ambiente, (b) Em relação ao tipo de abordagem e (c) ao tipo de substrato utilizado.

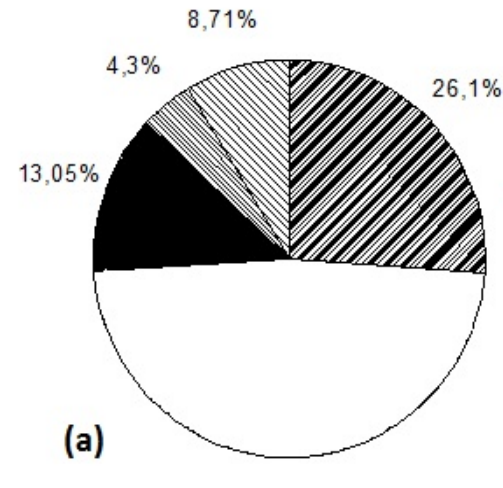

$47,85 \%$

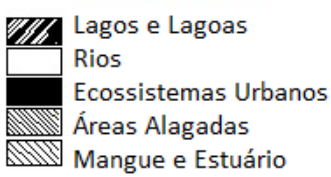

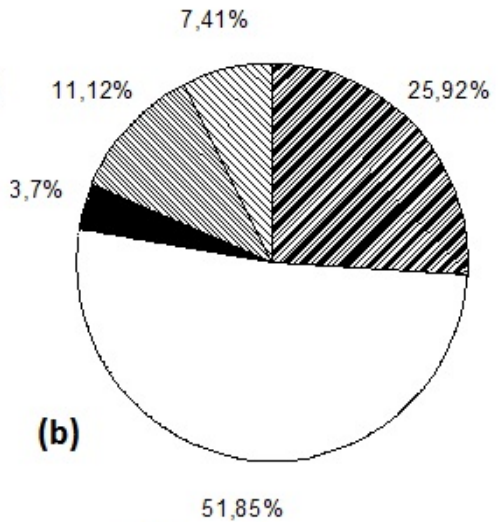

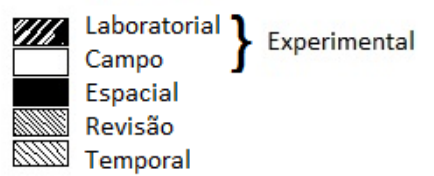

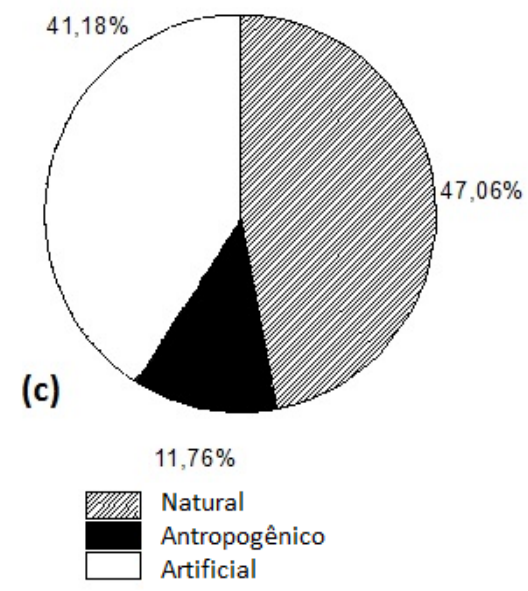


Quanto a abordagem metodológica dos trabalhos (Figura 2b), em sua maioria foram realizados trabalhos de campo ou experimentais em laboratório. Cerca de $23 \%$ dos trabalhos optaram por utilizar mais de uma abordagem (como por exemplo experimentos de campo aliados os estudos em laboratório). Abordagens de espacialidade ou temporalidade foram pouco utilizadas. A comunidade perifítica foi objeto de estudo principal em $40 \%$ dos estudos, enquanto serviu como indicadora para o objeto principal em $60 \%$ deles. Em relação ao substrato utilizado para obtenção do perifíton, foi observada uma leve preferência em estudos utilizando substratos naturais como rochas, se comparados com os cultivos em substratos artificiais como lâminas de vidro e mesocosmos. Alguns estudos entretanto foram realizados no que se considerou substratos antropogênicos, como o biofilme de estações de tratamento de água e esgoto, porém em bem menor quantidade que os tipos anteriores.

Os SE's citados nos trabalhos, que de alguma forma foram atribuídos ou pelo menos relacionados à comunidade perifítica, foram organizados na Tabela 1. Foi respeitada a maneira como os serviços foram citados nos trabalhos, por isso alguns serviços podem se sobrepor no caso de serviços/ processos primários e secundários (produção de alimento e produção primária, retenção de nutrientes e qualidade da água). Apenas quando os serviços eram muito similares (como ciclo de nitrogênio e desnitrificação), estes foram agrupados dentro do mesmo serviço, para melhor visualização dos resultados. A relação entre o perifíton e o respectivo serviço foi avaliada de acordo com o descrito no trabalho: positiva (+), no caso da presença do perifíton ser benéfica ao serviço citado, negativa (-), no caso do perifíton prejudicar ou causar desserviço; e neutra (.), quando a influência do perifíton pode ser tanto positiva ou negativa, dependendo então de fatores ambientais externos. 
Tabela 1 SE's ligados à comunidade perifítica

\begin{tabular}{|c|c|c|c|}
\hline Serviço Ecossistêmico & Influência & Interação & Citações \\
\hline \multicolumn{4}{|l|}{$\underline{\text { Serviços de Provisão }}$} \\
\hline $\begin{array}{c}\text { Produção de Comida } \\
\text { (Peixes e outros organismos) }\end{array}$ & I & · & 4 \\
\hline Produção de Energia & $\mathrm{I}$ & - & 1 \\
\hline \multicolumn{4}{|l|}{$\underline{\text { Serviços de Regulagem }}$} \\
\hline Manutenção da Qualidade de Água & $\mathrm{D} / \mathrm{I}$ & . & 5 \\
\hline Remoção de Patógenos & I & + & 1 \\
\hline Dinâmica de Sedimentos & $\mathrm{D} / \mathrm{I}$ & + & 2 \\
\hline Retenção de Nutrientes & $\mathrm{D} / \mathrm{I}$ & + & 3 \\
\hline Processamento de Matéria Orgânica & $\mathrm{D} / \mathrm{I}$ & . & 2 \\
\hline $\begin{array}{l}\text { Prevenção da Ressuspensão } \\
\text { de Toxinas }\end{array}$ & $\mathrm{D}$ & + & 1 \\
\hline \multicolumn{4}{|l|}{$\underline{\text { Serviços de Suporte }}$} \\
\hline Ciclagem de $\mathrm{N}$ & $\mathrm{D}$ & + & 7 \\
\hline Ciclagem de $\mathrm{C}$ & $\mathrm{D} / \mathrm{I}$ & + & 3 \\
\hline Formação de Solo & I & + & 1 \\
\hline Produção Primária & $\mathrm{D}$ & + & 7 \\
\hline Ciclagem de Nutrientes & $\mathrm{D} / \mathrm{I}$ & + & 2 \\
\hline \multicolumn{4}{|l|}{$\underline{\text { Serviços Culturais }}$} \\
\hline Pesca recreacional & I & . & 2 \\
\hline Recreação Aquática & $\mathrm{D}$ & - & 3 \\
\hline Valor Estético & $\mathrm{D}$ & - & 2 \\
\hline Valor Imobiliário & $\mathrm{D}$ & - & 1 \\
\hline Senso de Lugar & $\mathrm{D}$ & - & 1 \\
\hline
\end{tabular}

Onde:

- Influência: Significa se o perifíton é direta (D) ou indiretamente (I) ligado ao serviço, ou ambos (D/I).

- Interação: + interação apenas positiva com o serviço, - interação apenas negativa com o serviço e • a interação pode ser positiva ou negativa, dependendo da comunidade perifítica em questão e fatores ambientais.

- Citações: número de trabalhos onde a interação é mencionada. 


\section{Discussão}

\section{Natureza dos dados e distribuição espacial dos estudos}

Em relação às publicações, observou-se que elas ocorreram apenas a partir de 2011, seis anos após a publicação do Millennium Ecosystem Assessment (2005), onde o conceito de serviços ecossistêmicos foi consolidado. Ainda assim, observou-se que poucos estudos relacionando os serviços ecossistêmicos ao perifíton foram publicadas. Apesar da limitada quantidade de artigos levantada, foi possível observar certos padrões em relação á esse tema, e que podem explicar o motivo para tal falta de publicações. Cantonatti e Lowe (2014) e Kelly (2013) alertam para o fato de que apesar da reconhecida importância do perifíton para o funcionamento dos ecossistemas aquáticos, a abundância de dados ainda é baixa, se comparado com

Quanto a distribuição dos estudos, foi observado que trabalhos envolvendo ciclo do $\mathrm{N}$ foram mais presentes na América do Norte, área que também concentrou a maior parte dos estudos de forma geral. Já os estudos envolvendo serviços culturais foram desenvolvidos na Austrália e América do Sul, sendo que a abordagem dos trabalhos mostrou a presença de serviços explicitamente fornecidos pelo perifíton, principalmente nos grupos de regulagem e suporte, como em Beaulieau et al (2014), Peterson et al (2011) e Cochero et al (2013).

Os serviços associados aos rios e lagos foram mais estudados, em detrimento de outros ambientes. Estevez et al. (2017) aponta que um dos motivos é a área representada por esses ambientes quando comparado, por exemplo, com áreas de nascentes em montanhas. Apesar de oferecerem diversos SE, as áreas de nascentes representam uma porcentagem pequena da área total de uma paisagem, sendo, portanto, preteridas em estudos. Vários trabalhos também usaram o perifíton como um indicador da qualidade de serviços fornecidos por outras estruturas dos ecossistemas (como rios, macrófitas, etc.), como observado em Walthan et al (2014), Shaefer et al (2012), Sanchéz et al (2017). Foram utilizadas principalmente abordagens de campo e experimentais em laboratório. Apesar dessas serem abordagens convencionais em estudos do perifíton (SCHNECK, 2013), do ponto de vista dos SE, metodologias temporais e espaciais são muito essenciais, uma vez que se pode entender melhor a dimensão e alcance do serviço estudado e os processos relacionados (BERRET et al., 2015). Isso prejudica a abordagem dos Se's, que acabam sendo citados apenas de maneira indireta em muitos trabalhos, por falta de dados temporais e espaciais precisos. 
Normalmente a porção autotrófica do perifíton é a mais estudada (SCHNECK, 2013), entretanto os estudos focando ecossistemas urbanos e áreas adjacentes trouxeram abordagens mais diferenciadas ao assunto, principalmente em relação aos serviços ligados a porção bacteriana do perifiton. No caso dos rios canalizados e lagos adjacentes aos loteamentos, o papel do perifíton na manutenção do ciclo de N, através dos processos de desnitrificação e retenção de $\mathrm{N}$, remoção de patógenos e qualidade de água se torna muito claro. Beaulieau et al (2014) mostrou que a canalização afetou a capacidade do perifíton em reter $\mathrm{N}$, gerando zonas com baixa produção e diversidade, e zonas com alta concentração de NO3 a jusante, eutrofizadas, com mau cheiro e má qualidade de água. Nesse caso a poluição foi responsável tanto por afetar a capacidade do perifíton em oferecer um serviço (retenção de N), quanto em prover desserviços (LYYTIMÄKI, 2014), como má qualidade de água por meio das toxinas das cianobactérias e mal cheiro. Já Beuteu e Larson (2015) apontam o perifíton bacteriano como responsável pela manutenção da qualidade da água, quando presente em filtros biológicos de pedra.

Enquanto isso, nas áreas afastadas de centros urbanos, o foco volta-se quase que exclusivamente para o perifíton autotrófico, uma vez que os serviços de produção primária/ produção de biomassa se tornam mais importantes. O principal caso citado é em relação ao perifíton como base da cadeia alimentar ligada a atividade pesqueira (HINTZ et al 2017, KLOSKOWSKI 2011). A única exceção foi o estudo de Shaefer et al (2012), estudando o efeito de pesticidas na perda de SE em rios, utilizando o perifíton bacteriano e fúngico como indicador. Uma vez que este também foi o único trabalho abordando identificação e quantificação de fungos, isso mostra uma lacuna no que diz respeito aos serviços oferecidos / influenciados por esse grupo em especial, segundo já apontado por Beaulieau et al (2014).

\section{Influência dos estressores no perifíton e sua relação com os $S E$}

Foi observado que as comunidades perifíticas possuem uma alta capacidade de adaptação a contaminação, sem afetar o serviço de produção primária, porém isso não necessariamente significa que outros serviços estejam intactos. Espécies mais adaptadas à nova condição podem possuir menor ou nenhum desempenho em determinado serviço, logo, 
este será afetado mesmo que a produção primária não o seja (REID \& TORRES, 2016). Outra consequência pode ser a perda das interações ecológicas necessárias para o desenvolvimento do serviço, também perdidas com a troca de espécies (REISINGER et al, 2011). Segundo Shaefer et al (2012), concentrações capazes de matar algumas espécies de algas isoladas em laboratório, não o fazem em campo, devido exatamente às interações presentes na comunidade.

Portanto é necessário entender qual o serviço deseja-se estudar primeiramente, para se determinar como a comunidade perifítica deve ser abordada. Geiser et al (2015), aponta para o fato que pode haver dificuldade em discernir entre os serviços realizados pelo perifíton em si, ou por outros componentes do ecossistema ao qual o perifíton está inserido. Isso torna a quantificação dos seus serviços mais complicada. Segundo DeNicola e Kelly (2014), a dificuldade está na quantificação do perifíton bem como de seus estressores, pois apesar da relação direta entre o dano e o serviço ecossistêmico, o esforço exigido para obtenção dos dados é grande, devido á necessidade de estudos em campo e experimentais. Nessa revisão, esse tipo de abordagem contou com cerca de $76 \%$ dos trabalhos.

\section{Interação do perifíton com os diferentes grupos de SE}

$\mathrm{O}$ ciclo do $\mathrm{N}$ e produção primária foram os serviços mais apontados como promovidos diretamente pelo perifíton (cada um respectivamente com 7 citações). No caso do ciclo do $\mathrm{N}$, principalmente no que diz respeito a etapa de desnitrificação, foram realizados diversos estudos avaliando o impacto de espécies invasoras (REID \& TORRES, 2016), e principalmente o grande aporte de esgoto doméstico (WHALTAN et al., 2014), nos ecossistemas aquáticos, e como isso pode moldar e afetar a dinâmica do $\mathrm{N}$ nesses locais. Em geral o perifíton se relacionou positivamente com os serviços de regulagem (qualidade da água, dinâmica de sedimentos, remoção de patógenos, processamento da matéria orgânica) e suporte (ciclos de $\mathrm{N}$ e $\mathrm{C}$, formação do solo, produção primária). Os serviços de provisão foram os menos citados, uma vez que sua relação com o perifíton é indireta. Entretanto sua relação foi neutra/negativa. No caso da produção de biomassa a relação pode ser positiva (como fonte de alimento para peixes e outras espécies de interesse), quanto negativa (florações de algas tóxicas e não palatáveis). Na produção de energia a relação é negativa uma vez que florações estão ligadas á perda da capacidade de produção em reservatórios 
No caso dos serviços culturais foi observado que o perifíton se relacionou em geral negativamente (Tabela 1). Isso ocorre, pois, as florações de algas causam um grande impacto estético em corpos d'água, bem como afetam sua qualidade (SHAEFER et al, 2012). Um ambiente com alta densidade de microalgas é impróprio para banho afetando a recreação (HINTZ et al, 2017), potencialmente tóxico, possui mal cheiro e inclusive está ligado á desvalorização imobiliária (WALTHAN et al, 2014). Os serviços culturais são assim diretamente impactados pelo desequilíbrio nas comunidades perifíticas e fitoplanctônicas, o que pode ser classificado como um desserviço ambiental (LYYTIMÄKI, 2014). A situação também pode ser interpretada como um caso de trade-off ecossistêmico (DENG et al, 2016), com o serviço de recolhimento de esgoto pela água sendo superdimensionado, em detrimento dos serviços culturais oferecidos pelo corpo d'água limpo. Nessa abordagem então o perifíton passaria a ser um indicador dessa situação de troca. Outro caso de de trade-off relacionado a serviços culturais pode ser identificado no trabalho de Kloskowski (2011), onde a criação de carpas jovens (serviço de provisão) causou o aumento da concentração de cianobactérias tóxicas, prejudicando as atividades recreativas nos lagos (serviço cultural). Portanto mostra-se que o perifíton se relaciona de diversas maneiras com os SE. O biofilme é um importante indicador da qualidade e reflexo das ações antrópicas sobre os serviços ligados á ele. Isso mostra a necessidade de maiores estudos que supram as lacunas ainda existentes em relação a determinados grupos e localidades, tornando possível sua preservação e manutenção dos

SE's

aquáticos.

\section{Conclusões}

O perifíton está relacionado direta ou indiretamente com diversos SE's, como foi mostrado. Entretanto ainda existe uma importante lacuna na produção científica, uma vez que os estudos atuais estão focados principalmente na América do Norte, e áreas como a Ásia, África e América Central contam com poucos ou nenhum estudo. Além disso estudos envolvendo a porção fúngica do perifíton são escassos. A capacidade do perifíton em prover e indicar serviços de um ecossistema está intimamente ligada com sua composição, uma vez que a troca de espécies dentro do biofilme afeta seu desempenho dentro de um serviço específico. Portanto é importante compreender as relações entre as espécies dentro do 
perifíton e como elas se relacionam com os serviços de interesse.

Foi observado que o perifíton se relacionou positivamente com os serviços de regulagem e suporte e negativamente com serviços culturais. Nesse caso a relação negativa se deu devido principalmente ao lançamento de esgotos domésticos responsáveis pelo surgimento de florações de cianobactérias tóxicas, afetando a qualidade e aparência da água, gerando situações de trade-off com outros serviços fornecidos pelos corpos d'água. O serviço mais citado provido pelo perifíton foi sua relação com o Ciclo do $\mathrm{N}$, que foi foco de vários dos trabalhos apresentados, sendo uma função essencial ligada á qualidade dos ecossistemas aquáticos. Portanto conclui-se que o estudo do perifíton é uma área importante a ser considerada quando avaliados os SE's de ambientes aquáticos, ainda que sejam necessários mais estudos melhor distribuídos pelo mundo.

\section{Referências}

ALBERT, C.; GALLER, C.; HERMES, J.; NEUENDORF, F.; HAARENA, C.; LOVETT. A. Applying ecosystem services indicators in landscape planning and management: The ES-inPlanning framework. Ecological Indicators, v. 61, n. 1, p. 100-113, 2016. https://doi.org/10.1016/j.ecolind.2015.03.029

BATEMAN, I. J.; MACE, G. M.; FEZZI, C.; ATKINSON, G.; TURNER, R. K. Economic analysis for ecosystem services assessments. In: NINAN, K. N. (Eds) Valuing Ecosystem Services: Methodological Issues and Case Studies. Cheltenham: Edgard Elgar Publishing, 2014 ,

BEAULIEU, J. J.; MAYER, P. M.; KAUSHAL, S. S.; PENNINO, M. J. Effects of urban stream burial on organic matter dynamics and reach scale nitrate retention. Biogeochemistry, Heidelberg, v.121, n. 1, p.107-126, 2014. https://doi.org/10.1007/s10533-014-9971-4

BENNETT, E. M.; CRAMER, W.; BEGOSSI, A.; CUNDIL, G.; DIAZ, S.; EGOH, B. N.; GEIJZENDORFFER, I. R.; KRUG, C. B.; LAVOREL, S.; LAZOS, H.; LEBEL, L.; MARTIN-LOPEZ, B.; MEYFROIDT, P.; MOONEY, H. A.; NEL, J.L; PASCUA, U.; PAYET, K.; HARGUINDEGUY, P.; PETERSON, G.D.; PRIEUR-RICHARD, A.; REYERS, B.; ROEBELING, P.; SEPPELT, R.; SOLAN, M.; TSCHAKERT, P.; TSCHARNTKE, T.; TURNER, B. L.; VERBUNG, P. H.; VIGLIZZO, E. F.; WHITE, P. C. L.; WOODWARD, G. Linking biodiversity, ecosystem services, and human well-being: three challenges for designing research for sustainability. Current Opinion in Environmental Sustainability, v.14, n. 1, p. 76-85, 2015.

BEUTEL, M.W.; LARSON, L. Pathogen removal from urban pond outflow using rock biofilters. Ecological Engineering, v. 78, n. 1, p. 72-78, 2015. 
https://doi.org/10.1016/j.ecoleng.2014.05.001

BOERO, F.; BELMONTE, G.; FANELLI, G.; PIRAINO, S.; RUBINO, F. The continuity of living matter and the discontinuities of its constituents: do plankton and benthos really exist? Tree, Maryland Heighs, v. 11, n. 4, p. 177-180, 1996. https://doi.org/10.1016/01695347(96)20007-2

BOULÊTREAU, S.; SALVO, E.; LYAUTEY, E.; MASTRORILLO, S.; GARABETIAN, F. Temperature dependence of denitrification in phototrophic river biofilms. Science of the $\begin{array}{lllllll}\text { Total Environment, } & \text { v. } 416, \quad \text { n. } & 1, \quad \text { p. } 323-328, & \end{array}$ https://doi.org/10.1016/j.scitotenv.2011.11.066

BOYD, J.; BANZHAF, S. What are ecosystems services? The need for standardized environmental accounting units. Ecological Economics, v. 63, n. 2-3, p. 616-626, 2007. https://doi.org/10.1016/j.ecolecon.2007.01.002

BOYER, J. N.; KELBLE, C. R.; ORTNER, P. B.; RUDNICK, D. T. Phytoplankton bloom status: Chlorophyll a biomass as an indicator of water quality condition in the southern estuaries of Florida, USA. Ecological Indicators, v. 9, n. 6, p. s56-s67, 2009. https://doi.org/10.1016/j.ecolind.2008.11.013

BURLIGA, A. L.; SCHWARZBOLD, A. Perifíton: diversidade taxonômica e ecológica. In: SHAWARZBOLD, A.; BURLIGA, A. L.; TORGAN, L. C. (Orgs) Ecologia do Perifíton. São Carlos : Rima, 2013, p.

CANTONATI, M.; LOWE, R. L. Lake benthic algae: toward an understanding of their ecology. Freshwater Science, Chicago, v. 33, n. 2, p. 475-486, 2014. https://doi.org/10.1086/676140

COCHERO, J.; ROMANI, A. M.; GÓMEZ, N. Delayed response of microbial epipelic biofilm to nutrient addition in a Pampean stream. Aquatic Microbial ecology, v. 69, n. 2, p. $145-155$,

2013.

https://doi.org/10.3354/ame01630

DENG, X.; LI, Z.; GIBSON, J. A review on trade-off analysis on ecosystems services for sustainable land-use management. Journal of Geographic Sciences, v. 26, n. 7, p. 953-968, 2016.

https://doi.org/10.1007/s11442-016-1309-9

DENICOLA, D. M.; KELLY, M. Role of periphyton in ecological assessment of lakes. Freshwater Science, Washington, v. 32, n. 2, p. 619-638, 2015. https://doi.org/10.1086/676117

ESTEVEZ, E.; RODRIGUEZ-CASTILLO, T.; ÁLVAREZ-CÁBRIA, M.; PEÑAS, F. J.; GONZALÉZ-FERRERAS, A. M.; LEZCANO, M.; BARQUÍN, J. Analysis of structural and functional indicators for assessing the health state of mountain streams. Ecological Indicators, v. 72, n. 1, p. 553-564, 2017. https://doi.org/10.1016/j.ecolind.2016.08.052

FELISBERTO, S. A.; MURAKAMI, E. A. Papel do Perifíton na ciclagem de nutrientes e na teia trófica. In: SHAWARZBOLD, A.; BURLIGA, A. L.; TORGAN, L. C. (Orgs) Ecologia do Perifíton. São Carlos : Rima, 2013, p. 23-44. 
GAISER, E. E.; ANDERSON, E. P.; CASTAÑEDA-MOYA, E.; COLLADO-VIDES, L.; FOUEQUREAN, J. W.; HEIHAUS, M. R.; JAFFE, R.; LAGOMASINO, D.; OEHM, N. J.; PRICE, R. M.; RIVERA-MONROY, V. H.; CHOWDRURY, R. R. TROXLER, T. G. New perspectives on an iconic landscape from comparative international long-term ecological research. Ecosphere, Washington, v. 6, n. 10, p. 1-18, 2015. https://doi.org/10.1890/ES1400388.1

GOMÉZ-BAGGETHUN, E.; GROOT, R.; LOMAS, P. L.; MONTES, C. The history of ecosystems services in economic theory and pratice: from early notions to Market and payment schemes. Ecological Economics, v. 69, n. 1, p. 1209-1218, 2010. https://doi.org/10.1016/j.ecolecon.2009.11.007

HINTZ, W. D.; MATTES, B. M.; SCHLER, M. S.; JONES, K. S. STOLER, A. B.; LIND, L.; RELYEA, R. A. Salinization triggers a trophic cascade in experimental freshwater communities with varying food-chain length. Ecological Applications, v. 27, n. 3, p. 833844, 2017. https://doi.org/10.1002/eap.1487

KELLY, M. Data rich, information poor? Phytobenthos assessment and the Water Framework Directive. European Journal of Phycology, London, v. 48, n. 1, p. 437-450, 2013. https://doi.org/10.1080/09670262.2013.852694

KLOSKOWSKI, J. Differential effects of age-structured common carp (Cyprinus carpio) stocks on pond invertebrate communities: implications for recreational and wildlife use of farm ponds. Aquaculture Integrated, v. 19, n. 1, p. 1151-1164, 2011. https://doi.org/10.1007/s10499-011-9435-y

LYYTIMAKI, J. Ecosystems disservices: embrace the catchword. Ecosystem Services, v. 12, n. $1, \quad$ p. $136, \quad 2015 . \quad$ https://doi.org/10.1016/j.ecoser.2014.11.008

MILLENIUM ECOSYSTEM ASSESSMENT. Ecosystems and Human Well-Being: $\begin{array}{llll}\text { Synthesis. } & \text { Washington } & \text { DC: }\end{array}$

PASCUAL, U.; BAVANERA, P.; DÍAZ, S.; PATAKI, G.; ROTH, E.; STENSEKE, M.; WATSON, R. T.; BESSANE, E. B.; ISLAR, M.; KELEMEN, E.; MARIS, V.; QUAAS, M.; SUBRAMANIAN, S. M.; WITMER, H.; ADLAR, A.; AHN, S.; AL-HAFEDH, Y. S.; AMANKWAH, E.; ASAH, S. T.; BERRY, P.; BILGIN, A.; BRESLOW, S. J.; BULLOCK, C.; CACCERES, D.; DALY-HASSEN, H.; FIGUEROA, E.; GOLDEN, C. D.; GOMÉZBAGGETHUN, E.; GONZALÉZ-GIMENÉZ, D.; HOUDET, J.; KEUNE, J.; KUMAR, R.; MA, K.; MAY, P. H.; MEAD, A.; O'FARREL, P.; PANDIT, R.; PENGUE, W.; PICHISMADRUGA, R.; POPA, F.; PRESTON, S.; PACHECO-BALANZA, D.; SAARIKOSKI, E.; STRSSBURG, B. B.; BELT, M.; VERMA, M.; VICKSON, F.; YAGI, N. Valuing nature's contribution to people: the IPBES approach. Current opinion in Environmental Sustainability, v. 26, p. 7-16, 2017. https://doi.org/10.1016/j.cosust.2016.12.006

PETERSON, C. G.; DALEY, A. D.; PECHAUER, S. M.; KALSCHEUR, K. N. SULLIVAN, M. J.; KUFTA, S. L.; ROJAS, M.; GRAY, K. A.; KELLY, J. J. Development of associations between microalgae and denitrifying bacteria in streams of contrasting anthropogenic influence. Microbiology Ecology, Oxford, v. 77, n. 3, p. 477-492, 2011. https://doi.org/10.1111/j.1574-6941.2011.01131.x 
REID, B.; TORRES, R. Didymosphenia geminata invasion in South America: Ecosystem impacts and potential biogeochemical state change in Patagonian rivers. Acta Oecologica, v. 54, n. 1 , p. 101-109, 2014. https://doi.org/10.1016/j.actao.2013.05.003

REISINGER, A. J.; PRESUMA, D. L.; IDO, K. B.; DODDS, W. K. Direct and indirect effects of central stoneroller (Campostoma anomalum) on mesocosm recovery following a flood: can macroconsumers affect denitrification? Journal of the North American Benthological Society, Chicago, v. 30, n. 3, p.840-852, 2011. https://doi.org/10.1899/10169.1

SAMPAIO, R. F.; MANCINI, M. C. Estudos de revisão: um guia para síntese criteriosa da evidência científica. Revista Brasileira de Fisioterapia, São Carlos, v. 11, n. 1, p. 83-89, 2007. http://dx.doi.org/10.1590/S1413-35552007000100013

SANCHÉZ, M. L.; RODRIGUÉZ, P.; TORREMORELL, A. M. IZAGUIRREI, I.; PIZARRO, H. Phytoplankton and Periphyton Primary Production in Clear and Turbid Shallow Lakes: Influence of the Light Environment on the Interactions between these Communities. Wetlands, v. 37, n. 1, p. 67-77, 2017. https://doi.org/10.1007/s13157-0160840-x

SCHAFER, R. B.; BUNDSCHUH, M.; ROUCH, D. A.; SZOCS, E.; OHE, P. C.; PETTIGROVE, V.; SCHULZ, R.; NUGEGODA, D. KEFFORD, B. J. Effects of pesticide toxicity, salinity and other environmental variables on selected ecosystem functions in streams and the relevance for ecosystem services. Science of the Total Environment, v. 415, p. 6978 ,

2012. https://doi.org/10.1016/j.scitotenv.2011.05.063

SCHNECK, F. Tendências e lacunas dos estudos sobre perifíton de ambientes aquáticos continentais no Brasil: Análise cienciométrica. In: SHAWARZBOLD, A.; BURLIGA, A. L.; TORGAN, L. C. (Orgs) Ecologia do Perifíton. São Carlos : Rima, 2013, p. 7-22.

SILVA, J. S. V.; CARVAlHO, J. R. P.; SANTOS, R. F.; FELGUEIRAS, C. A. Espacialização da homogeneidade e heterogeneidade do meio biofísico para planejamento ambiental utilizando análise multivariada. Anais do $1^{\mathbf{0}}$ simpósio de geotecnologias no Pantanal. Embrapa Informática e Agropecuária/INPE, Campo Grande, v.1, n. 1, p. 691 699 , 2006.

SMUCKER, N. J.; DETENBECK, N. E.; MORRISON, A. C. Diatom responses to watershed development and potential moderating effects of near-stream forest and wetland cover. Freshwater Science, Chicago, v. 32, p. 230-249, 2013. https://doi.org/10.1899/11-171.1

STEVENSSON, C. J.; BADEN, S.; MOKSEN, P.; ABERG, P. Temporal mismatches in predator-herbivore abundance control algal blooms in nutrient-enriched seagrass ecosystems. Marine Ecology Progress Series, v. 471, n. 1, p. 61-71, 2012. https://doi.org/10.3354/meps10014

STEVENSON, R. J.; BAHLS, L. L. Periphyton Protocols. In: BARBOUR, M. T..; GERRITSEN, J.; SNYDER, B. D.; STRIBLING, J. B. Eds. Rapid bioassessment protocols for use in streams and wadeable rivers: periphyton, benthic macroinvertebrates and fish. Office of Water, Washington DC: Environmental Protection Agency, 1999, EPA 841-B- 
99-002.

WALTHAN, N. J.; REICHELT-BRUSHETT, A.; MCCANN, D. EYRE, B. D. Water and sediment quality, nutrient biochemistry and pollution loads in an urban freshwater lake: balancing human and ecological services. Environmental Sciences Processes \& Impacts, v. 16 , n. 1, p. 2804-2813, 2014. https://doi.org/10.1039/c4em00243a.

WEHRMEISTER, F. C.; KNORST, M.; JARDIM, J. R.; MACEDO, S. E. C.; NOAL, R. B.; MARTINEZ-MESA, J.; GONZALÉZ, D. A.; DUMITH, S. C.; MAIA, M. F.; HALLAL, P. C.; MENEZES, A. M. B. Programas de reabilitação pulmonar em pacientes com DPOC. Jornal Brasileiro de Pneumologia, Brasília, v. 37, n. 1, p. 544-555, 2011.

WINGARD, G.L.; LORENZ, J.J. Integrated conceptual ecological model and habitat indices for the southwest Florida coastal wetlands. Ecological Indicators, v. 44, n. 1, p. 92-107, 2014.

https://doi.org/10.1016/j.ecolind.2014.01.007

YONGHONG, W. Periphyton: Functions and Application in Environmental Remediation. 


\title{
Capítulo 2
}

\section{FEASIBILITY OF PERIPHYTON CULTIVATION IN TANKS FOR ECOTOXICOLOGICAL TESTS}

\author{
Mariana L. Sousa ${ }^{1}{ }^{*}$; Fungyi Chow ${ }^{2}$; Marcelo L.M. Pompêo ${ }^{1}$ \\ ${ }^{1}$ Laboratory of Limnology, Department of Ecology, Institute of Bioscience, University of São \\ Paulo. \\ ${ }^{2}$ Laboratory of Marine Algae "Édison José de Paula", Department of Botany, Institute of \\ Bioscience, University of São Paulo.
}

*Trabalho atualmente submetido ao periódico Fottea. 


\section{Resumo}

A relevância do perifíton como bioindicador para ecossistemas aquáticos tem sido estudada por décadas, com resultados positivos. Essa comunidade é altamente representativa para as cadeias alimentares aquáticas, sendo assim, alterações em sua composição afetam diretamente o ecossistema. Com isto em mente, o desenvolvimento e melhoramento de metodologias que visam o cultivo de perifíton em laboratório é importante quando se trata de testes ecotoxicológicos e estudos biotecnológicos. O cultivo laboratorial proporciona controle das variáveis físicas e químicas responsáveis pelo crescimento do perifíton, levando assim á uma melhor replicabilidade dos experimentos. Várias metodologias têm sido aplicadas com sucesso em estudos envolvendo a comunidade perifítica. Entretanto, ainda existem problemas relativos à manutenção e custos de implementação, assim como a qualidade do biofilme perifítico resultante. Assim, esse estudo apresenta uma metodologia para cultivo laboratorial do perifíton através de tanques de cultivo, os quais são facilmente replicáveis e possuem custo inferior se comparado a outras metodologias. Os resultados mostraram que os tanques foram capazes de produzir uma camada homogênea de perifíton após 21 dias de cultivo, pronto para uso em testes ecotoxicológicos. Em relação à qualidade do perifíton cultivado, foi observada menor menor biomassa e concentração de clorofila-a se comparado com o inóculo, além de alterações ecológicas como menor riqueza de espécies e diversidade. Chlorophyceae foi o grupo mais afetado pela adaptação às condições laboratoriais. Mesmo assim, todos os grupos algais presentes no inóculo foram identificados no perifíton cultivado, formando uma comunidade representativa do ambiente original.

Palavras-chave: bioindicador; ecologia aquática; métodos; microalga; tanques de cultivo. 


\begin{abstract}
The importance of periphyton as a bioindicator for aquatic ecosystems has been studied for several decades, with positive results. This community is highly representative for aquatic food chains, therefore, alterations in its composition directly affect the ecosystem. Considering this, the development and enhancement of methodologies aiming at periphyton cultivation in the laboratory is important when it comes to ecotoxicity and biotechnological studies. Laboratory cultivation provides control of physical and chemical variables responsible for periphyton growth, leading to replicability of experiments. Several methodologies have already been used and successfully applied in periphyton studies. However, there are still problems involving maintenance and implementation costs, as well as regarding the quality of the periphyton cultivated. This study presents a methodology for periphyton cultivation in the laboratory through culture tanks, which are easily replicable and cost less than other methods. Results showed that the tanks provide an homogeneous layer of periphyton, ready to be used after 21 days of growth. When it comes to the quality of the periphyton cultivated, less biomass and chlorophyll-a were observed when compared to the initial inoculum, and structural alterations lowered species richness and diversity. Chlorophyceae was the most affected group in the adaptation to laboratory conditions. Nevertheless, all the algal groups of the inoculum were present in cultivated periphyton, forming a representative community.
\end{abstract}

Keywords: bioindicator; culture tanks; microalgae; methods; water ecology; water quality. 


\section{Introduction}

Periphyton is an important bioindicator for water ecosystems, as the effects generated by contamination of this community are very representative for the environment (WALKER, 2014). The periphyton community is described as a complex community, formed by several taxonomic groups such as: bacteria, fungi, zooplankton species, and mostly algae (YONGHONG, 2016). Therefore, considering the high abundance of species and consequently the ecological relationships between them, periphyton allows us to identify synergistic effects of contamination (WINGARD \& LORENZ, 2014).

The important role of periphyton in aquatic ecosystems has served as motivation for research that uses this community. Along with phytoplankton, periphyton composes the base of aquatic food chains (GAISER et al., 2015), reaching up to $80 \%$ of total primary production in some environments (MAHDY et al., 2014). Due to this, contamination of this community directly affects the entire food chain. This occurs because periphyton is able to retain substances within its mucilage, including nutrients as well as contaminants (FELISBERTO \& MURAKAMI, 2013). These substances can then be transferred to other trophic levels through predation. The most important predators of periphyton are small fishes, snails, larvae and some zooplankton species (LIESS \& HILLEBRAND, 2004).

Initially, most studies involving periphyton were performed in field conditions, aiming at environmental and biotechnological applications related to removing pollutants from water (KASEAANO \& SIMS, 2014). Nowadays, this approach is still very important, especially considering taxonomic (SCHNECK, 2013), ecosystem functioning (TLILI et al., 2016) and food chain studies (PENNUTO et al., 2018). However, field studies are unable to control variables such as temperature, nutrients and oxygenation, which prevents replication: an essential factor for ecotoxicology (NEWMAN, 2015). When considering biotechnological applications for satisfactory results, it is necessary to know the total biomass involved in the operation, as well as the species present (KASEAANO \& SIMS, 2014). Therefore, methodologies for cultivation of periphyton in the laboratory were developed to solve these needs, such as: mesocosms, nutrient diffusion substrates, bioreactors, artificial streams, and culture tanks.

Cultivation in mesocosms and nutrient diffusing substrates are largely used for toxicity tests (HOMMEN et al., 2016), as well as studies that manipulate culture conditions (FERRAGUT et al., 2013; KAZANJIAN et al., 2018) and radiation exposure (NAVARRO et 
al., 2008). For biodegradation essays, bioreactors are more commonly used since they strictly control culture variables, even though such conditions are far from natural (GROSS et al., 2015).

On the other hand, artificial streams are considered closer to natural environments, since they simulate the effects of water flow. Such technique is used principally for experiments regarding periphyton metabolism (CORCOLL et al., 2015), such as ecotoxicity tests (VAL et al., 2016), functioning of aquatic ecosystems and ecological interactions (GUASH \& SERRA, 2009). However, like the bioreactors, artificial streams are quite expensive, making it difficult to apply on larger scales. Besides, these methodologies can require a complex handling and maintenance (CORCOLL et al., 2015; UGWU, et al., 2008).

Another option is culture tanks. After colonization using an inoculum from a lake or river, it is possible to cultivate a complex biofilm in the laboratory with high replicability capacity (SCHMITT-JANSEN et al., 2016). This methodology is useful in ecotoxicological tests (BERE et al., 2012), bioremediation essays (SHABBIER et al., 2017), and biomass production for fish consumption (CAVALCANTE et al., 2017).

In this study, we propose a method for periphyton cultivation in the laboratory for ecotoxicological or biotechnological tests. By using culture tanks we expected to obtain an homogeneous biofilm, which should contain all the algal groups of the inoculum, and a similar biomass weight. Also, the biofilm produced should be easily replicable, or enough to be divided in samples and applied to tests, ensuring an statistical analysis.

The periphyton cultivated was compared to the original inoculum to identify differences between them, and determine its suitability as bioindicator in ecotoxicological tests. The final price of culture tanks compared to other methodologies is also presented. At the end, we present how the methodology of culture tanks is financially viable and easily replicable in laboratory.

\section{Material and Methods}

Inoculum

Before laboratorial cultivation began, it was necessary to obtain the biofilm to be used as inoculum in culture tanks. We used the biofilm obtained from a lake at the Universidade de 
São Paulo (2333'55"S 4643'51"W), with no external contamination sources. Polipropilen discs of $154 \mathrm{~cm}^{2}$ that were vertically disposed in the water column were used as artificial substrate based on the proposal by Schwarzbold (2013) and Schmitt-Jansen et al. (2016). Polipropilen was chosen over more common materials such as glass due to its flexibility, preventing the loss of material by the fauna or weather conditions. Previous tests using glass as artificial substrate in the lake resulted in broken disks, which could both harm the species in the lake and delay the tests schedule. After 21 days of exposition (TORGAN et al., 2013), the biofilm that developed on the disks was removed using a soft brush and deionized water, and then transferred to the laboratory. Part of this inoculum was separated for posterior ecological and biological analysis for comparison with the cultivated biofilm. Images of the inoculum are available in Supplementary Material.

\section{Culture tank and periphyton cultivation}

The $70 \times 40 \times 30 \mathrm{~cm}$ tank was made of glass, filled to $50 \mathrm{~L}$ with culture medium, and kept on a stand. The culture medium used for periphyton development was L.C. Oligo (ASSOCIAÇÃO BRASILEIRA DE NORMAS TÉCNICAS, 2018), adapted (without Ferric citrate pentahydrate). This medium simulates an oligotrophic environment with little interaction with contaminants, and is commonly used in ecotoxicological protocols. It was composed by seven stock solutions made of deionized water added with the compounds (Table 1) and autoclaved. Then, these stock solutions were kept in refrigerator up to three months, and mixed together with deionized water to form L.C. Oligo when necessary. 
Table 1 Composition of L.C. Oligo medium and stock solutions (ASSOCIAÇÃO BRASILEIRA DE NORMAS TÉCNICAS, 2018 - adapted)

\begin{tabular}{lll}
\hline $\begin{array}{l}\text { Stock } \\
\text { Solution }\end{array}$ & Compound & $\begin{array}{l}\text { Final concentration / } \\
\text { of LC Oligo }\end{array}$ \\
\hline $\mathbf{1}$ & Calcium Nitrate tetrahydrate & $40 \mathrm{mg}$ \\
\hline $\mathbf{2}$ & Potassium nitrate & $100 \mathrm{mg}$ \\
\hline $\mathbf{3}$ & Magnesium sulfate heptahydrate & $30 \mathrm{mg}$ \\
\hline $\mathbf{4}$ & Dibasic potassium phosphate & $40 \mathrm{mg}$ \\
\hline $\mathbf{5}$ & Copper sulphate pentahydrate & $0.015 \mathrm{mg}$ \\
\cline { 2 - 3 } & $\begin{array}{l}\text { Ammonium molybdate } \\
\text { tetrahydrate }\end{array}$ & $0.03 \mathrm{mg}$ \\
\cline { 2 - 3 } & Zinc Sulphate heptahydrate & $0.03 \mathrm{mg}$ \\
\cline { 2 - 3 } & Cobalt chloride hexahydrate & $0.03 \mathrm{mg}$ \\
\cline { 2 - 3 } & Manganese nitrate tetrahydrate & $0.03 \mathrm{mg}$ \\
\cline { 2 - 3 } & Boric acid & $3 \mathrm{mg}$ \\
\hline $\mathbf{6}$ & Iron chloride hexahydrate & $0.62 \mathrm{mg}$ \\
\cline { 2 - 3 } & Iron sulphate heptahydrate & $0.62 \mathrm{mg}$ \\
\hline $\mathbf{7}$ & Sodium bicarbonate & $15 \mathrm{mg}$ \\
\hline
\end{tabular}

The walls of the tank were covered in black EVA to prevent contact with exterior light, since illumination was controlled and provided by $16 \mathrm{~W}$ fluorescent lamps in photoperiods of $12 \mathrm{~h}$. Oxygenation and water circulation were provided through 4 pumps of (model s2000, Boyu), attached to air curtain aerators. Temperature was kept at $26^{\circ} \mathrm{C}$ using a thermostat (model At-100, Atmam).

Inside the tank, the artificial substrate used for periphyton growth, in this case glass slides, were vertically placed using supports made of polystyrene and basalt stones. Each glass slide measured $2.6 \times 7.5 \mathrm{~cm}$, and a total of 112 glass slides could be placed in the tank at the same time. Unlike the lake, the tank was not exposed to weather and fauna conditions, so glass could be used. In order to avoid effects related to different rugosity of the substrates (glass and polipropilen), glass slides were sanded. Images from the tank and artificial substrates are available in Supplementary Material. 
The cultivation step lasted from 14 to 21 days, depending on periphyton development. According to Torgan et al. (2013), this period of time is enough for the growth of a structurally developed biofilm.

Every week, the culture media lost by evaporation was replaced and inoculation was redone. At the end of this period the glass slides were removed from the tank for analysis. Biofilm was removed using a soft brush and deionized water, then separated into different samples for ecological and biological analysis to evaluate the homogeneity inside the culture tank and quality of the biofilm. The whole process, from inoculum to sample obtention (including the step with an ecotoxicological test ), is described in Figure 1. 
Figure 1: Methodology of periphyton cultivation and obtention

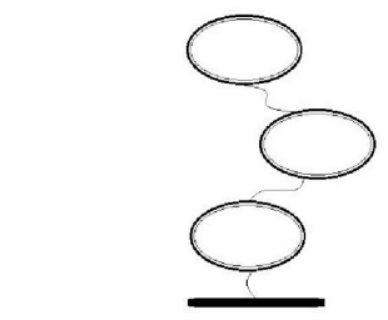

Biofilm is removed using a brush

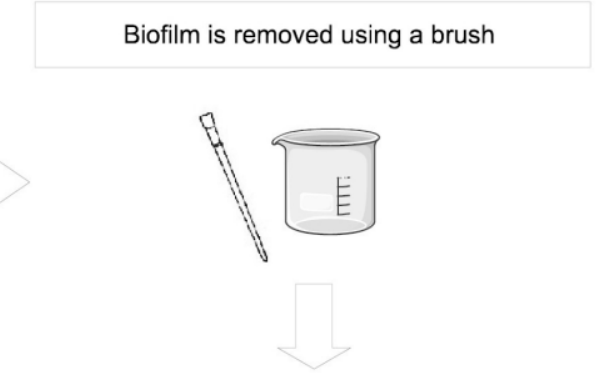

Inoculum from a pristine environment (lake)

This material is disposed into the aquarium, containing culture medium and glass slides
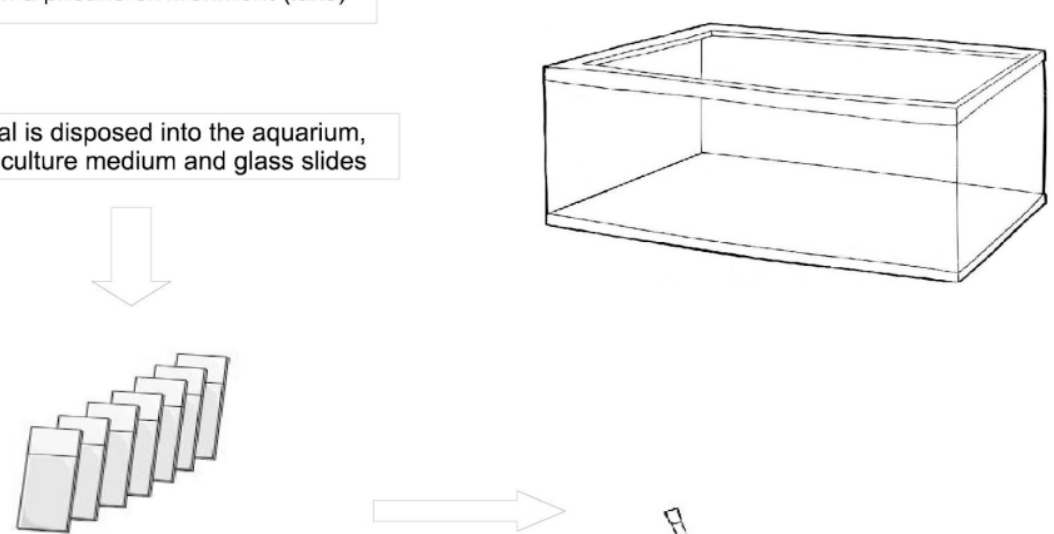

After three weeks, glass slides now covered in biofilm can be used in toxicity, ecological or biotechnological studies

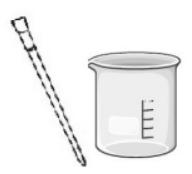

Chlorophyll content

Biomass

Identification

$\rightarrow$ Qualitative / Quantitative

$\rightarrow$ Ecological Indicators

Ash free dry mass - AFDM and Chlorophyll-a

These analyses were performed using the material from both the field (inoculum) and the culture tank. For field samples, the area of substrate colonized was measured and sampled. For the periphyton from the culture tank, the biofilm from one glass slide was used. In both cases, samples were taken in triplicate. 
In the culture tank, the potential spatial variation inside the tank was also measured, considering width and depth. To do this, the area of the tank was divided into 9 parts, as seen in Figure 2, and compared between them. For depth comparison, samples were grouped into three groups: $(1,2,3),(4,5,6),(7,8,9)$, and compared. For width comparison, they were grouped into $(1,4,7),(2,5,8),(3,6,9)$ and compared. Each group was sampled in triplicate.

Figure 2: Culture tank divided into different areas for AFDM and Chl-a analyses

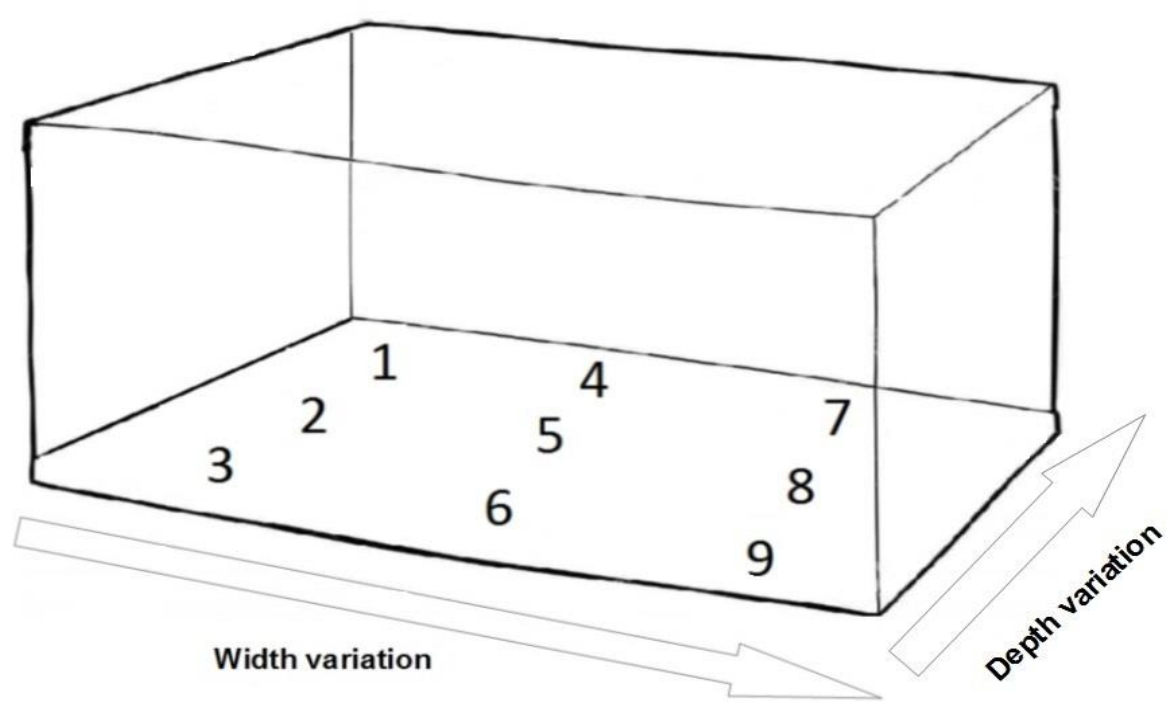

For AFDM, the samples were dried at $65^{\circ} \mathrm{C}$ in a oven to constant weight. Afterwards, the samples were combusted at $450^{\circ} \mathrm{C}$ for 60 minutes in a muffle furnace to obtain the ashes (ROBERTS et al., 2014). For chl-a concentration, the samples were filtered using glass fiber filters (Merck), and then macerated into 90\% acetone. The absorbance of the extract was measured in spectrophotometer (Micronal-B527), according to Torres et al. (2014).

\section{Ecological Analyses}

Taxonomic identification was performed for the autotrophic portion of the biofilm from culture tank and inoculum for comparison. Samples were taken from different parts of the tank to characterize the community from culture. For the inoculum, samples were taken from different parts of the lake. Samples were identified to species level, using the guides 
from Bicudo and Menezes (2006), Franceschini (2013), Ludwig and Tremarin (2013), and Lamparelli et al. (2014). Quantitative analysis was also performed using an Uthermol chamber, according to the protocol from Bicudo (1990), and then indexes of diversity, density and descriptive species were calculated at $2 \%$ of total density (Felisberto and Rodrigues, 2012).

\section{Data Analysis}

The artwork seen in this work was created using OriginPro 8.5 (OriginLab). The same program was also used to analyze significant alterations between the culture conditions for: AFDM, Chl-a, Species richness, Descriptive species, Diversity and density. It was used oneway ANOVA followed by Tukey's test $-\mathrm{p}<0.05$ (POTVIN, 2001). All tests were performed in triplicate $(n=3)$, The assumptions of normality and homoskedasticity were tested using Bartlett's test and Kolgomorov Smirnov's test, respectively.

\section{Results}

\section{Ash free dry mass - AFDM and Chlorophyll-a}

When measuring biomass production through ash free dry mass (AFDM), a significant difference between the communities from the lake (inoculum) and the culture tank was observed. When in natural conditions, biomass production was higher than that observed in culture tank $(\mathrm{p}<0.05)$ as seen in Figure 3a. When spatial variation between different parts of the tank was observed, there was no significant variation at all (Figure 3b).

When it comes to Chlorophyll-a concentration (Chl-a), significant differences were also observed in the field compared to culture $(\mathrm{p}<0.05)$, but not between areas from culture tank (Figure 3b). 
Figure 3: (a) AFDM and Chl-a variation between field and culture tank; (b) Spatial variation of AFDM and Chl-a inside the tank
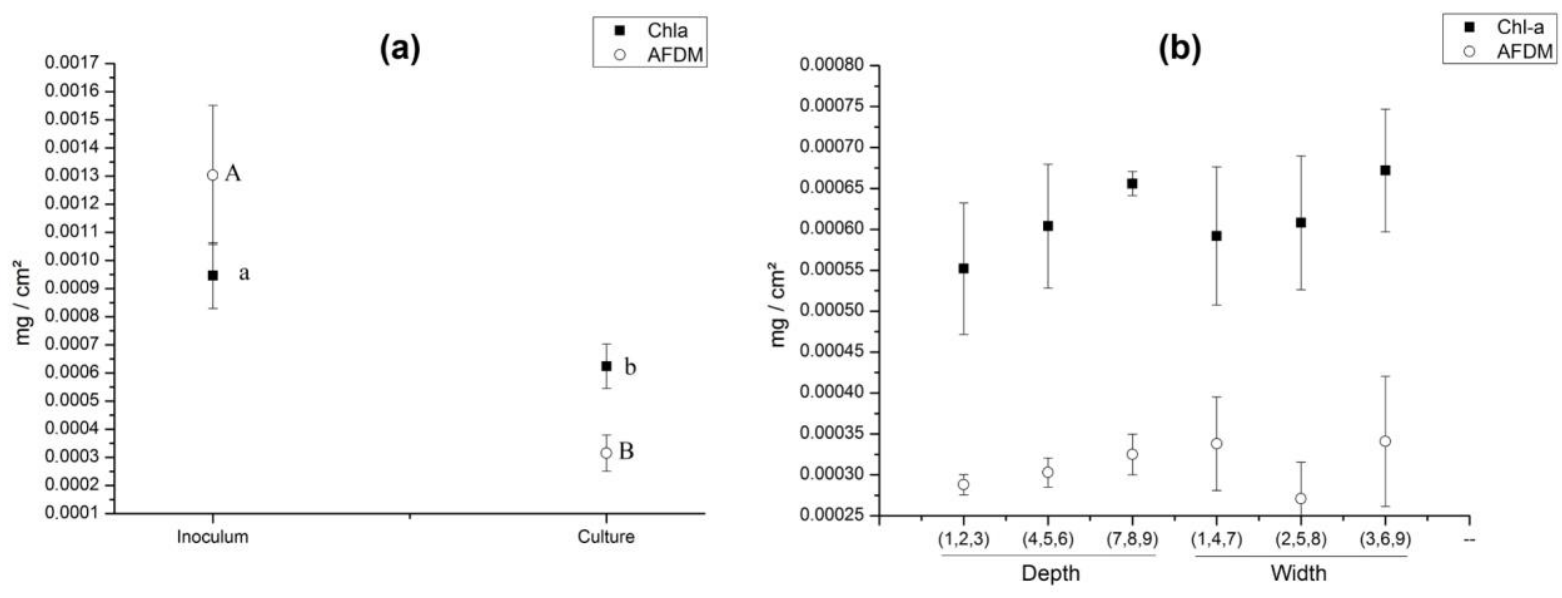

\section{Ecological Analyses}

Qualitative and quantitative identifications of the samples were performed comparing the inoculum and the culture tank populations. The first parameter observed, species richness, was not significantly different (Figure $4 \mathrm{a}$ ). About $80 \%$ of the species found in the inoculum community were also observed in the culture tank, resulting in a high similarity in composition. However, 11 species were identified from the inoculum samples only: Anabena sp., Ankistrodesmus fusiformis Corda, Closterium leibleinii Kützing ex Ralfs, Desmodesmus aculeolatus (Reinsch) P.M.Tsarenko, Geminella sp., Kirchneriella sp., Monoraphidium sp., Spirogera sp., Synetochoccus sp., Uronema sp. and Volvulina sp.. Another 11 species were identified only in culture samples: Calothrix braunii Bornet \& Flahault, Encynopsis sp., Euastrum sp., Gyrosigma sp., Nitzschia sp., Pseudanabena catenata Lauterborn, Phormidium foreaui (Frémy) Umezaki \& Watanabe, Raphidonema sp., Scenedesmus pectinatus Meyen, Tetradinium sp. and Tetrastum sp.

When considering descriptive species (Figure 4b) and diversity (Figure 4c), those parameters differed significantly from inoculum and the culture. The species Achantidium sp., Anabena sp., Aphanocapsa sp., Bulbochaete sp., Gonatozygon tenuissimum Playfair, Microcystis aeruginosa (Kützing) Kützing, Scenedesmus ecornis (Ehrenberg) Chodat and Ulnaria sp. were only described in inoculun samples. At the same time, Leibleinia epiphitica 
(Hieronymus) Compère, Pseudanabena minima (G.S.An) Anagnostidis, Phormidium foreaui, and Planktothrix agardii (Gomont) Anagnostidis \& Komárek were only described in culture. 
Figure 4 (a) Species richness- N, in inoculum and culture periphyton communities; (b) Descriptive species, in inoculum and culture periphyton communities and (c) Diversity - H', in inoculum and culture periphyton communities.
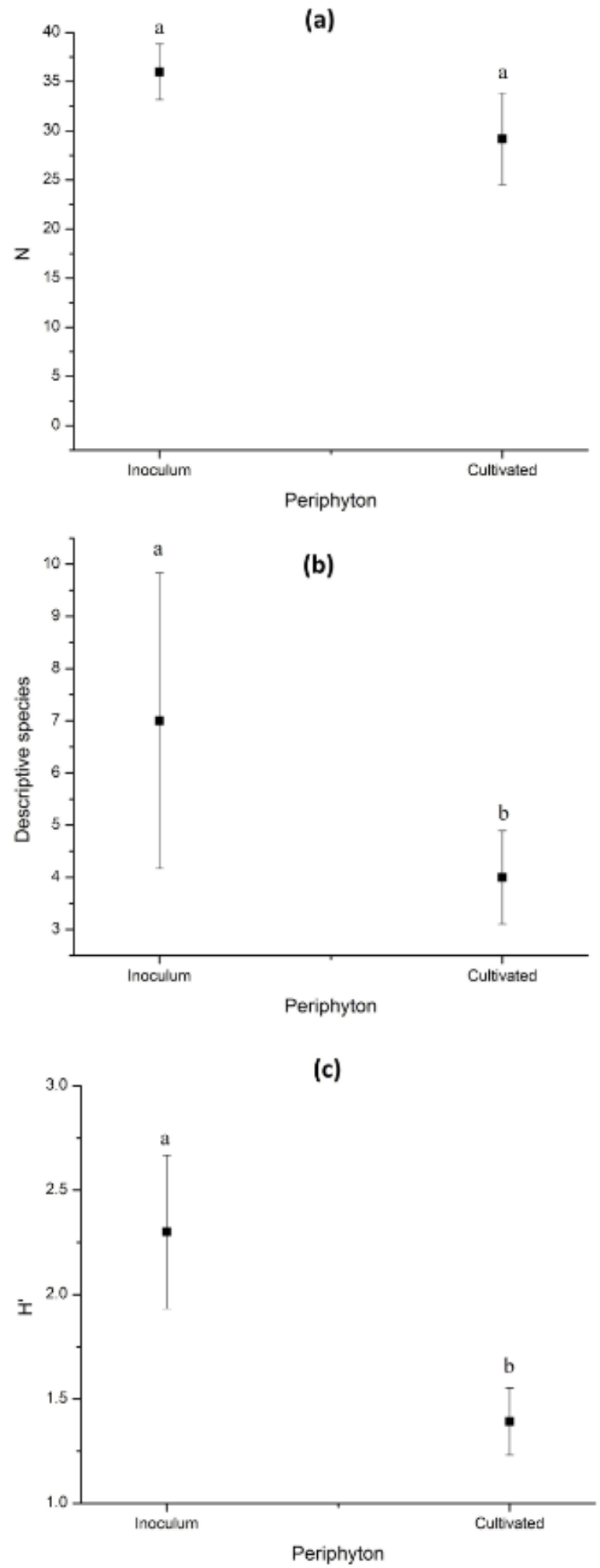
Total and partial density (considering the main algal groups) also differed significantly, with a higher density found in inoculum samples as observed in Figure 5. When observing the dominant groups and abundant species, Chlorophyceae was dominant for the inoculum and Scenedesmus quadricauda (Turpin) Brébisson and Planctolyngbya limnetica (Lemmermann) Komárková-Legnerová \& Cronberg were the most abundant. For the culture, Cyanophyceae was the dominant group, with $P$. limnética as the dominant species (with a density higher than $50 \%$ of the total).

Figure 5: Algal density of the samples, considering the different algal groups in inoculum and culture.

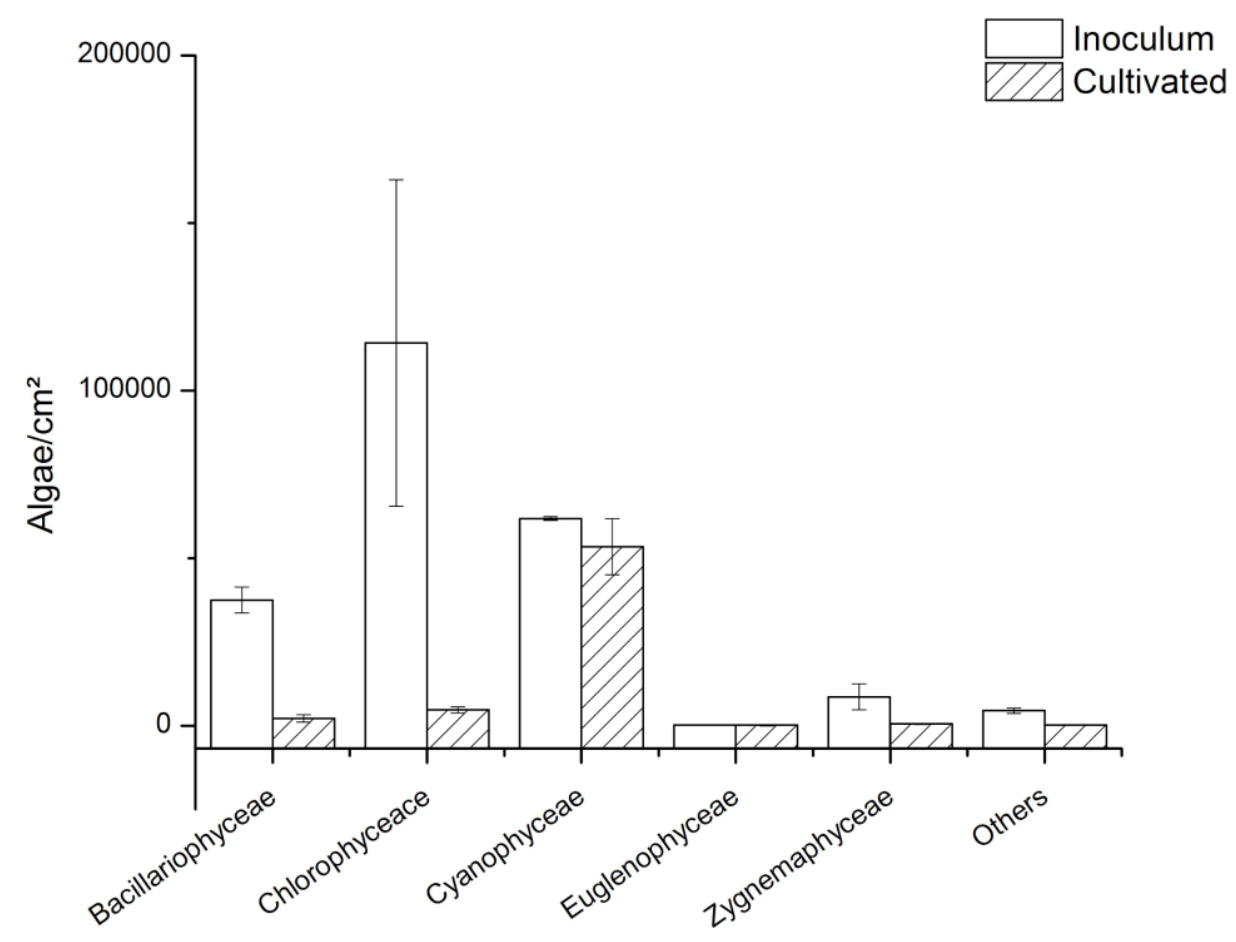

\section{Discussion}

When observing the potential spatial variation inside the culture tank, there were no differences. This means that the experimental design of the tank, considering water circulation and light exposure was homogeneous, resulting in a homogeneous biofilm layer on all the glass slides. Such factor is essential for ensuring replicability in experiments using the 
culture tanks method. Each glass slide can be evaluated as a independent community, colonized under the exact same conditions. This way, one single bath of periphyton culture can ensure the experimental replication in a ecotoxicological test, reducing operational costs and saving time.

Biomass production and chlorophyll-a concentration in the culture were significantly lower than the inoculum, showing that the community was not totally adapted to culture controlled conditions and resulting in species loss leading to structural differences. This hypothesis is corroborated by the ecological data obtained. The four ecological indexes measured: species richness - N, Shannon's diversity - H', total density and descriptive species, were higher in natural conditions (inoculum) than in the laboratory culture. While in field conditions Chlorophyceae was the dominant group, in culture conditions Cyanophyceae was dominant.

This can be explained by the specificity of different algal groups related to nutritional and environmental needs. Since the culture media used is focused on algal maintenance (ASSOCIAÇÃO BRASILEIRA DE NORMAS TÉCNICAS, 2018), other groups are nutritionally affected, as the composition of media for each group (bacteria, algae and fungi) is different (CORRY et al., 2012). Consequently, such circumstances lead to a different process of succession, and a different climax community.

In addition, some algal groups are less susceptible to laboratorial culture, even in a mixed culture as the culture tanks. In microbiology, the concept of "unculturable organisms" is used to describe species that can not be isolated using culture media (HANDSELMAN, 2004). As a result, those species are replaced by others that are more adapted to the controlled conditions found in laboratory, leading to lower primary production, as found in AFDM results.

Furthermore, the culture tank must present constant temperature, and controlled light exposure and oxygenation. This contrasts with the conditions found in the natural environment, where these variables vary seasonally or even daily. Natural environments are also susceptible to nutritional variations and dry seasons, creating several ecological niches due to the higher environmental heterogeneity, which leads to higher diversity and species richness (ALGARTE et al., 2017). However, to ensure the replicability of laboratory tests and avoid misunderstandings in results, controlled culture conditions are essential (FERRAGUT et al., 2013). The same aspect is observed in different methods, as a recurrent consequence when periphyton is cultivated in the laboratory. Guash and Serra (2009) reported this for 
artificial channels method, presenting satisfactory results in toxicity tests. When studying bioreactors, Ugwu et al. (2008) also pointed out the challenges in cultivating certain algal groups due to the limitations of the method. This situation creates a dilemma where no culture method embraces the needs of all species in a natural community, leading to loss of diversity and ecological relationships (TANG et al., 2017). An alternative to minimize the difference between inoculum and laboratory conditions, would be to increase the cultivation period. In field conditions the period of 21 days suggested by Torgan et al. (2013) was enough to the development of periphyton. However considering the results obtained, in laboratory conditions, this step could be extended in order to obtain a community closer to the found in the inoculum.

Even with a less diverse community, the culture tank presented high similarity in species with the inoculum ( $80 \%$ ), showing that the method was able to create conditions for most species to survive, and maintain ecological relations between themselves. The difference is in the distribution of the species in the biofilm: Cyanobacteria and Euglenophyceae were not affected by culture conditions, maintaining the same density as the inoculum, however Chlorophyceae, Bacillariophyceae and Zygnematophyceae were negatively affected.

Considering this, tests performed using the biofilm cultivated in the laboratory should emphasize the effects of experimental manipulation on the species affected in culture conditions, instead of directly comparing the data obtained in the laboratory and that observed in natural environments. Also, the loss of species caused by culture condition adaptations can also lead to a loss of ecological relations (Tang et al). So, before performing ecotoxicological tests using this methodology, it is necessary to evaluate if these structural changes could affect negatively the result aimed, or even invalidate the research.

Concerning costs and production capacity, the method of culture tank used in this study costs approximately US\$200.00; including all the equipment, the tank and artificial subtracts for colonization. Total production of periphyton was of $111.3 \mathrm{~g}$ of dry mass, divided by 112 glass slides, homogeneously covered after 21 days of incubation. The main advantage of using glass slides as colonization substrate is that they optimize the use of periphyton, reducing manipulation of the community. Therefore, only the necessary number of slides are collected, which do not affect the remaining ones. Each slide is an independent community, providing versatility and replicability when designing toxicity experiments.

In comparison, the artificial channels method, using the same amount of colonizing substrate, would cost approximately US\$ 450.00. This estimate does not consider the costs of 
support structures and water transportation from a river/well to the laboratory, which vary depending on the location. These values were calculated using the experimental designs described by Guash and Serra (2009) and Navarro et al. (2000), with current quotation.

Finally, the quantity and quality of the biofilm produced was appropriate for its utilization in ecotoxicity tests, as seen in Sousa et al. (2019), or biotechnological essays, on a small scale. Thus, the method proposed here can be used to reduce the total costs of experiments conducted in the laboratory, or as a preliminary step before field studies.

\section{Conclusions}

The method effectively produced an homogeneous periphytic biofilm in the laboratory, based on an inoculum from a natural environment. Since several conditions are strictly controlled in the laboratory, periphyton application in ecotoxicity tests is possible, providing replicability.

However, this method presented differences in community structure between the inoculum and the culture, as some species were unable to adapt to laboratory conditions, leading to lower species density and diversity. So, the application of this methodology in ecotoxicological tests should consider this limitation, in order to avoid erroneous conclusions.

Contrarily, this method presents advantages such as a reduced cost and higher capacity of manipulation. Therefore, the culture tanks are an alternative to the field approach in some studies. The differences between natural and cultivated communities must be considered, depending on the focus of the study.

\section{References}

ASSOCIAÇÃO BRASILEIRA DE NORMAS TÉCNICAS. Ecotoxicologia aquática toxicidade crônica - método de ensaio com algas (Chlorophyceae) - Normativa NBR 12648:2018. Brasília, 2019. Disponível em: http://www.abntcatalogo.com.br/norma.aspx?ID=391089. Acessado em 1.3.2019.

ALGARTE, V.M.; SIQUEIRA, T.; LANDEIRO, V.L.; RODRIGUES, L.; BONECKER, C.C.; RODRIGUES, L.C.; SANTANA, N.F.; THOMAZ, S.M.; BINI, L.M. Main predictors of periphyton species richness depend on adherence strategy and cell size. Plos One, San Francisco, v. 12, n. 1, , p. 1-14, 2017. https://doi.org/10.1371/journal.pone.0181720 
BERE, T.; CHIA, M.A.; TUNDISI, J.G. Effects of Cr III and Pb on the bioaccumulation and toxicity of $\mathrm{Cd}$ in tropical periphyton communities: Implications of pulsed metal exposures. $\begin{array}{llllllll}\text { Environmental Pollution, } & \text { v. } 163, \quad \text { n. } & 1, & \text { p. } & 184-191, & \end{array}$ https://doi.org/10.1016/j.envpol.2011.12.028

BICUDO, C.E.M. Metodologia para o estudo qualitativo do perifíton. Acta Limnologica Brasilica, v. 3, n. 1, p. 447-491, 1990.

BICUDO, C.E.M.; MENEZES, M. Gêneros de algas continentais no Brasil: guia para identificação e descrições. 1. ed. São Carlos: Rima, 2006. 522 p.

CAVALCANTE, D.H.; LIMA, F.R.S.; REBOUÇAS, V.T.; SÁ, M.V.C. Underwater structures for periphyton in bioflocs tanks for Nile tilapia submitted to feed restriction. Acta Scientarium: Animal Sciences, Maringá, v. 39, n. 2, p. 117-122, 2017. http://dx.doi.org/10.4025/actascianimsci.v39i2.33122

CORCOLL, N.; CASELLAS, M.; HUERTA, B.; GUASCH, H.; ACUÑA, V.; RODRÍGUEZMOZAZ, S.; SERRA-COMPTE, A.; BARCELÓ, D.; SABATER, S. Effects of flow intermittency and pharmaceutical exposure on the structure and metabolism of stream biofilms. Science of the Total Environment, v. 503-504, p. 159-170, 2015. https://doi.org/10.1016/j.scitotenv.2014.06.093

CORRY, J.E.L.; CURTIS, G.D.W.; BAIRD, R.M. Handbook of culture media for food and water microbiology. $3^{\mathrm{a}}$ ed. Cambridge: RSC Publishing, 2012. 1006 p.

FELISBERTO, S.A.; MURAKAMI, E.A. Papel do perifíton na ciclagem de nutrientes e na teia trófica. In: SCHWARZBOLD, A.; BURLIGA, A.L.; TORGAN, L.C. (Eds). Ecologia do perifíton, 1st ed., São Carlos: Rima, 2013. p. 23-44.

FELISBERTO, S.A.; RODRIGUES, L. Dinâmica sucessional de comunidade de algas perifíticas em um ecossistema lótico subtropical. Rodriguésia, v. 63, n.1, p. 463-473, 2012.

FERRAGUT, C.; BICUDO, D.C.; VERCELLINO, I.S. Amostragem e medidas de estrutura na comunidade perifítica. In: SCHWARZBOLD, A.; BURLIGA, A.L.; TORGAN, L.C. (Eds). Ecologia do perifíton, 1st ed., São Carlos: Rima, 2013. p. 157-177.

FRANCESCHINI, I.M. Chave de identificação dos gêneros de algas (exceto Bacillariophyceae) comumente encontrados no perifíton e metafíton de ambientes aquáticos continentais. In: SCHWARZBOLD, A.; BURLIGA, A.L.; TORGAN, L.C. (Eds). Ecologia do perifíton, $1^{a}$ ed., São Carlos: Rima, 2013. p. 245-266.

GAISER, E.E.; ANDERSON, E.P.; CASTAÑEDA-MOYA, E.; COLLADO-VIDES, L.; FOURQUREAN, J.W.; HEITHAUS, M.R.; JAFFE, R.; LAGOMASINO, D.; OEHM, N.J.; PRICE, R.M.; RIVERA-MONROY, V.H.; CHOWDARY, R.R.; TROXLER, T.G. New perspectives on an iconic landscape from comparative international long-term ecological research. Ecosphere, v. 6, n. 1, p. 1-18, 2015. https://doi.org/10.1890/ES14-00388.1

GROSS, M.; JARBOE, D.; WEN, Z. Biofilm-based algal cultivation systems. Applied

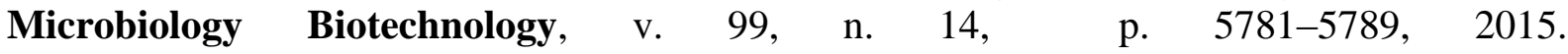
https://doi.org/10.1007/s00253-015-6736-5 
GUASH, H.; SERRA, A. Uso de ríos artificiales en ecología fluvial. In: ELOGESI, A.; SABATER, S. (Eds) Conceptos y técnicas en ecología fluvial, $1^{\mathrm{a}}$ ed, Bilbao: Fundación BBVA, 2009. p. 387-395.

HOMMEN, U.; KNOPF, B.; RÜDEL, H.; SCHÄFERS, C.; GARMAN, E.R.; SCHAMPHELAERE, K.; SCHLEKAT, C. A microcosm study to support aquatic risk assessment of nickel: community-level effects and comparison with bioavailabilitynormalized species sensitivity distributions. Environmental Toxicology and Chemistry, Toronto, v. 35, n. 5, p. 1172 -1182, 2016. https://doi.org/10.1002/etc.3255

HANDELSMAN, J. Metagenomics: Application of Genomics to Uncultured Microorganisms. Microbiology Molecular and Biology Research, Washington, v. 68, n. 4, p. 669-685, 2004. https://doi.org/10.1128/MMBR.68.4.669-685.2004

KESAANO, M.; SIMS, R.C. Algal biofilm based technology for wastewater treatment. Algal Research, v. 5, n. 1, p. 231-240, 2014. https://doi.org/10.1016/j.algal.2014.02.003

KAZANJIAN, G.; VELTHUIS, M.; ABEN, R.; STEPHAN, S.; PEETERS, E.T.H.M.; FRENKEN, T.; TOUWEN, J.; FEI, X.; KOSTEN, S.; VAN DE WAAL, D.B.; DOMIS, L.N.S.; DONK, E.; HILT, E. Impacts of warming on top-down and bottom-up controls of periphyton production. Scientific Reports, v. 8, n. 1, p. 9901. https://doi.org/10.1038/s41598018-26348-x

LAMPARELLI, M.C.; TUCCI, A.; SANT'ANNA, C.; PIRES, D.A.; LERCHE, L.H.M.; CARVALHO, M.C.; ROSAL, C. Cianobactérias da região do Alto Tietê. São Paulo: CETESB, 2014. 96 p.

LIESS, A.; HILLEBRAND, H. Invited review: Direct and indirect effects in herbivore periphyton interactions. Archiv fur Hydrobiolgie, v. 159, n. 4, p. 433-453, 2004. https://doi.org/10.1127/0003-9136/2004/0159-0433

LUDWIG, T.A.V.; TREMARIN, P.I. Chave de identificação dos gêneros de diatomáceas (Diatomae-Ochrophyta) comumente encontrados no perifíton e metafíton de ambientes aquáticos continentais. In: SCHWARZBOLD, A.; BURLIGA, A.L.; TORGAN, L.C. (Eds). Ecologia do Perifíton, $1^{a}$ ed., São Carlos: Rima, 2013. p. 267-330.

MAHDY, A.; SCHAFENBERGER, U.; ADRIAN, R.; HILT, S. Experimental comparison of periphyton removal by chironomid larvae and Daphnia magna. Inland Waters, Londres, v. 5, n. 1, p. 81-88, 2014. https://doi.org/10.5268/IW-5.1.755

NAVARRO, E.; GUASCH, H.; MUNOZ, I.; REAL, M.; SABATER, S. Aplicación de um sistema de canales artificiales en el estudio ecotoxicológico de comunidades microbentonicas. Limnnetica, v. 18, n.1, p. 1 - 14, 2000.

NAVARRO, E.; ROBINSON, C.T.; BEHRA, R. Increased tolerance to ultraviolet radiation (UVR) and cotolerance to cadmium in UVR-acclimatized freshwater periphyton. Limnology and Oceanography, v. 53, n. 3, p. 1149-1158, $2008 . \quad$. https://doi.org/10.4319/10.2008.53.3.1149 
NEWMANN, M.C. Fundamentals of Ecotoxicology: The Science of Pollution. Boca Ratón: CRC Press, 2015. 680 p.

PENNUTO, C.M.; CUDNEY, K.A.; JANIK, C.E. Fish invasion alters ecosystem function in a small heterotrophic stream. Biological Invasions, v. 20, n. 4, p. 1033-1047,2018. https://doi.org/10.1007/s10530-017-1609-8

POTVIN, C. ANOVA: experimental layout and analysis. In: SCHNEIDER, S.M.; GUREVITCH, J. (Eds) Design and analysis of ecological experiments. $2^{\mathrm{a}}$ ed, New York: Oxford university press, 2001. p. 63-77.

ROBERTS, M.J.; LONG, S.P.; TIESZEN, L.L.; BEADLE, C.L. Measurement of plant biomass and net primary production. In: COOMBS, J.; HALL, D.O.; LONG, S.P.; SCURLOCK, J.M.O. (Eds). Techniques in bioproductivity and photosynthesis. $2^{\mathrm{a}}$ ed, Oxford: Pergamon Press, 2014. p. 1-19.

SHABBIR, S.; FAHEEM, M.; ALI, N.; KERR, P.G.; YONGHONG, W. Periphyton biofilms: A novel and natural biological system for the effective removal of sulphonated azo dye methyl orange by synergistic mechanism. Chemosphere, v. 167, n.1, p. 236-246, 2017. https://doi.org/10.1016/j.chemosphere.2016.10.002

SCHNECK, F. Tendências e lacunas dos estudos sobre perifíton de ambientes aquáticos continentais no Brasil: Análise cienciométrica. In: SCHWARZBOLD, A.; BURLIGA, A.L.; TORGAN, L.C. (Eds.) Ecologia do perifíton. São Carlos: Rima, 2013. p. 7-22.

SCHMITT-JANSEN, M.; BLEY, L.M.; KRUMBIEGEL, M.L.; ROTTER, A. Induced community tolerance of periphyton towards combined salt and toxic stress. Freshwater Biology, v. 61, n. 1, p. 2152-2161, 2016. https://doi.org/10.1111/fwb.12799

SCHWARZBOLD, A. Métodos de estudo da produção primária do perifíton. In: SCHWARZBOLD, A.; BURLIGA, A.L.; TORGAN, L.C. (Eds.) Ecologia do perifíton. São Carlos: Rima, 2013. p. 179-214.

SOUSA, M.L.; CHOW, F.; POMPÊO, M.L.M. Community-level changes in periphytic biofilm caused by copper contamination. Journal of Applied Phycology, 2019. https://doi.org/10.1007/s10811-019-1734-0

TANG, J.; NINGYUAN, Z.; YAN, Z.; JUNZHUO, L.; CHENXI, W.; KERR, P.; YONGHONG, W.; LAM, P.K.S. Responses of periphyton to Fe2O3 nanoparticles: A physiological and ecological basis for defending nanotoxicity. Environmental Science and $\begin{array}{llllll}\text { Technology, } & \text { v. 51, n. 18, p. } 10797-10805,\end{array}$ https://doi.org/10.1021/acs.est.7b02012

TLILI, A.; BERARD, A.; BLANK, H.; BOUCHEZ, A.; CASSIO, F.; ERIKSSON, K.M.; MORIN, S.; MONTUELlE, B.; NAVARRO, E.; PASCOAL, C.; PESCE, E.; SCHMITTJANSEN, M.; BEHRA, R. Pollution-induced community tolerance (PICT): towards an ecologically relevant risk assessment of chemicals in aquatic systems. Freshwater Biology, v. 61, n. 1, p. 2141-2151, 2016. https://doi.org/10.1111/fwb.12558 
TORGAN, L.C.; BERTOLLI, L.M.; TALGATTI, D.M.; SALMONI, S. Colonização e sucessão do perifíton. In: SCHWARZBOLD, A.; BURLIGA, A.L.; TORGAN, L.C. (Eds.) Ecologia do perifíton. São Carlos: Rima, 2013. p. 45-58

TORRES, P.B.; CHOW, F.; FURLAN, C.M.; MANDELLI, F.; MERCADANTE, A.; SANTOS, D.Y.A.C. Standardization of a protocol to extract and analyze chlorophyll a and carotenoids in Gracilaria tenuistipitata Var. Liui. Zhang and Xia (Rhodophyta). Brazilian Journal of Oceanography, São Paulo, v. 62, n. 1, p. 57-63, 2014. https://doi.org/10.1590/s1679-87592014068106201

UGWU, C.U.; AOYAGI, H.; UCHIYAMA, H. Photobioreactors for mass cultivation of algae. Bioresource Technology, v. 99, n. 10, p. 4021-4028, 2008. https://doi.org/10.1016/j.biortech.2007.01.046

VAL, J.; MUÑIZ, S.; GOMÀ, J.; NAVARRO, E. Influence of global change-related impacts on the mercury toxicity of freshwater algal communities. Science of the Total Environment, v. 540, n. 1, p. 53-62, 2016. https://doi.org/10.1016/j.scitotenv.2015.05.042

WALKER, C. Ecotoxicology: Effects of Pollutants on the Natural Environment. $1^{\text {a }}$ ed, Boca Ratón: CRC Press, 2014. 233 p.

WINGARD, G.L.; LORENZ, J.J. Integrated conceptual ecological model and habitat indices for the southwest Florida coastal wetlands. Ecological Indicators, v. 44, n. 1, p. 92-107, 2014. https://doi.org/10.1016/j.ecolind.2014.01.007

YONGHONG, W. Periphyton: functions and applications in environmental remediation. 1 ed., Amsterdam: Elsevier, 2016. 434 p. 


\section{Supplementary Material}

Figure I: Place where inoculum was obtained

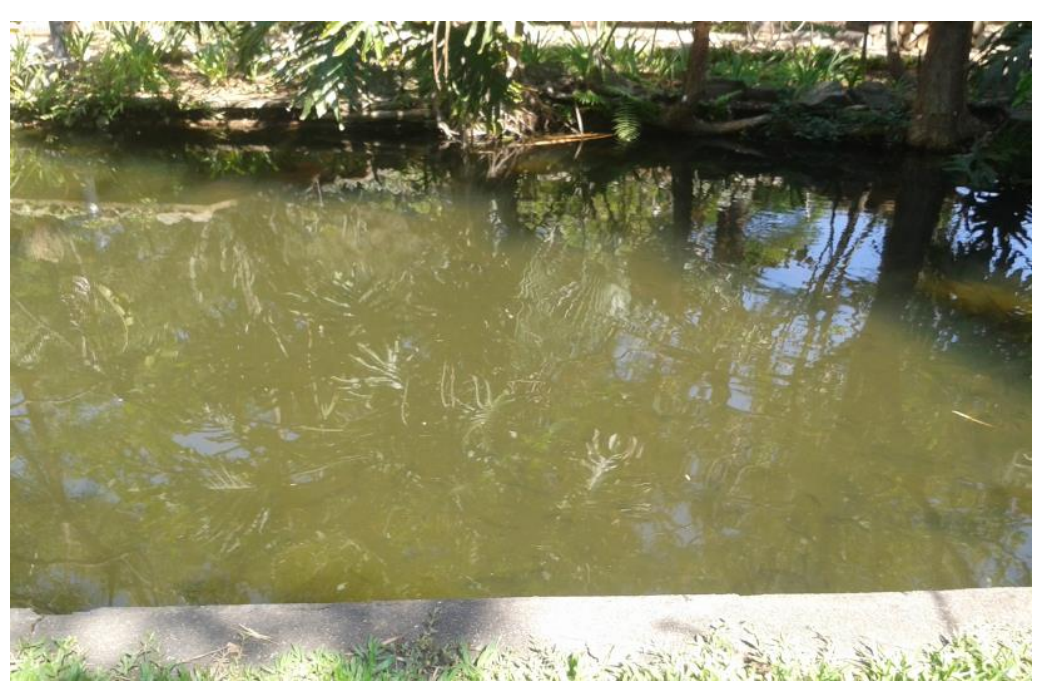

Figure II: Plastic slides for inoculum colonization

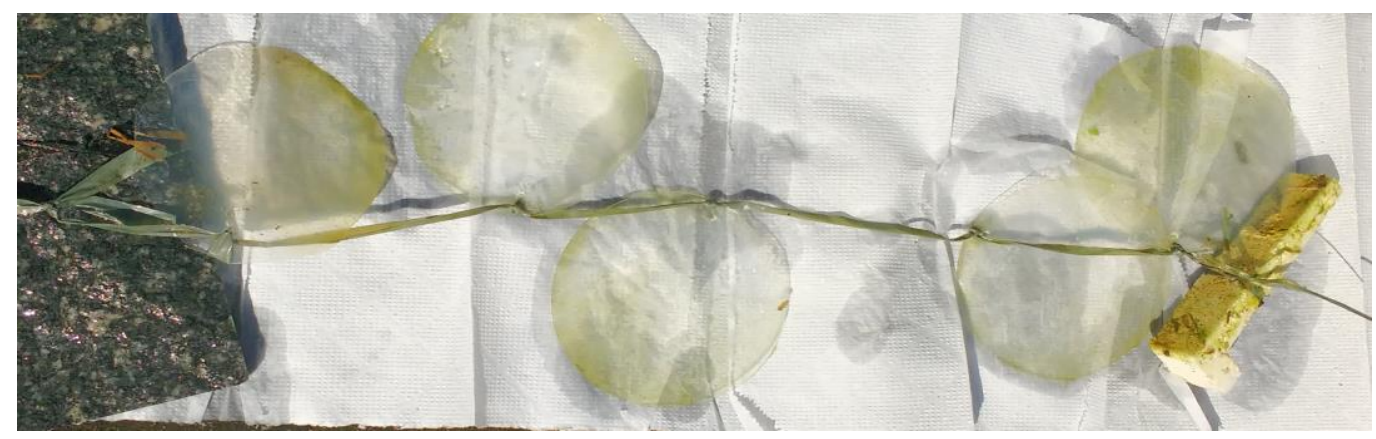

Figure III: Aquarium during inoculation, glass slides supports and air curtain diffusers 


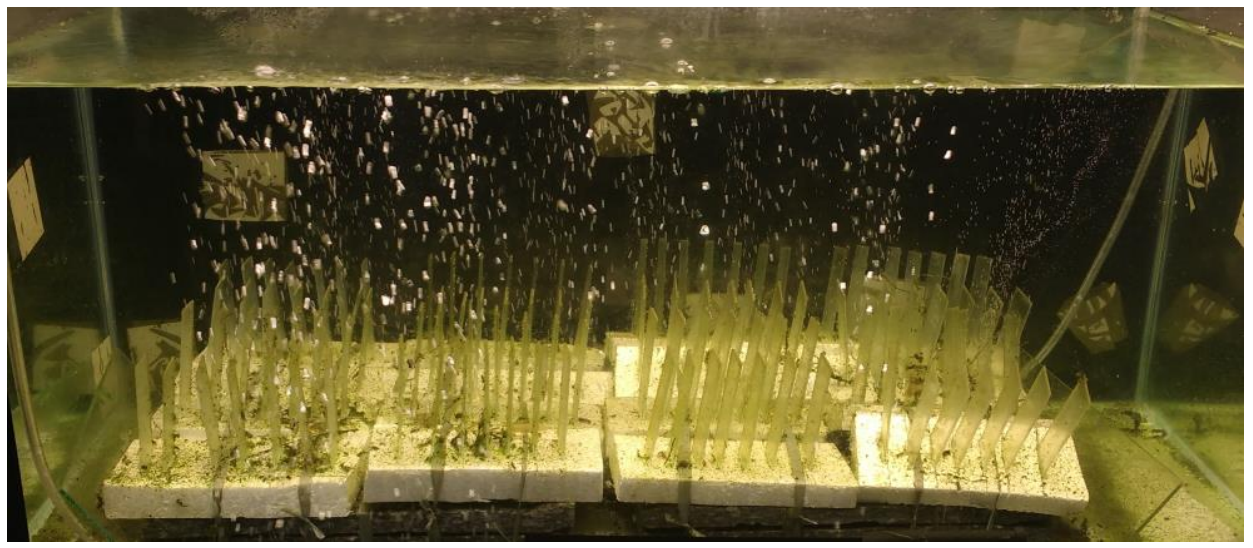

Figure VI: Glass slide after colonization

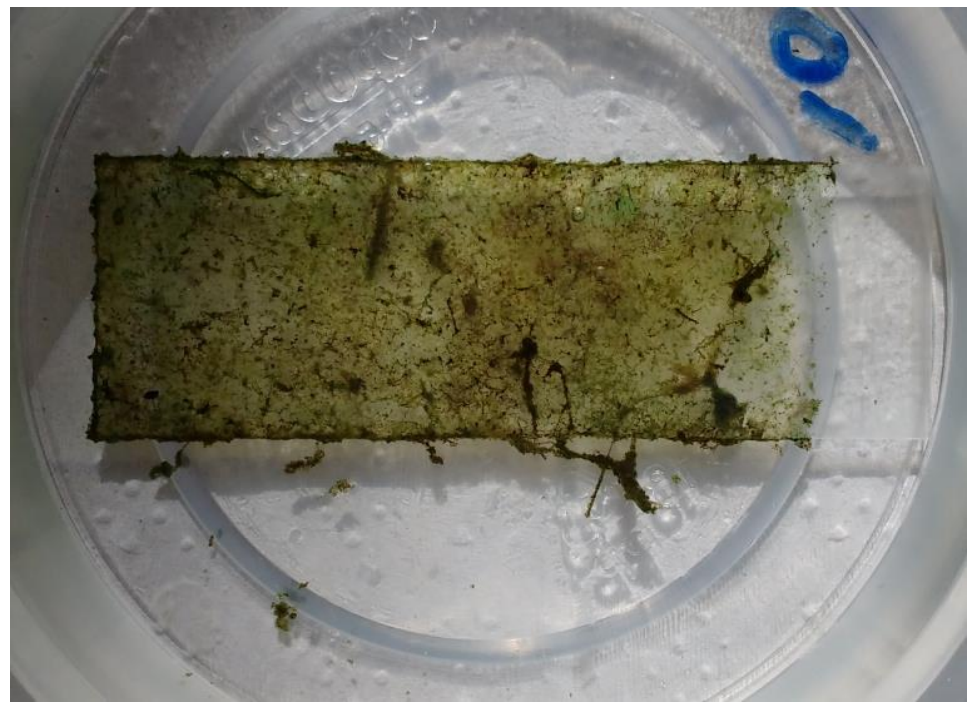




\title{
Capítulo 3
}

\section{COMMUNITY-LEVEL CHANGES IN PERIPHYTIC BIOFILM CAUSED BY COPPER CONTAMINATION}

\author{
Mariana L. Sousa ${ }^{1}{ }^{*}$; Fungyi Chow ${ }^{2}$; Marcelo L.M. Pompêo ${ }^{1}$ \\ ${ }^{1}$ Laboratory of Limnology, Department of Ecology, Institute of Bioscience, University of São \\ Paulo. Rua do Matão 321, CEP 05508-090. São Paulo, SP, Brazil. \\ ${ }^{2}$ Laboratory of Marine Algae "Édison José de Paula", Department of Botany, Institute of \\ Bioscience, University of São Paulo. Rua do Matão 321, CEP 05508-090, São Paulo, SP, \\ Brazil.
}

*Trabalho publicado no periódico Journal of Applied Phycology. 


\section{Resumo}

O perifíton é um elemento reconhecidamente importante nas cadeias alimentares aquáticas, devido seu papel como produtor primário. Recentemente, essa comunidade tem sido usada como bioindicador para avaliação da contaminação em reservatórios, já que o biofilme é uma ferramenta essencial para se compreender os efeitos "bottom-up" neste ambiente. O Cobre $(\mathrm{Cu})$, é um contaminante amplamente utilizado como algicida, que se acumula no sedimento e é ressuspendido para a coluna d'água, causando danos a diversos organismos, a partir do perifíton. Neste trabalho, o perifíton cultivado em laboratório foi exposto ao $\mathrm{Cu}$ em concentrações variando entre 0,013 to $0,15 \mathrm{mg} \mathrm{Cu} \mathrm{L}^{-1}$ por 15 dias sob condições controladas de cultivo (luz, temperatura e oxigenação). Diferentes parâmetros físico-químicos e ecológicos foram avaliados com o objetivo de esclarecer os efeitos do $\mathrm{Cu}$ na comunidade perifítica. Foram estudadas: massa seca livre de cinzas, clorofila-a, e potencial fotossintético. Os resultados mostraram um diferente comportamento ecológico da comunidade, com aumento da dominância de cianobactérias e de espécies com presença de mucilagem á medida que a concentração de $\mathrm{Cu}$ aumentou. Além disso, algumas espécies de diatomáceas desapareceram após a contaminação por $\mathrm{Cu}$. Essas alterações na composição da comunidade afetam diretamente a cadeia alimentar, devido a impalatabilidade das espécies resistentes ao cobre ou bioacumulação do mesmo nas células, o que causaria intoxicação dos consumidores do perifíton.

Palavras-chave: Bioindicador, Metal, Microalga, Microcosmo, Toxicidade, Qualidade da àgua. 


\begin{abstract}
Periphyton has been recognized as an important element in aquatic food chains, due to its role in primary production. More recently, it has been used as bioindicator of contamination in reservoirs, since biofilm analysis can support in understanding the impacts of bottom-up contaminants to the reservoirs. Copper $(\mathrm{Cu})$ is one of these pollutants which has been used as an algicide, it accumulates in the sediment and can be released to the water column, causing harm to various aquatic organisms, including the periphytic biofilm. In this work, periphyton cultivated in the laboratory was exposed to copper, using concentrations from 0.013 to $0.15 \mathrm{mg} \mathrm{Cu} \mathrm{L-1}$ over 15 days, under controlled conditions (temperature, light and oxygenation). Different physical-chemical and ecological parameters were measured in order to describe the effects of $\mathrm{Cu}$ on the community, which included alterations in ash-free dry mass and chlorophyll concentration, as well as an earlier photosynthetically light saturation point. The results reflected a different ecological behavior with modifications in the community composition and greater Cyanobacteria dominance like abundance of species with mucilage as the $\mathrm{Cu}$ concentration increased. Furthermore, some species of diatoms were not found when the water was contaminated with $\mathrm{Cu}$. This disturbance in the ecological composition of periphyton affects significantly the food chain, due to the unpalatability of tolerant species and/or the bioaccumulation of $\mathrm{Cu}$ which may be transferred to other organisms potentially causing toxicity to primary consumers.
\end{abstract}

Keywords: Bioindicator, Metal, Microalgae, Microcosm, Toxicity, Water quality. 


\section{Introduction}

Periphyton is a complex community of microbiota composed mainly by microalgae, bacteria, fungi, and zooplankton growing attached to any submerged substratum. Along with organic and inorganic detritus it forms a slimy coating surface in aquatic ecosystems. (WETZEL, 1983; YONGHONG, 2016). As a result, periphyton is a structured threedimensional community immersed in extracellular polymeric substances (EPS), that are responsible for retaining nutrients as well as contaminants (STEWART et al., 2013) and contributes to a large part of primary production (GAISER et al., 2015). The advantage of using periphyton for studying environmental contamination is that the entire community can represents different scales of pollution and it is possible to not only measure the impacts of contamination, but also to study the tolerance to a contaminant (YONGHONG, 2016).

A difficulty in most of the current ecotoxicological tests is that they are still based on the use of isolated species, individually, and therefore do not reflect natural conditions. Schaefer et al. (2012) pointed out that certain concentrations of contaminants are able to kill isolated algal species in laboratory, but not in field studies using the whole periphytic biofilm. The opposite was also observed by Hommen et al. (2016), where certain species were more sensitive in community context, than isolated conventional tests. These effects occur due to the loss of ecological interactions that would normally occur in the community, which are responsible for a completely different response to contamination (TANG et al., 2017).

Due to its substance-retaining characteristics, periphyton is specially used to evaluate bioaccumulating contaminants, such as metals (SERRA et al., 2009) which are accumulated in the periphytic biofilm and transferred to other trophic levels (SCHEIBENER et al., 2017). Leguay et al. (2016) showed that periphyton is a reliable indicator of the bioavailability of metals, through several ecological parameters during a period of three years. Lopez et al. (2017) also presented that different species, even the closely related ones, may vary significantly their responses to metal contamination, impacting directly other trophic levels.

Copper $(\mathrm{Cu})$ is one of the most common metal found in water ecosystems due to its use as herbicide, fungicide and algicide (Lambert et al. 2016). In the form of $\mathrm{CuSO} 2$, it has been extensively applied at high concentrations in tropical (POMPÊO et al., 2013) or temperate (GARCIA-VILLADA et al., 2004; SONG \& WANG, 2015) lakes and reservoirs to avoid algal blooms. However, a large part of the $\mathrm{Cu}$ becomes trapped within the sediment, presenting potential toxicity to the biota (BEGUELLI et al., 2015; SILVA, 2013) and causing 
a constant environmental problem. In algae, excessive $\mathrm{Cu}$ exposition causes damages to photosynthetic systems, acting directly in the thylakoid membrane and the electron transport chain (KUMAR et al., 2014).

According to Leal (2018), it is estimated that 4,530,050 tons of $\mathrm{Cu}$ have been applied to the Guarapiranga Reservoir (Brazil) in the last 43 years. This concentration has a significant impact on the quality of the sediment composition, considering that about $80 \%$ of the bottom area has $\mathrm{Cu}$ concentrations above the PEL (Probable Effect Level). Also in $44 \%$ of the bottom concentrations are more than ten times higher than the PEL. Nonetheless, algal blooms are still common (POMPÊO et al., 2013), once algae cells become resistant to the algicide under conditions of high inputs of organic matter, extreme $\mathrm{pH}$ values, and favorable climatic conditions (OLIVER \& RIBEIRO, 2014; LAMBERT et al., 2016).

This study explores the alterations caused by different $\mathrm{Cu}$ concentrations in periphytic biofilm, employing an ecotoxicological test with periphyton grown in the laboratory controlled conditions. Once the experiment was performed under concentrations easily found in Brazilian reservoirs, our hypothesis is that $\mathrm{Cu}$ can change the group of descriptive species, so as affecting the primary production, without impair completely the community. Quantitative analysis and taxonomic characterization of the algal community were performed, and evaluation was made on the effect of $\mathrm{Cu}$ addition on species diversity, dominance, and richness. Ash-free dry mass (AFDM), chlorophyll-a, and photosynthesis were measured and compared with the ecological parameter results for assessing the tolerance of the periphyton to $\mathrm{Cu}$ contamination. It is expected to explain the changes in distribution of different algal groups among the $\mathrm{Cu}$ concentration gradient, considering both biological and ecological alterations in biofilm composition.

\section{Methodology}

\section{Periphyton inoculation and acclimatization}

Plastic surfaces $(75 \mathrm{~mm}$ x $26 \mathrm{~mm}$ ) made of PolyEthylene Terephthalate (PET) were used as artificial substrate for periphyton inoculum growth. They were left in an artificial lake at the University of São Paulo (São Paulo, Brazil) for 21 days of colonization (TORGAN et al., 2013). The lake is free from metal contamination and it was monitored to assure its 
quality. Once developed periphyton, an inoculum was collected using a soft brush, and then transferred to a $50 \mathrm{~L}$ aquarium containing the glass slides vertically fixed $(2.6 \times 7.5 \mathrm{~cm})$ and culture medium LC Oligo (ASSOCIAÇÃO BRASILEIRA DE NORMAS TÉCNICAS, 2018). This oligotrophic medium contains low concentrations of metals, and is highly recommended for ecotoxicological tests with algae, avoiding any interference in the results that might be caused by trace metals present in the medium. The complete composition of LC Oligo is available in Table I of Supplementary Material.

For periphyton growth, the aquarium was kept under laboratorial controlled conditions. Illumination was provided using $16 \mathrm{~W}$ fluorescent lamps for periods of $12 \mathrm{~h}$ daily, aeration was provided using two $3 \mathrm{~W}$ air pumps (model s2000, Boyu) and air curtain bubble diffusers. The temperature was maintained at $24{ }^{\circ} \mathrm{C}$ using a $100 \mathrm{~W}$ heater and thermostat (model At-100, Atmam). The culture medium and water lost by evaporation were replaced on a weekly basis, and the $\mathrm{pH}$ was adjusted to $\mathrm{pH} \sim 7.0$. At the end of 21 days, it was observed a well-developed layer of periphyton attached to each glass slide. Once the slides were cultivated under the same conditions, they had the same amount of biofilm, with the same community composition prior to initiating the tests.

\section{Ecotoxicological tests}

After colonization in the aquarium, groups of seven glass slides were placed in $1.5 \mathrm{~L}$ plastic microcosms containing LC Oligo medium (Table I of Supplementary Material), divided in five treatments, each one in triplicate: $0.013 \mathrm{mg} \mathrm{Cu} \mathrm{L}-1,0.06 \mathrm{mg} \mathrm{Cu} \mathrm{L}-1,0.1 \mathrm{mg}$ $\mathrm{Cu} \mathrm{L-1}$, and $0.15 \mathrm{mg} \mathrm{Cu} \mathrm{L-1} \mathrm{and} \mathrm{a} \mathrm{control} \mathrm{(} 0 \mathrm{mg} \mathrm{Cu} \mathrm{L-1),} \mathrm{using} \mathrm{a} \mathrm{total} \mathrm{of} 15$ microcosms. The lowest $\mathrm{Cu}$ concentration was the same as that described for Class 3 water bodies in Brazilian legislation (CONSELHO NACIONAL DE MEIO AMBIENTE, 2016), and the maximal concentration was 10 times higher the maximum concentration allowed. Periphyton was exposed to $\mathrm{Cu}$ for two weeks in an incubator chamber (model 411FPD, Ethik), under the same lab conditions of illumination, $\mathrm{pH}$ and temperature employed for the aquarium culture. After this period, the samples were removed for analysis.

\section{Taxonomic characterization and ecological parameters}

Periphyton from one glass slide of each microcosm was collected using a soft brush and deionized water, than preserved in 10\% Lugol's iodine (for quantitative analysis) or $4 \%$ 
formalin (for qualitative analysis) as described by Yonghong (2016). Than the samples of each triplicate were combined, resulting in one sample for each treatment. Therefore, there was no replication of samples $(n=1)$, and the analysis were qualitative. The algal composition of periphyton was identified at species level, due to its higher representativeness in periphytic biofilm several identification guides were used as Bicudo and Menezes (2006), Franceschini (2013), Ludwig and Tremarin (2013), and Lamparelli et al. (2014). Quantitative procedures employed rarefaction curves (BICUDO, 1990), using at least 100 individuals of the most abundant species. The data were used to calculate the species richness, density, Shannon's diversity and distribution of different algae groups, for each concentration. Determination of the abundant species and the descriptive species at $2 \%$ of total density was also done (FELISBERTO \& RODRIGUES, 2012).

\section{Chlorophyll-a and ash-free dry mass}

For determination of chlorophyll-a (Chl-a) and ash-free dry mass (AFDM), biofilm of one glass slide was collected and filtered using glass fiber filters (AP40, Millipore). The Chl-a was extracted and quantified according to the methodology described by Torres et al. (2014). The filtered biofilm was macerated and extracted into $90 \%$ acetone, followed by centrifugation at $3000 \mathrm{rpm}$ for $15 \mathrm{~min}$. The absorbance of the supernatant was measured using a spectrophotometer (model B572, Micronal).

The AFDM was determined based on Roberts et al. (2014). The previously filtered biofilm was dried in an oven at $65^{\circ} \mathrm{C}$ until the weight stabilized. After obtaining the dry weight, the material was combusted in a muffle furnace $\left(450^{\circ} \mathrm{C}, 60 \mathrm{~min}\right)$ in order to obtain the ashes. The AFDM was obtained by subtracting the weight of the ash from the dry weight.

\section{Fluorescence measurements and light saturation curves}

Photosynthesis performance was measured by assessing the in vivo fluorescence of the Chl-a by using a Pulse Amplitude Modulation fluorometer (model PAM-2500, Waltz). The light fiber of the equipment was positioned over the glass slide containing the periphyton previously exposed to copper, followed by activation of the luminous pulse. Maximal quantum yield ( $\mathrm{Fv} / \mathrm{Fm})$ was estimated after acclimatization of 15 minutes in a dark condition (Kumar et al. 2014) and the effective quantum yield (YII) after the light pulse. Relative 
electron transport rate (rETR) was assessed after periphyton exposure to consecutive luminous pulses at different intensities within the photosynthetically active radiation (PAR) range (WEYER et al., 2010). Using this data, light saturation curves were built in order to find the light saturation point (Ik) for each treatment.

\section{Data analysis}

All the artwork seen in this work was created using OriginPro 8.5 (OriginLab). The same program was also used to analyze significant alterations between the treatments for AFDM, Chl-a, and fluorescence (YII and Fv/Fm) through one-way ANOVA followed by Tukey's test $-\mathrm{p}<0.05$ (POTVIN, 2001). The assumptions of normality and homoskedasticity were tested using Bartlett's test and Kolgomorov Smirnov's test, respectively.

A principal component analysis (PCA) was performed by using Past software (HAMMER, et al. 2001). This multivariate analysis brings out strong patterns in the dataset, correlating the biological and ecological parameters of the biofilm with the different treatments (Control, $0.013 \mathrm{mg} \mathrm{Cu} \mathrm{L}-1,0.06 \mathrm{mg} \mathrm{Cu} \mathrm{L}-1,0.1 \mathrm{mg} \mathrm{Cu} \mathrm{L}-1$, and $0.15 \mathrm{mg} \mathrm{Cu} \mathrm{L-1).} \mathrm{The} \mathrm{main}$ hypothesis of this analysis was to confirm that $\mathrm{Cu}$ contamination can be identified through differentiation in periphyton composition. The data of AFDM, Chl-a, YII, algal groups, descriptive species, diversity, species richness, dominance, density were transformed using Cox-Box transformations. Then, data was submitted by normality tests (Jarque-Bera, Saphiro Wilk and Anderson Darling) in order to check if they were suitable to PCA analysis. The results were displayed in a biplot.

\section{Results}

\section{Taxonomic characterization and ecological parameters}

In total, 50 species were identified (a complete table is available in Table II, Supplementary Material), in which considerable similarity in species richness $(\mathrm{N})$ and algal density was observed among the contaminated and control communities (Fig. 1). According to Shannon's diversity index, there was higher diversity in the control and $0.06 \mathrm{mg} \mathrm{Cu} \mathrm{L-1}$ treatments (1.98), when compared to the other concentrations (varying from 1.56 to 1.92). 
Figure 1: Species richness (N), Richness in common with control treatment and Algal density (ind $/ \mathrm{cm}^{2}$ x 104) after 15 days of copper exposure

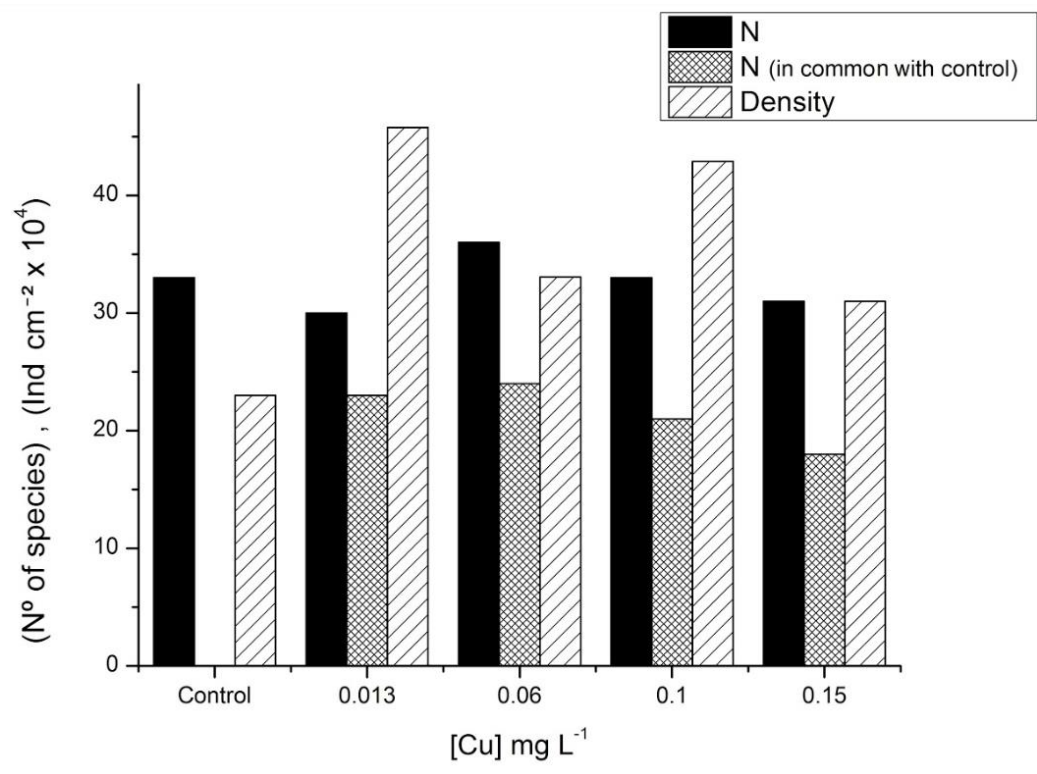

Quantitative evaluation showed that few species were better adapted to the environments containing copper (Fig. 2a), and comparisons among the treatments revealed alterations in biofilm composition, with a predominance of Cyanobacteria for all treatments (Fig. 2b). On this basis, only seven species out of the 50 identified were considered descriptive, as shown in Figure 2a. The cyanobacteria Pseudanabaena minima (G.S.An) Anagnostidis was the most abundant species in the control (45\%), $0.013 \mathrm{mg} \mathrm{Cu} \mathrm{L-1}$ (48\%), and $0.06 \mathrm{mg} \mathrm{Cu} \mathrm{L-1} \mathrm{(36 \% )} \mathrm{treatments} \mathrm{(Fig.} \mathrm{2a),} \mathrm{whereas} \mathrm{Planktolyngbya} \mathrm{limnetica}$ (Lemmermann) Komárková-Legnerová \& Cronberg was the most abundant species in the 0.1 mg Cu L-1 (45\%) and $0.15 \mathrm{mg} \mathrm{Cu} \mathrm{L-1} \mathrm{(47 \% )} \mathrm{treatments.} \mathrm{The} \mathrm{Chlorophyceae} \mathrm{Scenedesmus}$ ecornis (Ehrenberg) Chodat and the Cyanobacteria Phormidium foreaui (Frémy) Umezaki \& Watanabe were only descriptive for the control treatment. The Chlorophyceae Desmodesmus aculeolatus (Reinsch) P.M.Tsarenko was a descriptive species in the 0.06 and $0.15 \mathrm{mg} \mathrm{Cu} \mathrm{L-}$ 1treatments, but it was not identified in the control. Flagellated algae represented by Pteromonas sp. and Phacotus sp. were only identified in the contaminated samples, and not in the control. 
When the total species richness and diversity was divided by algal groups (Fig. 2b), there was a decrease in the number of Zygnemaphyceae individuals (Cosmarium sp., Gonatozygon tenuissimum Playfair, Mougeotia sp.), while at the same time the Cyanobacteria dominance was constant.

The Chlorophyceae representatives were affected by the copper contamination, with the exception of the $0.06 \mathrm{mg} \mathrm{Cu} \mathrm{L-1community} \mathrm{(Fig.} \mathrm{2b).} \mathrm{The} \mathrm{most} \mathrm{representative} \mathrm{green} \mathrm{alga}$ was Scenedesmus quadricauda (Turpin) Brébisson, which was a descriptive species in all the

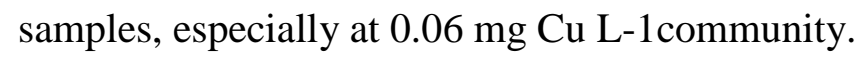


Figure 2: (a) Algal density of descriptive species in each treatment and (b) Algal density of each algal group for each treatment.

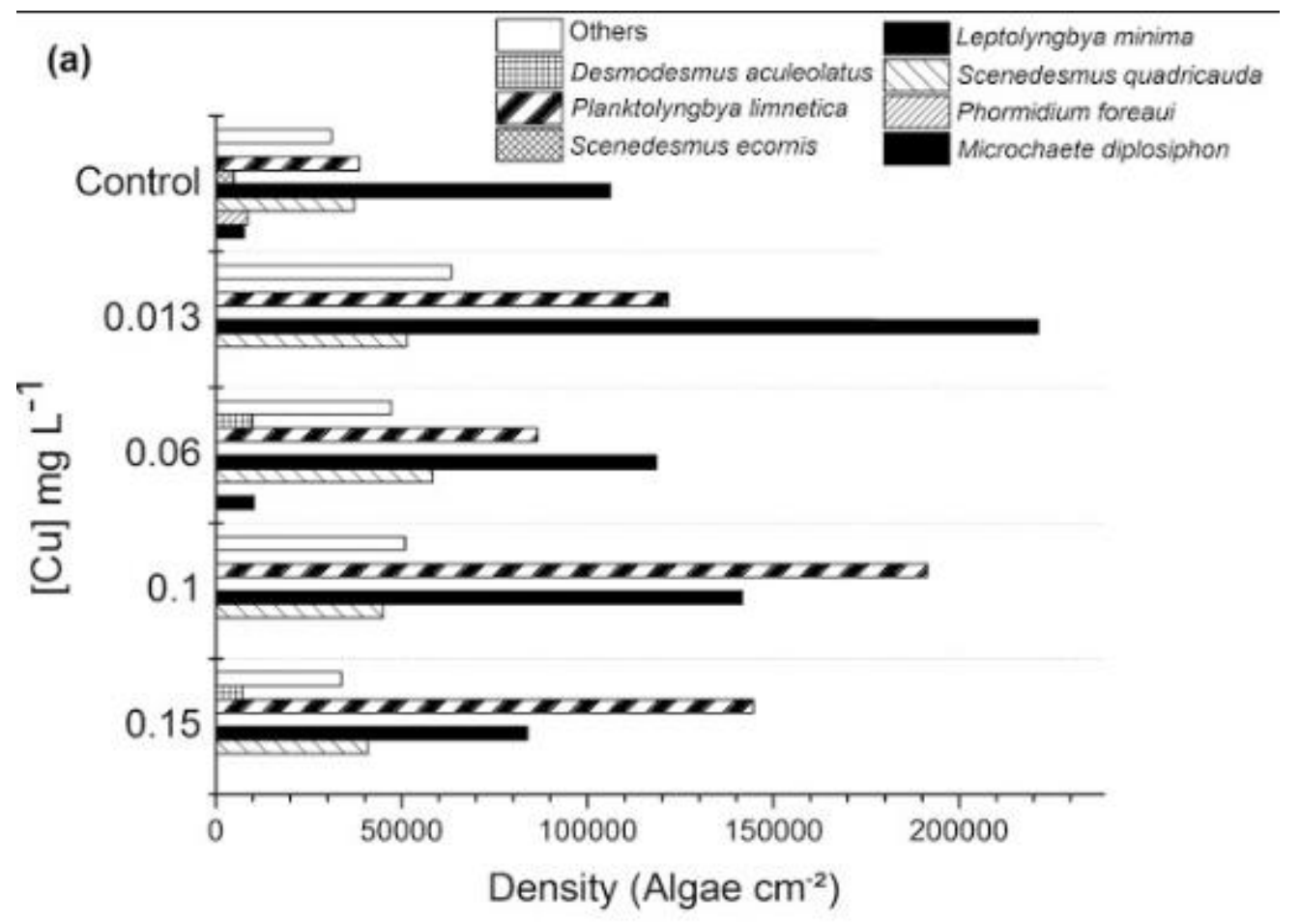

(b)

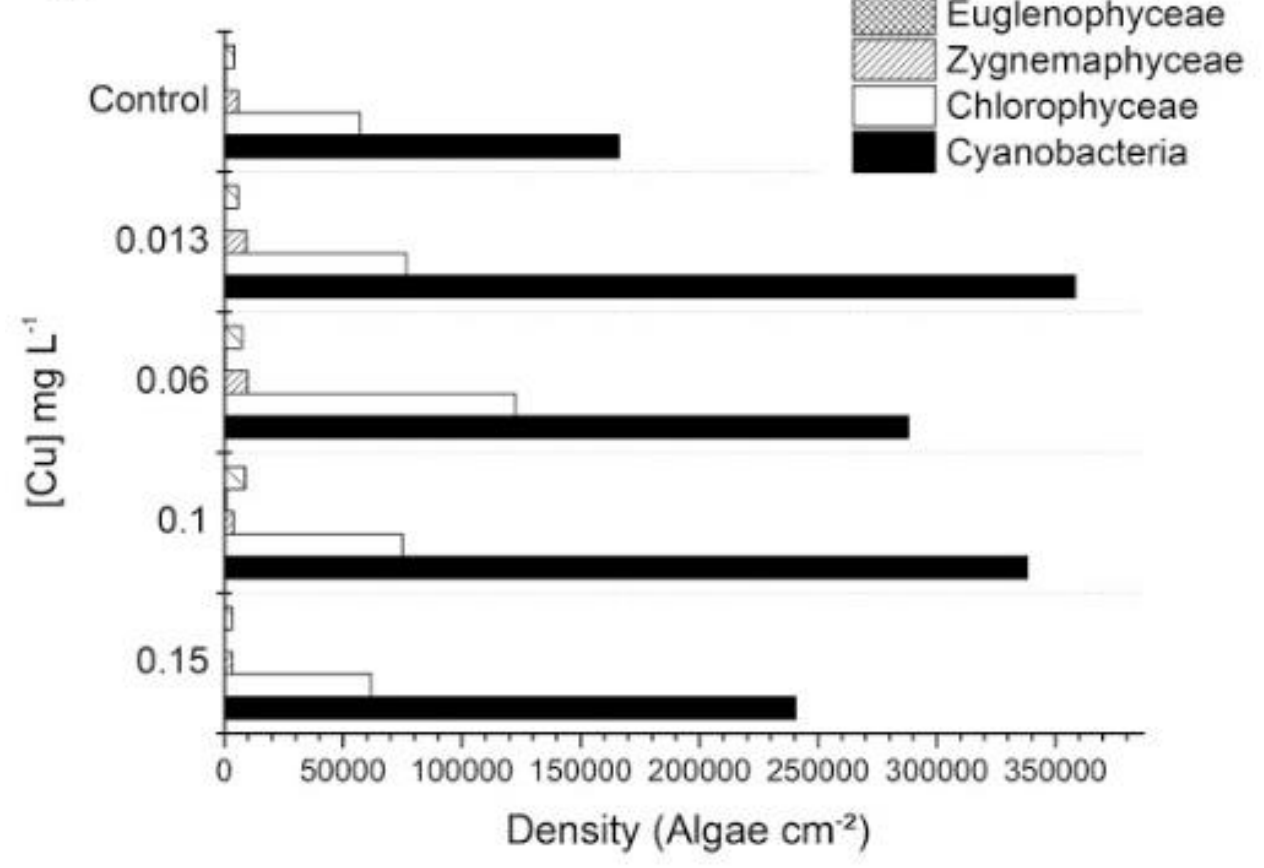




\section{Chlorophyll-a and AFDM}

In both Chlorophyll-a and AFDM contents, there was no significant difference between Control and Cu-treatments (Fig. 3a). However treatment $0.013 \mathrm{mg} \mathrm{Cu} \mathrm{L-1} \mathrm{was}$ significant higher than $0.15 \mathrm{mg} \mathrm{Cu} \mathrm{L-1.} \mathrm{Lavene's} \mathrm{test} \mathrm{however,} \mathrm{was} \mathrm{inconclusive} \mathrm{for}$ Chlorophyll-a data, which could compromise ANOVA results. But since all the other data groups were both normally distributed and homoscedastic, we assumed that ANOVA was a proper choice for analyzing all of them.

Fluorescence measurements and photosynthetic curves

Maximal quantum yield (Fv/Fm) exhibited higher chlorophyll fluorescence values (from 0.55 to 0.46 ) than the respective effective quantum yield [Y(II)] (from 0.53 to 0.34 ) at the same Cu-treatment (Fig. 3b). Even though there were no differences in Fv/Fm among the treatments and the Control, treatments 0.013 and $0.06 \mathrm{Cu} \mathrm{L-1}$ were significant higher than $0.15 \mathrm{mg} \mathrm{Cu} \mathrm{L-1.} \mathrm{As} \mathrm{for} \mathrm{Y(II),} \mathrm{there} \mathrm{were} \mathrm{no} \mathrm{significant} \mathrm{differences} \mathrm{in} \mathrm{any} \mathrm{case.}$

The light response curves (rETR x PAR) of the periphyton at different $\mathrm{Cu}$ concentrations are shown in Figure 3c. All maximal rETR (rETRmax) under the $\mathrm{Cu}$-treatments were saturated at similar PAR light intensity (around $110 \mu \mathrm{mol} \mathrm{m}-2 \mathrm{~s}-1$ ), in which three group of responses were highlighted: a major rETRmax at $0.1 \mathrm{Cu} \mathrm{Cu} \mathrm{L-1,} \mathrm{a} \mathrm{medium} \mathrm{rETRmax} \mathrm{including} 0.013$ and $0.06 \mathrm{mg} \mathrm{Cu} \mathrm{L-1}$ and a lower rETRmax at Control and $0.15 \mathrm{mg} \mathrm{Cu} \mathrm{L-1} \mathrm{(Fig.} \mathrm{3c).}$ 
Figure 3: Biological variation in periphyton after different copper treatments. (a) Differences of chlorophyll-a and ash-free dry mass - AFDM. (b) Maximum quantum yield (Fv/Fm) and effective quantum yield (YII) of the periphyton. (c) Photosynthetic light curves of the periphyton.
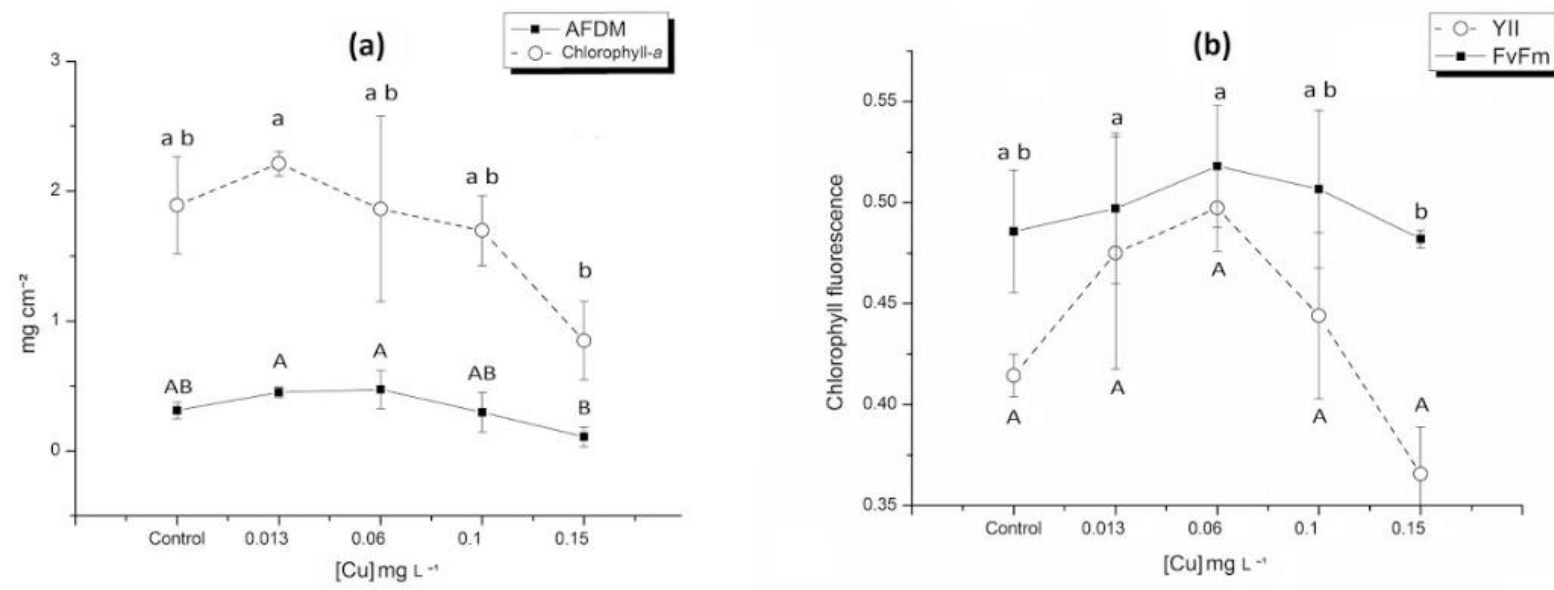

(c)

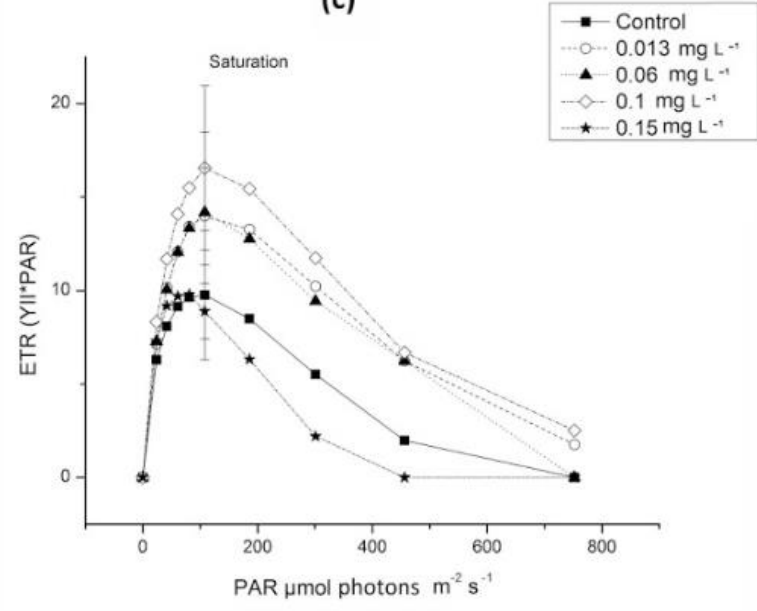

Principal component analysis (PCA)

The PCA results including the taxonomical, ecological and physiological variables and the concentration of $\mathrm{Cu}$ showed that the first component (PC1) accounted for $52.52 \%$ of the total variance in the data set, while the second component (PC2) explained $25.47 \%$ of the total variability (Fig. 4). The score of PC1 was positively correlated between Control and $0.06 \mathrm{mg}$ $\mathrm{Cu}$ L-1 treatment, represented by the variations of Chl-a, Y(II), AFDM, species richness, diversity and descriptive species matched by the correlation with the presence of diatoms, Zygnemaphyceae, Euglenophyceae and Chlorophyceae. 
Total density and dominance related to Cyanobacteria were correlated with the variability of the $\mathrm{Cu}$ concentration at $0.013 \mathrm{mg} \mathrm{Cu} \mathrm{L-1}$ and $0.1 \mathrm{mg} \mathrm{Cu} \mathrm{L-1} \mathrm{(Fig.} \mathrm{4),} \mathrm{with}$ positive correlation with the score of PC2. A distant representation variability was evidenced at the highest $\mathrm{Cu}$ concentration $(0.15 \mathrm{mg} \mathrm{Cu} \mathrm{L-1})$, which was positioned at negative scores of PC1 and PC2 and no vector correlations was observed. Ecological parameters (algal groups, species, richness, diversity, density) were more related to the effects of $\mathrm{Cu}$ contamination up to $0.1 \mathrm{mg} \mathrm{Cu} \mathrm{L}-1$. The higher concentration tested of $0.15 \mathrm{mg} \mathrm{Cu} \mathrm{L}-1$ however was related to the remaining physiological parameters (YII, AFDM, Chl-a).

Figure 4: A principal component analysis biplot diagram showing similarity relationships among 13 ecological and physiological variables and the treatments; scores of the treatments on the plane defined by Principal Component 1 (52.52\%) and Principal Component 2 (25.47\%). AFDM (Ash Free Dry Mass), Bac (Diatoms), Chl (Chlorophyceae), Chl-a (Chlorophyll-a), Cya (Cyanobacteria), Den (Density), Div (Diversity), Dom (Dominance), Eug (Euglenophyceae), Rich (Species richness), Spp (Descriptive species), Y(II) (effective quantum yield), Zyg (Zygnemaphyceae)

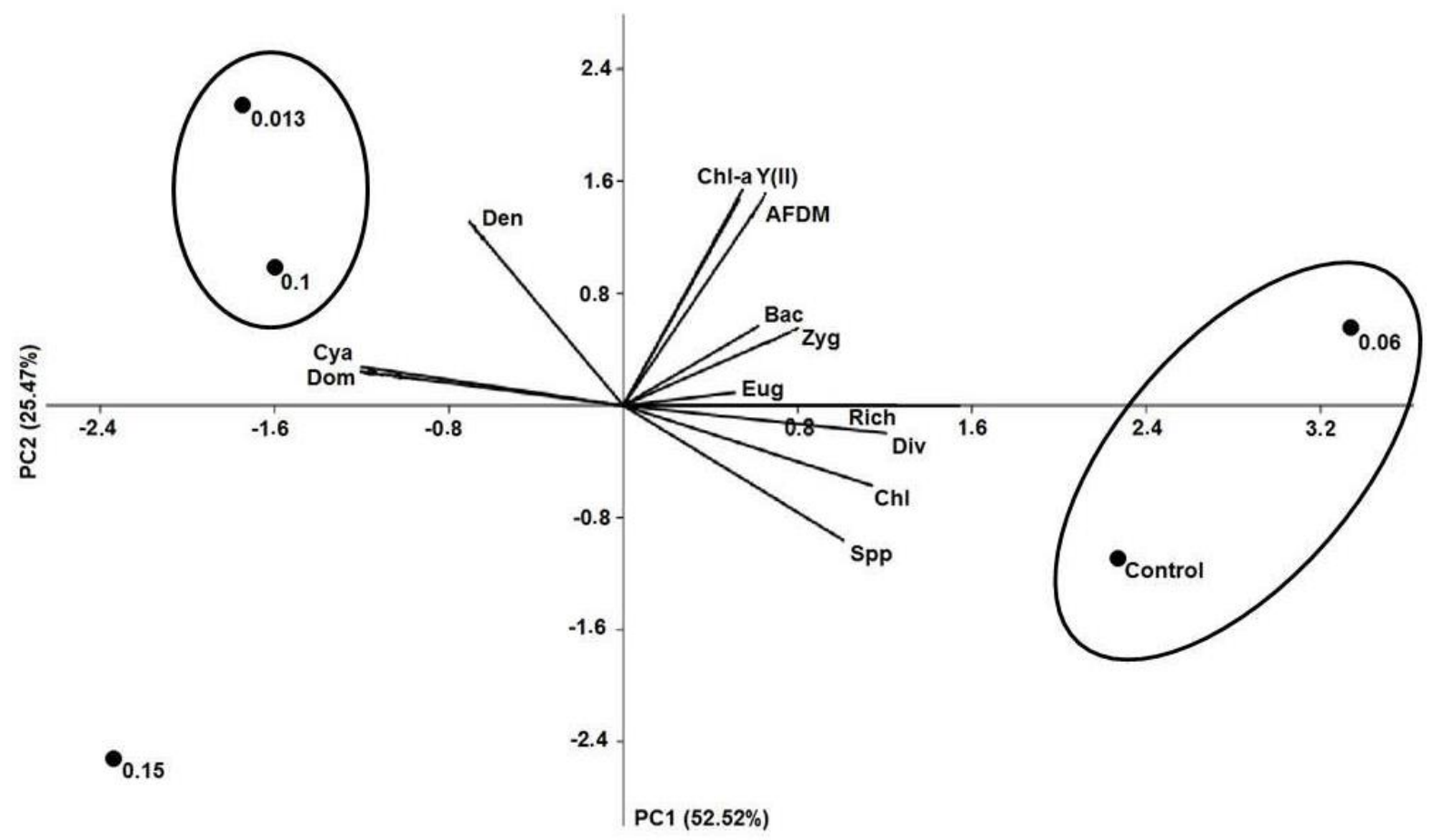




\section{Discussion}

According to Rouco et al. (2014), different algal groups such as Cyanobacteria and Chlorophyceae have dissimilar genetic and physiological tolerances to $\mathrm{Cu}$. For this reason, it was expected that the exposure to $\mathrm{Cu}$ would not cause instant collapse or high mortality in the periphyton, but rather a gradient of alterations in functioning and composition, as observed in this study. However, tolerance does not necessarily mean that all of the ecosystem functions provided by the periphyton are maintained in the presence of $\mathrm{Cu}$. Species better adapted to contamination may also be less successful in providing certain ecosystem services (REID \& TORRES, 2014). The pollution-induced community tolerance (PICT) parameter describes the degree of maintenance of periphyton functionality, following pressure due to exposure to a contaminant, considering an entire set of changes and adaptations caused in the community (LAMBERT et al., 2016). Such changes are influenced by the varying degrees of genetic adaptation and/or physiological limits of different groups (ROUCO et al., 2014), resulting in different levels of acclimation, sensitivity, and tolerance, arising from differences in gene expression among species.

The chemical behavior of copper must also be considered. Once in water copper can be affected by speciation process, reacting with other substances and forming compounds with lower bioavailability (TAKAMURA-ENYA \& TOKUTAKE, 2016). It affects directly the ecotoxicological results, once metals are generally toxic only when in free ion form, in this case, $\mathrm{Cu} 2+$ (BREAULT et al., 1996). This process is relevant in this study because the culture media used (L.C. Oligo) contains Citric Acid (Table I of Supplementary Material), a metal chelator. According to Hamada et al. (2015) in water solutions coppers reacts with Citric Acid forming $\mathrm{Cu} 2+-$ Citrate complexes, decreasing the bioavailability to periphyton, although it stills accumulates in its mucilage (SOUSA et al., 2017). This way, the effects of speciation would be more severe on experiments with low copper:citric acid ratio, in this case the treatment of $0.013 \mathrm{mg} \mathrm{Cu} \mathrm{L-1,} \mathrm{with} \mathrm{a} \mathrm{ratio} \mathrm{near} \mathrm{to} 1: 1$. According to a degradation study of Kabra et al. (2008), in a similar situation 1:1 ratio the speciation of copper can reach up to $47 \%$. When copper is more abundant than citric acid (treatments of $0.06 \mathrm{mg} \mathrm{Cu} \mathrm{L-1,0.1 \textrm {mg }}$ and $0.15 \mathrm{mg} \mathrm{Cu} \mathrm{L-1),} \mathrm{the} \mathrm{effects} \mathrm{of} \mathrm{speciation} \mathrm{are} \mathrm{more} \mathrm{subtle.} \mathrm{In} \mathrm{field} \mathrm{studies} \mathrm{speciation} \mathrm{is}$ normally observed in contaminated environments, with copper reacting with organic acids or anthropogenic compounds such as ethylenediaminetetraacetic - EDTA (TAKAMURAENYA \& TOKUTAKE, 2016). Therefore, it is not indicated to compare the effects of copper 
shown in this study directly with field conditions. Since speciation can occur in different ways, depending on the chemical composition of where periphyton is inserted, a direct correlation of data needs also the same level of speciation. This way, the focus of this study was to examine the patterns caused by copper contamination in different algal groups, considering that both field and laboratory conditions go through different chemical process, so which can lead to different final results between them.

With that in mind, it was observed a clear dominance of cyanobacteria (over $50 \%$ of the total individuals), as expected and in agreement with the low light saturation points shown in the photosynthetic curves. A predominance of filamentous forms is typical when periphyton is at an advanced stage in succession (DUNCK et al., 2015), and cyanobacteria are well adapted to high temperatures (FERNANDÉZ et al., 2015). Despite the fact that copper sulphate is widely used as an algicide, including in the upper Tietê river basin in São Paulo State (BEGUELLI et al., 2015), Planktolyngbya and Pseudanabaena are common to the local flora in the São Paulo reservoirs (LAMPARELLI et al., 2014) and were the most abundant algae identified in this study. Consequently, these tolerant species could actually become more abundant and cause blooms, if exposed to higher concentrations of $\mathrm{Cu}$. The decrease of P. minima abundance and subsequent increase of $\mathrm{P}$. limnetica, at higher $\mathrm{Cu}$ concentrations, could be explained by the presence of the external mucilage matrix. Mucilage is a known mechanism of defence of cyanobacteria species against metal poisoning (REYNOLDS, 2007) and is found in large amounts in P. limnetica, but not in P. minima. The presence of this matrix therefore represents a competitive advantage for P. limnetica in metal-contaminated environments, and here this species was the most abundant at 0.1 and $0.15 \mathrm{mg} \mathrm{Cu} \mathrm{L-1}$. Given the common dominance of cyanobacteria in periphyton communities, together with the fact that $\mathrm{Cu}$ is non-biodegradable and is bioaccumulated in many organisms, and that the most contaminated samples analyzed in this study showed substantial layers of mucilage, it could be argued that periphyton dominated by cyanobacteria may present intensified bioaccumulation processes, as suggested by Yonghong et al. (2014). Mucilage has been also related to defence against predators, since it reduces the palatability of the algae. Hence, the higher abundance of non-palatable algae in periphyton may harm the food chain, even when the total primary production is the same, due to asynchrony in ecological functionality and composition among the organisms, caused by the $\mathrm{Cu}$-triggered disturbance (DOWNING et al., 2014). 
The decrease of Chlorophyceae after $0.06 \mathrm{mg} \mathrm{Cu} \mathrm{L-1,} \mathrm{with} \mathrm{its} \mathrm{replacement} \mathrm{by} \mathrm{less}$ palatable filamentous cyanobacteria (BURLIGA, 2010), was indicative of harm to the ecosystem in the short term. The group was mainly represented by genera Desmodesmus and Scenedesmus, which according to Bodini et al. (2018), are very important for oligotrophic food chains, especially if compared to the Cyanobacteria species abundant in the samples. So changes in its abundance have direct effects on the carbon flux. Furthermore, even positive changes, such as the initial enhancement of green algae up to $0.06 \mathrm{mg} \mathrm{Cu} \mathrm{L-1}$, do not necessarily reflect a beneficial alteration. The reason behind it, is that periphyton accumulates $\mathrm{Cu}$ when exposed to it (SERRA et al., 2009; HOANG et al., 2011). Therefore, the presence of a contaminated and palatable biomass, such as $S$. quadricauda, Phacotus sp. or Pteromonas $s p$. (BURLIGA, 2010), can potentially result in damage for its consumers, due to copper toxicity.

When referring to changes in descriptive species, both S. ecornis and P. foreaui were only descriptive for the control sample, even though they are considered cosmopolitan and highly adaptable to a wide range of environmental conditions (FRANCESCHINI et al., 2010). In this study, their presence in the biofilm was significantly affected by the $\mathrm{Cu}$ contamination. The species D. aculeolatus was descriptive for the 0.06 and $0.15 \mathrm{mg} \mathrm{Cu} \mathrm{L-1} \mathrm{samples,} \mathrm{but} \mathrm{was}$ not even identified in the control, showing a clear replacement between evolutionally close genera (GORELOVA et al., 2015).

Other changes can be explained due to different competitive strategies between algae groups. According to Serra et al. (2009), diatoms are poorer competitors than Cyanobacteria and Chlorophyceae in the presence of $\mathrm{Cu}$. This was supported by the fact that three out of the five species identified only in the control sample were diatoms. Once diatoms are highly consistent bioindicators (SMUCKER et al., 2013), changes in their abundance are a common sign of contamination. The Zygnemaphyceae species identified here were generally kstrategists that are competitive in mesotrophic and stable ecosystems (SOUZA et al., 2015). This group was adversely affected by the exposure to copper and was slowly replaced by filamentous forms with faster growth rates, which are naturally more competitive in periphyton (BURLIGA, 2010). Since the $\mathrm{Cu}$ contamination caused several changes in community composition and structure, ecological parameters were more suitable for explaining the differences between the concentrations.

Considering the physiological impacts of $\mathrm{Cu}$ on the periphyton, it was observed that the changes in AFDM and Chlorophyll-a were compatible with the taxonomic alterations 
evidenced above, however more subtle. The presence of $\mathrm{Cu}$ at $0.15 \mathrm{mg} \mathrm{Cu} \mathrm{L-1}$ resulted in a significantly lower concentration of Chl-a, as well as lower AFDM production, which could be explained by the high dominance of Cyanobacteria and lower density in this specific treatment, compared to the control. According to Lan et al. (2018), variations in Chl-a concentration among different treatments, as shown here in Fig. 3a, reflect stages of adaptation of the periphyton to $\mathrm{Cu}$ exposure, which is a response that is more related to acclimation mechanisms. When analyzing the initial concentrations $(0.013 ; 0.06 \mathrm{mg} \mathrm{Cu} \mathrm{L-1})$, there was no significant variation of AFDM and Chl-a. This indicates that the capacity of the biofilm in adapting its composition under copper contamination (BLANCK, 2002) is higher than the decrease in primary production caused by the same situation. However, these structural changes are considerable enough to affect the consumers of periphyton.

The composition of the community also affected the values of YII and Fv/Fm. Normally, the species that compose the periphyton community present low Fv/Fm and YII, since they require small levels of energy for supplying photosynthesis, so the community does not need to use its maximum energy potential. Physiological adaptations, such as being able to use photosynthetic rates close to the maximum potential ( $\mathrm{YII}=\mathrm{Fv} / \mathrm{Fm}$, as shown in Fig. $3 b$ ) were observed for the samples from 0.13 to $0.1 \mathrm{mg} \mathrm{Cu} \mathrm{L-1,} \mathrm{suggesting} \mathrm{that} \mathrm{exposure} \mathrm{to}$ $\mathrm{Cu}$ contamination resulted in a physiological necessity for metabolic enhancement in the communities (RETKUTE et al., 2015). At higher $\mathrm{Cu}$ concentration, however, YII was significantly lower. According to Kumar et al. (2014), there are several possible reasons for a decrease in YII, including environmental conditions, contamination, and age. Furthermore, it is usual that in a complex community such as periphyton, different algal groups (such as cyanobacteria or green algae) have different fluorescence values, since the antenna complex and chlorophyll a levels differ among the phyla and species (HEINZ-WALZ, 2003). Consequently, taxonomic and environmental differences in communities can result in different fluorescence values. Tolerance varies according to physiological adaptations and the selection of tolerant species instead of sensitive ones (BLANCK, 2002). Toxicity assays have shown that periphyton has considerable resistance to metals (YONGHONG, 2016). Here, the significantly lower YII values for the highest $\mathrm{Cu}$ concentration indicated that the community had acquired a structure better adapted to $\mathrm{Cu}$ contamination. This was confirmed by the Fv/Fm values, which were statistically similar for all the treatments, even $0.15 \mathrm{mg} \mathrm{Cu} \mathrm{L-1.} \mathrm{In}$ the case of harm due to sensitivity to $\mathrm{Cu}$, there would be a noticeable decrease of $\mathrm{Fv} / \mathrm{Fm}$, indicative of cellular damage. 
The wavelength $(\lambda)$ of the photosynthetic curve for the $0.15 \mathrm{mg} \mathrm{Cu} \mathrm{L-1} \mathrm{sample} \mathrm{was}$ smaller than for the other curves obtained in this study, indicating a more specific functional condition and faster photoinhibition (LEI et al., 2015). Since only a fraction of light is absorbed and used by algae, rapid attainment of a light saturation level by the community could indicate that the light is underused, supporting a low primary production (WEYER et al., 2010). The maximum saturation level corresponds to the intensity at which the maximum ETR occurs.

After this point, lower values reflect photoinhibition by the increasing light intensity. Therefore, a lower initial slope (photosynthetic efficiency) of a photosynthetic curve indicates that the community requires a more specific PAR interval for perfect functioning (LEI et al., 2015). According to Hill (1996), the photosynthetic curve for a community is composed of the sum of the individual curves for the different species. Since these curves are overlapped, this results in an overview of the functioning of the community (DEVLIN et al., 2016). Variations in the photosynthetic efficiency or amplitude of the initial slope are linked to stress conditions, changes in taxonomic composition, and altered biomass production (LEI et al., 2015). In addition, according to Karlsson et al. (2009), higher values of PAR saturation in primary producers lead to enhanced production of biomass in consumers such as fishes.

A community with dominance of cyanobacteria presents a saturation range between 100 and $400 \mu \mathrm{mol} \mathrm{m}-2 \mathrm{~s}-1$ (HILL, 1996). However, when exposed to $0.15 \mathrm{mg} \mathrm{Cu} \mathrm{L}-1$, ETRmax occurred at $81 \mu \mathrm{mol} \mathrm{m}-2 \mathrm{~s}-1$, below the level common even for cyanobacteria.

In the PCA analysis, our main hypothesis was to identify the control and $0.06 \mathrm{mg} \mathrm{Cu}$ L-1 treatments were clustered together, due to higher Chlorophyceae density and diversity. Other parameters were only able to explain the $\mathrm{Cu}$ effects when the contamination was sufficiently high to cause physiological effects in the biofilm. Even though all the physiological parameters are also connected to the composition of the community, it is important to observe the pattern shown in the PCA biplot. The $0.15 \mathrm{mg} \mathrm{Cu} \mathrm{L}-1$ treatment, which was clustered with lower values for Chl-a concentration, AFDM, YII, and light saturation point, was positioned apart from the other treatments. These results showed that this concentration, which is easily found in contaminated reservoirs (RICHTER et al., 2007), was able to effectively modify the periphytic community (in comparison to the situation found for the control), hence initiating a cascade effect in the aquatic ecosystem. 


\section{Conclusions}

Exposure of the periphyton to different $\mathrm{Cu}$ concentrations resulted mainly in ecological alterations. Cyanophyceae was dominant in all treatments, with higher concentrations of $\mathrm{Cu}$ impacting Chlorophyceae, diatoms and Zygnemaphyceae. There was a replacement of less well adapted species such as k-strategists by more unpalatable and mucilaginous species as well the decrease of biomass production (in $0.15 \mathrm{mg} \mathrm{Cu} \mathrm{L-1}$ samples), which restricts predation by zooplankton. The results of the photosynthetic curve, AFDM, and YII analyses showed that exposure of the biofilm to different $\mathrm{Cu}$ concentrations led to a certain selective pressure, depending on the concentration. However, those results were less apparent than the ecological ones.

PCA results showed that $\mathrm{Cu}$ caused a diversification on periphyton composition. At highest concentration, physiological parameters were more suitable to explain the $\mathrm{Cu}$ effects, on the other hand, in lower concentrations ecological parameters were more satisfactory in explaining the contamination.

The present findings demonstrated that periphyton when contaminated with $\mathrm{Cu}$, leads to a less palatable and smaller biomass, which is harmful to the food chain.

\section{Acknowledgments}

This work was supported by the scholarship CAPES (Finance code 001) and the FAPESP research grant (2014/22581-8). Special thanks to Cristiano Venícius de Matos Araújo (Instituto de Ciencias Marinas de Andalucía) for helpings us in revising this manuscript. Fungyi Chow thanks CNPq for the productivity fellowship (303937/2015-7).

\section{References}

ASSOCIAÇÃO BRASILEIRA DE NORMAS TÉCNICAS. Ecotoxicologia aquática toxicidade crônica - método de ensaio com algas (Chlorophyceae) - Normativa NBR 12648:2018. Brasília, 2019. Disponível em: http://www.abntcatalogo.com.br/norma.aspx?ID=391089. Acessado em 1.3.2019.

BEGHELLI, F.G.S.; ROSA, A.H.; NISHIMURA, P.Y.; MEIRINHO, P.A.; LEONARDI, B.F.; GUIDUCE, F.S.; LOPEZ-DOVAL, J.C.; POMPÊO, M.L.M.; MOSCHINI-CARLOS, V. Aplicações de sulfato de cobre no reservatório Guarapiranga: distribuição no meio e 
efeitos sobre a comunidade plantônica. In: POMPÊO, M.L.M.; MOSCHINI-CARLOS, V.; NISHIMURA, P.H.; CARDOSO-SILVA, S.; LÓPEZ-DOVAL, J.C. (Eds) Ecologia de reservatórios e interfaces, $1^{\mathrm{a}}$ ed. São Paulo: Universidade de São Paulo, 2015. p. 294-308.

BICUDO, C.E.M. Metodologia para o estudo qualitativo do perifíton. Acta Limnologica Brasilica, v. 3, n. 1, p. 447-491, 1990.

BICUDO, C.E.M.; MENEZES, M. Gêneros de algas continentais no Brasil: guia para identificação e descrições. 1. ed. São Carlos: Rima, 2006. 522 p.

BLANCK, H. A critical review of procedures and approaches used for assessing pollutioninduced community tolerance (PICT) in biotic communities. Human and Ecological Risk Assessment: An International Journal, Amherst, v. 8, n. 1, p. 1003-1034, 2002. https://doi.org/10.1080/1080-700291905792

BODINI, A.; BONDAVALLI, C.; ROSSETTI, G. Ecological succession investigated through food-web flow network. In: MOORE, J.C.; RUITER, P.C.; MCCANN, K.S.; WOLTERS, V. (Eds) Adaptive food webs - stability and transitions on real model ecosystems, $1^{\mathrm{a}}$ ed, Cambridge: Cambridge University Press, 2018. p. 164-177.

BREAULT, R.F.; COLMAN, J.A.; AIKEN, G.R.; MCKNIGHT, D. Copper speciation and binding by organic matter in copper-contaminated streamwater. Environmental Science and Technology, Washington, v. 30, n. 12, p. 3477-3486, 1996.

BURLIGA, A.L. Abordagem de grupos funcionais em estudos do perifíton e fitoplâncton. In: FRANCESCHINI, I.M.; BURLIGA, A.L.; REVIERS, B.; PRADO, J.F.; RÉZIG, S.H. (Eds.) Algas: uma abordagem filogenética, taxonômica e ecológica, $2^{\mathrm{a}}$ ed., São Paulo: Artmed, 2010. p. 234-258.

COMPANHIA AMBIENTAL DO ESTADO DE SÃO PAULO. Relatório de qualidade das águas interiores no estado de São Paulo em 2017. São Paulo: Secretaria de Meio Ambiente, 2017. Disponível em <https://cetesb.sp.gov.br/aguas-interiores/publicacoes-e-relatorios/>. Acessado em 10 de Abril de 2019.

CONSELHO NACIONAL DE MEIO AMBIENTE Resolução 357. Ministério do Meio Ambiente, Brasília. Disponível em: [http://www.mma.gov.br/port/conama/res/res05/res35705.pdf]. Acessado em 28.5.2019.

DEVLIN, S.P.; ZANDEN, M.J.V.; VADEBONCOEUR, Y. Littoral-benthic primary production estimates: sensitivity to simplifications with respect to periphyton productivity and basin morphometry. Limnology and Oceanography Methods, v. 14, n. 1, p. 138-149, 2016. https://doi.org/10.1002/lom3.10080

DOWNING, A.L.; BROWN, B.L.; LEIBOLD, M.A. Multiple diversity-stability mechanisms enhance population and community stability in aquatic food webs. Ecology, v. 95, n. 1, 173184, 2014. https://doi.org/10.1890/12-1406.1

DUNCK, B.; RODRIGUES, L.; BICUDO, D.C. Functional diversity and functional traits of periphytic algae during a short-term successional process in a neotropical floodplain lake. 
Brazilian Journal of Biology, São Carlos, v. 75, n. 1, p. 587-597, 2015. https://doi.org/10.1016/j.ecolind.2016.02.060

FELISBERTO, S. A.; MURAKAMI, E. A. Papel do Perifíton na ciclagem de nutrientes e na teia trófica. In: SHAWARZBOLD, A.; BURLIGA, A. L.; TORGAN, L. C. (Eds) Ecologia do Perifíton. São Carlos : Rima, 2013, p. 23-44.

FELISBERTO, S.A.; RODRIGUES, L. Dinâmica sucessional de comunidade de algas perifíticas em um ecossistema lótico subtropical. Rodriguésia, v. 63, n.1, p. 463-473, 2012.

FERNÁNDEZ, C.; ESTRADA, V.; PARODI, E.R. Factors triggering cyanobacteria dominance and succession during blooms in a hypereutrophic drinking water supply. Water Air and Soil Pollution, v. 226, n. 1, p. 73, 2015. https://doi.org/10.1007/s11270-014-2290-5

FRANCESCHINI, I.M. Chave de identificação dos gêneros de algas (exceto Bacillariophyceae) comumente encontrados no perifíton e metafíton de ambientes aquáticos continentais. In: SCHWARZBOLD, A.; BURLIGA, A.L.; TORGAN, L.C. (Eds). Ecologia do perifíton, $1^{a}$ ed., São Carlos: Rima, 2013. p. 245-266.

FRANCESCHINI, I.M.; PRADO, J.F.; BURLIGA, A.L. Diversidade. In: FRANCESCHINI, I.M.; BURLIGA, A.L.; REVIERS, B.; PRADO, J.F.; RÉZIG, S.H. (Eds) Algas: uma abordagem filogenética taxonômica e ecológica, $2^{\mathrm{a}}$ ed., São Paulo: Artmed, 2010. p. 73 213.

GAISER, E.E.; ANDERSON, E.P.; CASTAÑEDA-MOYA, E.; COLLADO-VIDES, L.; FOURQUREAN, J.W.; HEITHAUS, M.R.; JAFFE, R.; LAGOMASINO, D.; OEHM, N.J.; PRICE, R.M.; RIVERA-MONROY, V.H.; CHOWDARY, R.R.; TROXLER, T.G. New perspectives on an iconic landscape from comparative international long-term ecological research. Ecosphere, v. 6, n. 10, p. 1-18, 2015. https://doi.org/10.1890/ES14-00388.1

GARCÍA-VILLADA，L.; RICO, M.; ALTAMIRANO, M.; SÁNCHEZ-MARTÍNA, L.; LÓPEZ-RODAS, V.; COSTAS, E. Occurrence of copper resistant mutants in the toxic cyanobacteria Microcystis aeruginosa: characterisation and future implications in the use of copper sulphate as algaecide. Water Research, v. 38, n. 8, p. 2207-2213, 2004. https://doi.org/10.1016/j.watres.2004.01.036

GORELOVA, O.A.; BAULINA, O.I.; SOLOVCHENKO, A.E.; CHEKANOV, K.A.; CHIVKUNOVA, O.B.; FEDORENKO, T.A.; LOBAKOVA, E.S. Similarity and diversity of the Desmodesmus spp. microalgae isolated from associations with White sea invertebrates. Protoplasma, v. 252, n. 2, p. 489-503, 2015. https://doi.org/10.1007/s00709-014-0694-0

HAMADA, Y.Z.; COX, R.; HAMADA, H. Cu2+-Citrate dimer complexes in aqueous solutions. Journal of Basic and Applied Sciences, Ontario, v. 11, n. 1, p. 583-589, 2015. https://doi.org/10.6000/1927-5129.2015.11.78

HAMMER, Ø.; HARPER, D.A.T.; RYAN, P.D. PAST: paleontological statistics software package for education and data analysis. Palaeontologia Electronica, v. 4, n. 1, p. 1-9, 2001. 
HEGEWALD, H.; BRABAND, A. A taxonomic revision of Desmodesmus serie Desmodesmus (Sphaeropleales, Scenedesmaceae). Fottea, Prague, v. 17, n. 2, p. 191-208, 2017. https://doi.org/10.5507/fot.2017.001

HEINZ WALZ GMBH. Phytoplankton Analyzer PHYTO-PAM and Phyto-Win Software V 1.45 system components and principles of operation. Heinz Walz Gmbh, 2003. Disponível em [http://www.walz.com/downloads/manuals/phyto-pam/phyto_4e.pdf], Acessado em 30.5.19.

HILL, W. Effects of light. In: STEVENSON, R.J.; BOTHWELL, M.L.; LOWE, R.L. (Eds.) Algal ecology: freshwater benthic systems. London: Academic Press, 1996. p. 121-148.

HOANG, T.C.; PRYOR, R.L.; RAND, G.M.; FRAKES, R.A. Bioaccumulation and toxicity of copper in outdoor freshwater microcosms. Ecotoxicology and Environmental Safety, v. 74, n. 4, p. 1011-1020, 2011. https://doi.org/10.1016/j.ecoenv.2011.01.015

HOMMEN, U.; KNOPF, B.; RÜDEL, H.; SCHÄFERS, C.; GARMAN, E.R.; SCHAMPHELAERE, K.; SCHLEKAT, C. A microcosm study to support aquatic risk assessment of nickel: community-level effects and comparison with bioavailabilitynormalized species sensitivity distributions. Environmental Toxicology and Chemistry, Toronto, v. 35, n. 5, p. 1172 -1182, 2016. https://doi.org/10.1002/etc.3255

KABRA, K.; CHAUDHARY, R.; SAWHNEY, R.L. Solar photocatalytic removal of Cu(II), $\mathrm{Ni}(\mathrm{II}), \mathrm{Zn}(\mathrm{II})$ and $\mathrm{Pb}(\mathrm{II})$ : Speciation modeling of metal-citric acid complexes. Journal of $\begin{array}{llllllll}\text { Hazardous Materials, } & \text { v. } 155, \quad \text { n. } & 3, & \text { p. } & 424-432, & \end{array}$ https://doi.org/10.1016/j.jhazmat.2007.11.083

KARLSSON, J.; BYSTRÖN, P.; ASK, J.; PERSSON, L.; JANSSON, M. Light limitation of nutrient-poor lake ecosystems. Nature, v. 460, n. 1, p. 506-510, 2009. https://doi.org/10.1038/nature08179

KUMAR, K.S.; DAHMS, H.U.; LEE, J.S.; KIM, H.C.; LEE, W.C.; SHIN, K.H. Algal photosynthetic responses to toxic metals and herbicides assessed by chlorophyll a fluorescence. Ecotoxicology and Environmental Safety, v. 104, n. 1, p. 51-71, 2014. https://doi.org/10.1016/j.ecoenv.2014.01.042

LAMPARELLI, M.C.; TUCCI, A.; SANT'ANNA, C.; PIRES, D.A.; LERCHE, L.H.M.; CARVALHO, M.C.; ROSAL, C. Cianobactérias da região do Alto Tietê. São Paulo: CETESB, 2014. 96 p.

LAMBERT, A.S.; DABRIN, A.; MORIN, S.; GAHOU, J.; FOUQUIER, A.; COQUERY, M.; PESCE, S. Temperature modulates phototrophic periphyton response to chronic copper exposure. Environmental Pollution, Amsterdam, n. 208, v. (pt b), p. 821-829, 2015. https://doi.org/10.1016/j.envpol.2015.11.004.

LAN, M.; FENGWU, W.; YUANCHUN, Y.; JUNZHUO, L.; YONGHONG, W. Cu removal and response mechanisms of periphytic biofilms in a tubular bioreactor. Bioresource Technology, v. 248, n. b, p. 61-67, 2018. https://doi.org/10.1016/j.biortech.2017.07.014 
LEAL， P.R.; MOSCHINI-CARLOS， V.; LÓPEZ-DOVAL， J.C.; CINTRA， J.P.; YAMAMOTO, J.K.; BITENCOURT, M.D.; SANTOS, R.F.; ABREU, G.C.; POMPÊO, M.L.M. Impact of copper sulfate application at an urban Brazilian reservoir: A geostatistical and ecotoxicological approach. Science of the Total Environment, v. 618, n. 1, p. 621-634, 2018. https://doi.org/10.1016/j.scitotenv.2017.07.095

LEGUAY, S.; LAVOIE, I.; LEVY, J.L.; FORTIN, C. Using biofilms for monitoring metal contamination in lotic ecosystems. Environmental Toxicology and Chemistry, Toronto, v. 35, n. 6, p. 1489-1501, 2016. https://doi.org/10.1002/etc.3292

LEI, X.; CRUZ, J.A.; SAVAGE, L.J.; KRAMER, D.M.; CHEN, J. Plant photosynthesis phenomics data quality control. Bioinformatics, Oxford, v. 31, n. 11, p. 1796-1804, 2015. https://doi.org/10.1093/bioinformatics/btu854

LOPEZ, A.R.; FUNK, D.H.; BUCHWALTER, D.B. Arsenic (V) bioconcentration kinetics in freshwater macroinvertebrates and periphyton is influenced by $\mathrm{pH}$. Environmental Pollution, v. 224, n. 1, p. 82-88, 2017. https://doi.org/10.1016/j.envpol.2016.12.066

LUDWIG, T.A.V.; TREMARIN, P.I. Chave de identificação dos gêneros de diatomáceas (Diatomae-Ochrophyta) comumente encontrados no perifíton e metafíton de ambientes aquáticos continentais. In: SCHWARZBOLD, A.; BURLIGA, A.L.; TORGAN, L.C. (Eds). Ecologia do Perifíton, $1^{a}$ ed., São Carlos: Rima, 2013. p. 267-330.

OLIVER, S.L.; RIBEIRO, H. Variabilidade climática e qualidade de água no reservatório de Guarapiranga. Estudos Avançados, São Paulo, v. 28, n. 82, p. 95-128, 2014. http://dx.doi.org/10.1590/S0103-40142014000300007

POMPÊO, M.; PADIAL, P.R.; MARIANI, C.F.; CARDOSO-SILVA, S.; MOSCHINICARLOS, V.; SILVA, D.C.V.R.; PAIVA, T.C.B.; BRANDIMARTE, A.L. Biodisponibilidade de metais no sedimento de um reservatório tropical urbano (reservatório Guarapiranga - São Paulo (SP), Brasil): há toxicidade potencial e heterogeneidade espacial? Geochimica Brasiliensis, São Paulo, v. 27, n. 2, p. 104-119, 2013. https://doi.org/10.21715/gb.v27i2.364

POTVIN, C. ANOVA: experimental layout and analysis. In: SCHNEIDER, S.M.; GUREVITCH, J. (Eds) Design and analysis of ecological experiments. $2^{\mathrm{a}}$ ed, New York: Oxford university press, 2001. p. 63-77.

REID, B.; TORRES, R. Didymosphenia geminata invasion in South America: Ecosystem impacts and potential biogeochemical state change in Patagonian rivers. Acta Oecologica, v. 54, n. 1 , p. 101-109, 2014. https://doi.org/10.1016/j.actao.2013.05.003

RETKUTE, R.; SMITH-UNNA, S.E.; SMITH, R.W.; BURGESS, A.J.; JENSEN, O.E.; JOHNSON, G.N.; PRESTON, S.P.; MURCHIE, E.H. Exploiting heterogeneous environments: does photosynthetic acclimation optimize carbon gain in fluctuating light? Journal of Experimental Botany, London, v. 66, n. 9, p. 2437-2447, 2015 https://doi.org/10.1093/jxb/erv055 
REYNOLDS, C.S. Variability in the provision and function of mucilage in phytoplankton: facultative responses to the environment. Hydrobiologia, v. 578, n. 1, p. 37-45, 2007. http://dx.doi.org/10.1007/s10750-006-0431-6

RICHTER, E.M.; FORNARO, A.; LAGO, C.L.; ANGNES, L. Avaliação da composição química de águas do Sistema Guarapiranga: estudo de caso nos anos de 2002 e 2003. Química Nova, São Paulo, v. 30, n. 5, p. 1147-1152, 2007. http://dx.doi.org/10.1590/S010040422007000500018

ROBERTS, M.J.; LONG, S.P.; TIESZEN, L.L.; BEADLE, C.L. Measurement of plant biomass and net primary production. In: COOMBS, J.; HALL, D.O.; LONG, S.P.; SCURLOCK, J.M.O. (Eds). Techniques in bioproductivity and photosynthesis. $2^{\mathrm{a}}$ ed, Oxford: Pergamon Press, 2014. p. 1-19.

ROUCO, M.; LÓPEZ-RODAS, V.; GONZALEZ, R. HUERTAS, I.E.; GARCÍA-SANCHÉZ, M.J.; FLORES-MOYA, A.; COSTAS, E. The limit of the genetic adaptation to copper in freshwater phytoplankton. Oecologia, Berlin, v. 175, n.4, p. 1179-1188. 2014. https://doi.org/10.1007/s00442-014-2963-1

SCHAFER, R. B.; BUNDSCHUH, M.; ROUCH, D. A.; SZOCS, E.; OHE, P. C.; PETTIGROVE, V.; SCHULZ, R.; NUGEGODA, D. KEFFORD, B. J. Effects of pesticide toxicity, salinity and other environmental variables on selected ecosystem functions in streams and the relevance for ecosystem services. Science of the Total Environment, v. 415, p. 6978 ,

2012. https://doi.org/10.1016/j.scitotenv.2011.05.063

SCHEIBENER, S.A.; RIVERA, N.A.; HESTERBERG, D.; DUCKWORTH, O.; BUCHWALTER, D.B. Periphyton uptake and trophic transfer of coal fly-ash-derived trace elements. Environmental Toxicology and Chemistry, Toronto, v. 36, n. 11, p. 2991-2996, 2017. https://doi.org/10.1002/etc.3864

SERRA, A.; CORCHOLL, N.; GUASH, H. Copper accumulation and toxicity in fluvial periphyton: the influence of exposure history. Chemosphere, v. 74, n. 5, p. 633-641, 2009. https://doi.org/10.1016/j.chemosphere.2008.10.036

SILVA, D.C.V.R. Toxicidade da água e sedimentos nos reservatórios Guarapiranga, Billings e Paiva Castro, em São Paulo. Dissertação (Mestrado em Ecologia) - Programa de Pós graduação em Ecologia - Universidade de São Paulo, São Paulo, 2013. 165 p.

SMUCKER, N. J.; DETENBECK, N. E.; MORRISON, A. C. Diatom responses to watershed development and potential moderating effects of near-stream forest and wetland cover. Freshwater Science, Chicago, v. 32, p. 230-249, 2013. https://doi.org/10.1899/11-171.1

SONG, L.Y.; WANG, Y.Q. Investigation of microbial community structure of a shallow lake after one season copper sulfate algaecide treatment. Microbiological Research, v. 170, n. 1, p. 105-113, 2015. https://doi.org/10.1016/j.micres.2014.08.008

SOUSA, M.L.; SILVA, S.C.; POMPÊO, M.L.M. Bioacumulação de cobre no biofilme perifítico e seu impacto ecológico. Ciência Tecnologia \& Ambiente, São Carlos, v. 6, n. 1, p. 301-306, 2017. 
SOUZA, M.L.; PELLEGRINI, B.G.; FERRAGUT, C. Periphytic algal community structure in relation to seasonal variation and macrophyte richness in a shallow tropical reservoir. Hydrobiologia, v. 755, n. 1, p. 183-196, 2015. https://doi.org/10.1007/s10750-015-2232-2

STEWART, T.J.; TRABER, J.; KROLL, A.; BEHRA, R.; SIGG, L. Characterization of extracellular polymeric substances (EPS) from periphyton using liquid chromatographyorganic carbon detection-organic nitrogen detection (LC-OCD-OND). Environmental Science and Pollution Research, v. 20, n. 5, p. 3214-3223, 2013. https://doi.org/10.1007/s11356-012-1228-y

TAKAMURA-ENYA, T.; TOKUTAKE, M. Novel speciation analysis of copper in river water: observation of soluble anionic copper-ligand complexes. Limnology, v. 17, n. 2, p. 117-125, 2016. https://doi.org/10.1007/s10201-015-0468-1

TANG, J.; NINGYUAN, Z.; YAN, Z.; JUNZHUO, L.; CHENXI, W.; KERR, P.; YONGHONG, W.; LAM, P.K.S. Responses of periphyton to Fe2O3 nanoparticles: A physiological and ecological basis for defending nanotoxicity. Environmental Science and $\begin{array}{llllll}\text { Technology, } & \text { v. } 51, \quad \text { n. } 18, & \text { p. } & 10797-10805, & 2017 .\end{array}$ https://doi.org/10.1021/acs.est.7b02012

TORGAN, L.C.; BERTOLLI, L.M.; TALGATTI, D.M.; SALMONI, S. Colonização e sucessão do perifíton. In: SCHWARZBOLD, A.; BURLIGA, A.L.; TORGAN, L.C. (Eds.) Ecologia do perifíton. São Carlos: Rima, 2013. p. 45-58

TORRES, P.B.; CHOW, F.; FURLAN, C.M.; MANDELlI, F.; MERCADANTE, A.; SANTOS, D.Y.A.C. Standardization of a protocol to extract and analyze chlorophyll a and carotenoids in Gracilaria tenuistipitata Var. Liui. Zhang and Xia (Rhodophyta). Brazilian Journal of Oceanography, São Paulo, v. 62, n. 1, p. 57-63, 2014. https://doi.org/10.1590/s1679-87592014068106201

WETZEL, R.G. Recommendations for future research on periphyton. In: WETZEL, R.G. (Ed.) Periphyton of freshwater ecosystems, $1^{\text {a }}$ ed. Dordrecht: Springer, 1983. p. 339-346.

WEYER, K.M.; BUSH, D.R.; DARZINS, A.; WILSON, B.D. Theoretical Maximum Algal Oil Production. Bioenergy Research, v. 3, n. 2, p. 204-213, 2010. https://doi.org/10.1007/s12155-009-9046-X

YONGHONG, W. Periphyton: functions and applications in environmental remediation. 1 ed., Amsterdam: Elsevier, 2016. 434 p.

YONGHONG, W.; LIZHONG, X.; ZHIQIANG, Y.; SHABBIR, S.; KERR, P.G. In situ bioremediation of surface waters by periphytons. Bioresource Technology, v. 151, n. 1, p. 367-372, 2014. https://doi.org/10.1016/j.biortech.2013.10.088 


\section{Supplementary Material}

Table I: Composition of LC Oligo medium (ABNT, 2018 - with adaptations) and amount of each stock solution necessary for preparing $1 \mathrm{~L}$ of LC Oligo medium

\begin{tabular}{|c|c|c|c|}
\hline $\begin{array}{l}\text { Stock } \\
\text { Solution }\end{array}$ & Compound & $\begin{array}{l}\text { Total in } 100 \mathrm{~mL} \\
\text { of deionized } \\
\text { water. }\end{array}$ & $\begin{array}{l}\text { Stock solution / L } \\
\text { of LC Oligo }\end{array}$ \\
\hline 1 & Calcium Nitrate tetrahydrate & $4000 \mathrm{mg}$ & $1 \mathrm{ml}$ \\
\hline 2 & Potassium nitrate & $10000 \mathrm{mg}$ & $1 \mathrm{ml}$ \\
\hline 3 & $\begin{array}{l}\text { Magnesium sulfate } \\
\text { heptahydrate }\end{array}$ & $3000 \mathrm{mg}$ & $1 \mathrm{ml}$ \\
\hline 4 & Dibasic potassium phosphate & $4000 \mathrm{mg}$ & $1 \mathrm{ml}$ \\
\hline \multirow[t]{7}{*}{5} & $\begin{array}{l}\text { Copper sulphate } \\
\text { pentahydrate }\end{array}$ & $3 \mathrm{mg}$ & $0,5 \mathrm{ml}$ \\
\hline & $\begin{array}{l}\text { Ammonium molybdate } \\
\text { tetrahydrate }\end{array}$ & $6 \mathrm{mg}$ & \\
\hline & Zinc Sulphate heptahydrate & $6 \mathrm{mg}$ & \\
\hline & Cobalt chloride hexahydrate & $6 \mathrm{mg}$ & \\
\hline & $\begin{array}{l}\text { Manganese nitrate } \\
\text { tetrahydrate }\end{array}$ & $6 \mathrm{mg}$ & \\
\hline & Citric acid monohydrate & $6 \mathrm{mg}$ & \\
\hline & Boric acid & $6 \mathrm{mg}$ & \\
\hline \multirow[t]{2}{*}{6} & Iron chloride hexahydrate & $62,5 \mathrm{mg}$ & $1 \mathrm{ml}$ \\
\hline & Iron sulphate heptahydrate & $62,5 \mathrm{mg}$ & \\
\hline 7 & Sodium bicarbonate & $1500 \mathrm{mg}$ & $1 \mathrm{ml}$ \\
\hline
\end{tabular}


Table II: Qualitative analysis of periphyton samples

\begin{tabular}{|c|c|c|c|c|c|}
\hline Species & Control & $0.013 \mathrm{mg}$ & $0.06 \mathrm{mg}$ & $0.1 \mathrm{mg}$ & $0.15 \mathrm{mg}$ \\
\hline Achantidium sp. & 2 & 4 & 4 & & 2 \\
\hline Amphipleura sp. & & & 1 & 2 & \\
\hline Amphora sp. & 1 & & & & \\
\hline Anabena sp. & & & & & 3 \\
\hline Ankistrodesmus faleatus & 8 & 10 & 16 & 16 & 14 \\
\hline Ankistrodesmus fusiformis & 2 & & 5 & & \\
\hline Aphanotece sp. & & & 9 & & 3 \\
\hline Bulbochaete sp. & & & & 1 & \\
\hline Chrococcus sp. & & & 3 & & 5 \\
\hline Cocconeis sp. & 1 & 2 & & 2 & \\
\hline Colesastrum proboescidium & 1 & 1 & 9 & 7 & 8 \\
\hline Cosmarium sp. & & 10 & 4 & 2 & 3 \\
\hline Cosmarium sp. 1 & & & 2 & & 1 \\
\hline Cymbella sp. & 1 & 1 & 2 & 1 & \\
\hline Desmodesmus aculeolatus & & & 40 & 21 & 23 \\
\hline Encyonema sp. & & & & 1 & 1 \\
\hline Euglena sp. & 1 & & 1 & 2 & \\
\hline Gonatozygon tenuissimum & 3 & 9 & 7 & 7 & 3 \\
\hline Leibleinia epiphitica & 9 & 6 & 5 & 3 & 6 \\
\hline Microchaete diplosiphon & 21 & 18 & 42 & 10 & 18 \\
\hline Microcystis aeruginosa & 3 & 2 & 5 & 1 & \\
\hline Microcystis wesenbergii & & 2 & 2 & & 3 \\
\hline Monoraphidium sp. & 6 & 4 & 7 & 10 & 2 \\
\hline Monoraphidium contortun & & 5 & & 4 & 2 \\
\hline Mougeotia sp. & 12 & 1 & 13 & & 4 \\
\hline Mougeotia sp 1 & & 1 & 5 & 2 & \\
\hline Navicula sp. & 2 & 4 & 15 & 18 & 8 \\
\hline Nitzschia sp. & 2 & & & & \\
\hline Neidium sp. & 2 & & & & \\
\hline Pediastrum boreanyum & 5 & 3 & 6 & 3 & 1 \\
\hline Pediastrum tetras & 2 & & 2 & 2 & 4 \\
\hline Pseudanabaena catenata & 5 & 4 & & & \\
\hline Pseudanabaena minima & 303 & 504 & 482 & 404 & 275 \\
\hline Phacotus sp. & & 6 & 11 & 3 & 1 \\
\hline Phormidium foreaui & 24 & 4 & 9 & 3 & 1 \\
\hline
\end{tabular}




\begin{tabular}{|c|c|c|c|c|c|}
\hline Placoneis sp. & & & & 1 & \\
\hline Planktolyngbya limnetica & 110 & 277 & 352 & 547 & 475 \\
\hline Planktothrix agardii & 1 & & & & \\
\hline Pteromonas sp. & & 16 & 19 & 1 & 1 \\
\hline Raphidonema sp. & 10 & 1 & & & \\
\hline Scenedesmus ecornis & 14 & 12 & 10 & 9 & 5 \\
\hline Scenedesmus obtusus & 1 & & 3 & 1 & \\
\hline Scenedesmus pectinatus & 2 & 4 & 9 & 5 & 5 \\
\hline Scenedesmus perforatus & 2 & & 2 & 2 & \\
\hline Scenedesmus quadricauda & 106 & 117 & 237 & 128 & 134 \\
\hline Scenedesmus sp & 4 & 2 & 7 & & 3 \\
\hline Spirogera sp. & 1 & & & & \\
\hline Suriella sp. & 1 & 2 & 1 & & \\
\hline Tetrastum sp. & & & 2 & & \\
\hline Uronema sp. & & & & 1 & 3 \\
\hline
\end{tabular}




\section{Capítulo 4}

\section{CAFFEINE AS A CONTAMINANT OF PERIPHYTON: ECOLOGICAL CHANGES AND IMPACTS ON PRIMARY PRODUCERS}

\section{Mariana Lopes de SOUSA ${ }^{1}$ *; Déborah Yara Alves Cursino dos $\operatorname{SANTOS}^{2}$; Fungyi $\mathrm{CHOW}^{3}$; Marcelo Luiz Martins POMPẾ ${ }^{1}$}

\footnotetext{
${ }^{1}$ Laboratory of Limnology, Department of Ecology, Institute of Bioscience, University of São Paulo.

${ }^{2}$ Laboratory of Phytochemistry, Department of Botany, Institute of Bioscience, University of São Paulo.

${ }^{3}$ Laboratory of Marine Algae "Édison José de Paula", Department of Botany, Institute of Bioscience, University of São Paulo.
}

*Manuscrito submetido ao periódico Journal of Applied Phycology 


\section{Resumo}

Diariamente, toneladas de cafeína são consumidas pelo ser humano em bebidas, suplementos e medicamentos. Consequentemente, uma grande parte deste composto estimulante é lançada nos corpos d'água na forma de esgoto doméstico. Uma vez no ecossistema, a cafeína interage diretamente com a comunidade perifítica, a qual é responsável por uma grande parte da produção primária em ecossistemas aquáticos. Entretanto, os efeitos da cafeína são em sua maioria desconhecidos para o perifíton e seus predadores diretos. Com o objetivo de compreender então esses efeitos causados pela interação da cafeína com o biofilme perifítico, foram realizados experimento ecotoxicológicos expondo o perifíton previamente cultivado em laboratório á diferentes concentrações de cafeína. Foram utilizadas concentrações previamente identificadas em esgoto doméstico. O impacto da contaminação foi observado na estrutura da comunidade perifítica, através de identificação taxonômica, assim como a análise de diversas variáveis fisiológicas ligadas á produção primária. Após a exposição á cafeína, a densidade do gênero Scenedesmus foi severamente afetada, levando á um aumento em proporção das cianobactérias e diatomáceas. Tanto a riqueza quanto a diversidade diminuíram após a contaminação, além de menor atividade fotossintética. $\mathrm{O}$ ponto de saturação luminosa mudou de $186 \mu \mathrm{mol} \mathrm{m} \mathrm{m}^{-2} \mathrm{~s}^{-1}$ no tratamento controle para $108 \mu \mathrm{mol} \mathrm{m}{ }^{-2}$ $\mathrm{s}^{-1}$ após a contaminação. Também foi observado acúmulo de cafeína não metabolizada no biofilme, durante as primeiras 24 horas de contaminação, na concentração de $0,14 \mu \mathrm{g} / \mathrm{cm}^{2}$.

Palavras-chave: Algas, Bioacumulação, Ecotoxicidade, Efluente, Qualidade da água. 


\begin{abstract}
Every day, tons of caffeine is consumed by humans in beverages, medications or supplements, and a significant amount of this stimulant is released in domestic sewage. Once in aquatic environments caffeine interacts directly with the periphytic community, which is responsible for a significant part of primary production in aquatic ecosystems. However, the effects of caffeine contamination are mostly unknown for both the periphyton and their predators. Aiming to comprehend the interaction between caffeine and the periphytic community, ecotoxicological experiments were performed by exposing a biofilm cultivated in the laboratory to different concentrations of caffeine, following concentrations found in domestic sewers. The impact of contamination was observed on the structure of the community through taxonomic evaluation, as well a set of physiological variables linked to primary production. After caffeine exposure, the density of the genus Scenedesmus was severely affected, leading to an increase in cyanobacteria and diatoms. Both richness and diversity decreased after contamination, and there was lower photosynthetic activity, with light saturation point changing from $186 \mu \mathrm{mol} \mathrm{m} \mathrm{s}^{-1}$ in the control treatment to $108 \mu \mathrm{mol} \mathrm{m}$ $\mathrm{s}^{-1}$ after contamination. Caffeine accumulation within the biofilm was also observed during the first $24 \mathrm{~h}$, in the concentration of $0.14 \mu \mathrm{g} / \mathrm{cm}^{2}$.
\end{abstract}

Keywords: Algae, Bioaccumulation, Ecotoxicity, Effluent, Water Quality, Microcosm. 


\section{Abbreviations}

AFDM: Ash Free Dry Mass

Chl-a: Chlorophyll-a

ETR: Electron transport rate

Ik: Light saturation point

PAR: Photosynthetically active radiation

PSII: Photosystem II 


\section{Introduction}

Humankind has been consuming caffeine for thousands of years. Since old Chinese dynasties, caffeine has been known as a stimulant and diuretic substance, consumed primarily in teas and infusions. In contrast, coffee (Coffea sp.) only started being consumed during the XIV century in the Middle East (FREDHOLM, 2011), and has spread globally since then. Since caffeine is an alkaloid found in several plant species (GRACIA-LOR et al., 2017), it is produced on a large scale, which justifies its wide consumption by society. Nowadays, $70 \%$ of the caffeine consumed worldwide comes from coffee (MONTAGNER et al., 2014). Other sources such as teas, medications, soft drinks, chocolates, and dietary supplements are also very common (GRACIA-LOR, et al. 2017). Since concerns about this compound are relatively recent, and its complete environmental consequences are unknown, caffeine is considered an emerging contaminant of aquatic ecosystems (AHMED et al., 2017), and indicator of anthropic activity (IDE et al., 2013).

Caffeine reaches water bodies due to domestic sewage and industrial wastewater contamination (GONÇALVES et al., 2017). Even though this compound is easily degraded in sewage treatment plants (BUERGE et al., 2003), many countries still struggle in providing basic sanitation programs. According to a recent report from Uhlenbrook et al. (2017), about $80 \%$ of the wastewater in the world is discharged in environment without treatment. This percentage in event higher in low-income countries, and can reach up to 95\%. This way, a large percentage of raw sewage reaches the environment daily, leading to a continuous contamination by caffeine (GONÇALVES et al., 2017). It has been estimated that up to 5\% of all the caffeine consumed is integrally released within domestic sewage (MONTAGNER et al., 2014), while the remaining is absorbed and metabolized in liver (GRACIA-LOR et al., 2017). The daily average ingestion rates vary between 84 to $240 \mathrm{mg} /$ day for average $(70 \mathrm{~kg}$ ) adults, depending on their country and age group (MONTAGNER et al., 2014). According to Sodré et al. (2010), the concentration of caffeine in raw sewage can reach up to $300 \mu \mathrm{g} / \mathrm{L}$, and can vary depending on the country or the habits of the population (BUERGE et al., 2003; MONTAGNER et al., 2014). This concentration is high enough to affect several aquatic organisms like fishes, amphibians, mollusks, and primary producers, the latter being phytoplankton or periphyton (DAFOUZ et al., 2018). 
Regarding periphyton, it is a community composed primarily of microalgae, fungi, bacteria and other small organisms, forming a biofilm attached to any substrate that plays a substantial role in aquatic food chains (WETZEL \& LIKENS, 1991). According to Lawrence et al. (2012) caffeine in concentrations higher than $5 \mu \mathrm{g} / \mathrm{L}$ directly affected the production of exopolymers and the growth of certain algae groups, leading to changes in periphyton composition. In cases where concentrations were higher than $2.91 \mathrm{~g} / \mathrm{L}$, caffeine effectively decreased the respiration of periphyton (ROSI-MARSHALL, et al. 2013). On the other hand, SHAW et al. (2015) showed that caffeine concentrations of $485 \mathrm{mg} / \mathrm{L}$ actually had a positive impact on primary production in experiments with microcosms. Such conflicting results indicate that periphyton is a complex community, since it is composed of diverse taxonomic groups. Thus, the results depend on the community composition and the interaction between these components (HOMMEN et al., 2016).

This work is based on the premise that caffeine affects the periphytic community, both ecologically and physiologically. Such fact would harm the periphyton, unbalancing the ecosystem. To verify these effects, ecotoxicological tests were performed to expose periphyton to different caffeine concentrations found in raw sewage. After 15 days, ecological and physiological effects were measured to determine the capacity of periphyton to degrade or accumulate caffeine.

\section{Methodology}

\section{Periphyton obtention and cultivation}

The initial periphyton inoculum was obtained from a lake located at the Institute of Biosciences at the University of São Paulo - Brazil (2333'55"S 46²43'51"W), which is free from outside contamination. Artificial circular substrates measuring $75 \mathrm{~mm}$ x $26 \mathrm{~mm}$ each, made of PolyEthylene Terephthalate (PET) were used for periphyton inoculum growth. The colonization period was of 21 days (TORGAN et al., 2013), and after that the substrates were removed from the lake and the periphytic inoculum collected. For that purpose, it was used a soft brush and deionized water. The resulting material was then transferred to a $50 \mathrm{~L}$ aquarium containing the glass slides vertically fixed $(2.6 \times 7.5 \mathrm{~cm})$, as substrate for cultivation and culture medium LC Oligo (ASSOCIAÇÃO BRASILEIRA DE NORMAS TÉCNICAS, 
2018).

For periphyton cultivation, the aquarium was kept under controlled conditions of light, temperature and oxygenation. Illumination was provided using $16 \mathrm{~W}$ fluorescent lamps (photoperiods of $12 \mathrm{~h}$ ), aeration was provided using two $3 \mathrm{~W}$ air pumps (model s2000, Boyu) and air curtain bubble diffusers. The temperature was maintained at $24{ }^{\circ} \mathrm{C}$ using a $100 \mathrm{~W}$ heater and thermostat (model At-100, Atmam). The culture medium and water lost by evaporation were replaced on a weekly basis, and the $\mathrm{pH}$ was adjusted to $\mathrm{pH} \sim 7.0$. After of 21 days of cultivation (SOUSA et al., 2019) it was observed a well-developed layer of periphyton attached to each glass slide. Once the slides were cultivated under the same conditions, they had the same amount of biofilm, with the same community composition, assuring the replicability of the experiments.

\section{Ecotoxicity test - Experimental design}

Two different experiments were performed in this work: Experiment $\mathrm{A}$ - which observed the effects of different caffeine concentrations on periphyton, and Experiment B which observed the effects of periphyton on caffeine degradation over time, and bioaccumulation on biofilm.

In Experiment A, were used the concentrations of $0 \mu \mathrm{g} \mathrm{L}^{-1}$ (control), $20 \mu \mathrm{g} \mathrm{L}^{-1}, 75 \mu \mathrm{g} \mathrm{L}^{-}$ $1,150 \mu \mathrm{g} \mathrm{L}^{-1}$ and $300 \mu \mathrm{g} \mathrm{L}^{-1}$, according to the raw sewage values from different countries reported by Buerge et al. (2003) and Sodré et al. (2010). The experiment was performed by exposing groups of seven slides of cultivated periphyton to a $1.5 \mathrm{~L}$ microcosm containing the LC Oligo medium and the caffeine (SOUSA et al., 2019). Each treatment was performed in triplicate, totalizing 15 microcosms in Experiment A. Experiment lasted 15 days, and during this time the vessels were kept in an incubator chamber (model 411FPD, Ethik), under the same lab conditions of illumination, $\mathrm{pH}$ and temperature employed for the aquarium culture. After this period, the microcosms were removed for analysis.

In Experiment B, the test was performed again by exposing groups of seven slides of cultivated periphyton to a $1.5 \mathrm{~L}$ microcosm containing the LC Oligo medium and caffeine (5 $\mathrm{mg} \mathrm{L}^{-1}$ ). For this treatment were used 10 microcosms, a triplicate for control without caffeine, and a triplicate for control containing caffeine but without periphyton, totalizing 16 microcosms. Exposition period was 10 days, during this period one microcosm was taken daily for analysis. Samples of the controls were taken daily also. 


\section{Taxonomic characterization and ecological parameters}

Characterization of the periphyton community was studied only in Experiment A. Periphyton from one glass slide of each microcosm was collected using a soft brush and deionized water, preserved in 10\% Lugol's iodine as described by Yonghong (2016). In this analysis, the samples of each triplicate were combined, resulting in one sample for each treatment, i.e. there was no replication of samples $(n=1)$. The algal composition of periphyton was identified at species level, using several identification guides: Bicudo and Menezes (2006), Franceschini (2013), Ludwig and Tremarin (2013), and Lamparelli et al. (2014). Quantitative procedures employed rarefaction curves (BICUDO, 1990), using at least 100 individuals of the most abundant species. Species richness, density, Shannon's diversity, distribution of different algae groups and descriptive species at $2 \%$ of total density (FELISBERTO \& RODRIGUES, 2012) were calculated for each concentration.

\section{Chlorophyll-a and ash-free dry mass}

Ash-free dry mass (AFDM) was determined based on Roberts et al. (2014). In Experiment $\mathrm{A}$ it was determined at the end of exposition period, in triplicate for each treatment. In Experiment B it was determined for samples in day 0 and day 10, also in triplicate for each treatment (control and $5 \mathrm{mg} \mathrm{L}^{-1}$ of caffeine). Biofilm of one glass slide was collected and filtered using glass fiber filters (AP40, Millipore) and dried in an oven at $65{ }^{\circ} \mathrm{C}$ until the weight stabilized. After obtaining the dry weight, the material was combusted in a muffle furnace $\left(450{ }^{\circ} \mathrm{C}, 60 \mathrm{~min}\right)$ in order to obtain the ashes. The AFDM was obtained by subtracting the weight of the ash from the dry weight.

Chlorophyll- $a$ (Chl- $a$ ) was determined only in Experiment A, at the end of exposure period, in triplicate for each treatment. The same way as AFDM, biofilm of one glass slide was collected and filtered using glass fiber filters (AP40, Millipore). The Chl- $a$ was extracted and quantified according to the methodology described by Torres et al. (2014). The filtered biofilm was macerated and extracted into $90 \%$ acetone, followed by centrifugation at 3000 rpm for $15 \mathrm{~min}$. The absorbance of the supernatant was measured using a spectrophotometer (model B572, Micronal). 


\section{Electron transportation rate and Light saturation curve}

These parameters were measured in Experiment A only, at the end of exposure period, in triplicate for each treatment. Material was used in vivo to evaluate the physiological functioning of the community regarding photosynthesis (KUMAR et al., 2014).

Using a pulse amplitude modulation fluorometer (model PAM-2500, Waltz), relative electron transport rate (rETR) was assessed after periphyton exposure to consecutive luminous pulses at different intensities within the photosynthetically active radiation (PAR) range (WEYER et al., 2010). The wavelength range varied between 0 to $750 \mu \mathrm{mol} \mathrm{m}-2 \mathrm{~s}-1$ (KUMAR et al., 2017). Using this data, light saturation curves were also built in order to find the light saturation point (Ik) for each treatment.

Caffeine accumulation and degradation

The degradation of caffeine and its bioaccumulative potential were studied in Experiment B. Three parameters were observed: caffeine in water (deionized and without periphyton or any organism); caffeine in water that was in contact with periphyton; and caffeine in the periphytic biofilm itself, after exposure. Samples of water $(50 \mathrm{ml})$ were collected using sterilized glass pipettes, and periphyton samples were collected using a soft brush and deionized water. Samples were collected daily (during 10 days), and immediately processed. Samples were collected in triplicate for both water and periphyton.

Caffeine was extracted from the samples using dichloromethane (TORRES et al., 2015), filtration using glass fiber filters (AP40, Millipore) followed by drying and resuspension in methanol. Samples were then read using a gas chromatograph attached to a mass spectrometer (Agilent 6850/5975) with a $30 \mathrm{~m}$ x $0.25 \mathrm{~mm}$ column (HP-5MS). The injector operated at a constant temperature of $250{ }^{\circ} \mathrm{C}$. Analyses were temperature programmed from $150{ }^{\circ} \mathrm{C}(5 \mathrm{~min}$ hold $)$ to $190{ }^{\circ} \mathrm{C}$, at $10^{\circ} \mathrm{C} / \mathrm{min}$ for $5 \mathrm{~min}$, after increasing at $20{ }^{\circ} \mathrm{C} / \mathrm{min}$ to $310^{\circ} \mathrm{C}$. Helium was used as a carrier gas at a constant flow of $1.0 \mathrm{~mL} / \mathrm{min}$. EM voltage used was $70 \mathrm{~V}$, interface temperature was $280^{\circ} \mathrm{C}$ and quadrupole temperature was $180{ }^{\circ} \mathrm{C}$. Volume of the sample injected was $1 \mu \mathrm{L}$, using splitless injection technique and was analyzed in scan mode $(40 \quad-\quad 600 \quad$ u.m.a., 2.64 scan/s $)$. 


\section{Data analysis}

Significant alterations between the treatments for AFDM and Chl-a in Experiment A were verified through one-way ANOVA followed by Tukey's test - $\mathrm{p}<0.05$ (POTVIN, 2001) using OriginPro 8.5 (OriginLab). For Experiment B, AFDM was analyzed using two-way ANOVA. The assumptions of normality and homoskedasticity were tested using Bartlett's test and Kolgomorov Smirnov's test, respectively.

All the artwork was also created using OriginPro 8.5 (OriginLab).

A principal component analysis (PCA) of the taxonomic data in Experiment A was performed by using Past software (Hammer et al. 2001). This multivariate analysis brings out strong patterns in the dataset, correlating the parameters of the biofilm with the different treatments $\left(0 \mu \mathrm{g} \mathrm{L}^{-1}, 20 \mu \mathrm{g} \mathrm{L}^{-1}, 75 \mu \mathrm{g} \mathrm{L}^{-1}, 150 \mu \mathrm{g} \mathrm{L}^{-1}\right.$ and $\left.300 \mu \mathrm{g} \mathrm{L}^{-1}\right)$. The main hypothesis of this analysis was to confirm that the effects of caffeine contamination can be identified through differentiation in periphyton composition. The data of algal groups, descriptive species, diversity, species richness, dominance, density were transformed using Cox-Box transformations. Then, data was submitted by normality tests (Jarque-Bera, Saphiro Wilk and Anderson Darling) in order to check if they were suitable to PCA analysis. The results were displayed in a biplot.

\section{Results}

Taxonomic characterization and ecological parameters

A total of 61 species were identified in the 5 treatments of Experiment A. Considering absolute values, both species richness $(\mathrm{N})$ and diversity according to Simpson's Index did not show a large range of variation between treatments, as observed in Table 1: 
Table 1: Richness (N), diversity and dominance in treatments of Experiment A

\begin{tabular}{lccc}
\hline Sample & N (species) & $\begin{array}{c}\text { Shannon's index } \\
\text { (diversity) }\end{array}$ & $\begin{array}{c}\text { Simpson's index } \\
\text { (dominance) }\end{array}$ \\
\hline Control & 30 & 2.39 & 0.14 \\
$20 \mu \mathrm{g}$ & 32 & 2.37 & 0.13 \\
$75 \mu \mathrm{g}$ & 27 & 2.34 & 0.15 \\
$150 \mu \mathrm{g}$ & 29 & 2.33 & 0.14 \\
$300 \mu \mathrm{g}$ & 24 & 2.02 & 0.21 \\
\hline
\end{tabular}

Regarding density and algal groups (Figure 1-a), density values increased until the 75 $\mu \mathrm{g} / \mathrm{L}$ caffeine treatment, then decreased with the lowest value at $300 \mu \mathrm{g} / \mathrm{L}$ treatment. The most abundant algal group from control to $150 \mu \mathrm{g}$ was Chlorophyceae, followed closely by Cyanophyceae. However, a different pattern was observed in the $300 \mu \mathrm{g} / \mathrm{L}$ treatment. The most abundant group was Cyanophyceae, followed by Bacillariophyta.

When applying the $2 \%$ total density criteria, 13 species were considered descriptive from the communities. Most of these species (8) belonged to Chlorophyceae, and particularly to genus Scenedesmus (Figure 1-b). Both control and $75 \mu \mathrm{g} / \mathrm{L}$ treatments had nine descriptive species. The $300 \mu \mathrm{g} / \mathrm{L}$ treatment had the least amount of descriptive species (7).

The most abundant species from control to $150 \mu \mathrm{g} / \mathrm{L}$ treatments was Planktolyngbya limnetica, accounting for between 20 to $27 \%$ of the total individuals. In the $300 \mu \mathrm{g} / \mathrm{L}$ (final) treatment, the most abundant species was Pseudanabaena minima, accounting for $30 \%$ of the total individuals, followed closely by Navicula sp., with $29 \%$. 
Figure: 1 (a) Density of each class in treatments of Experiment A; (b) Density of descriptive species in treatments of Experiment A

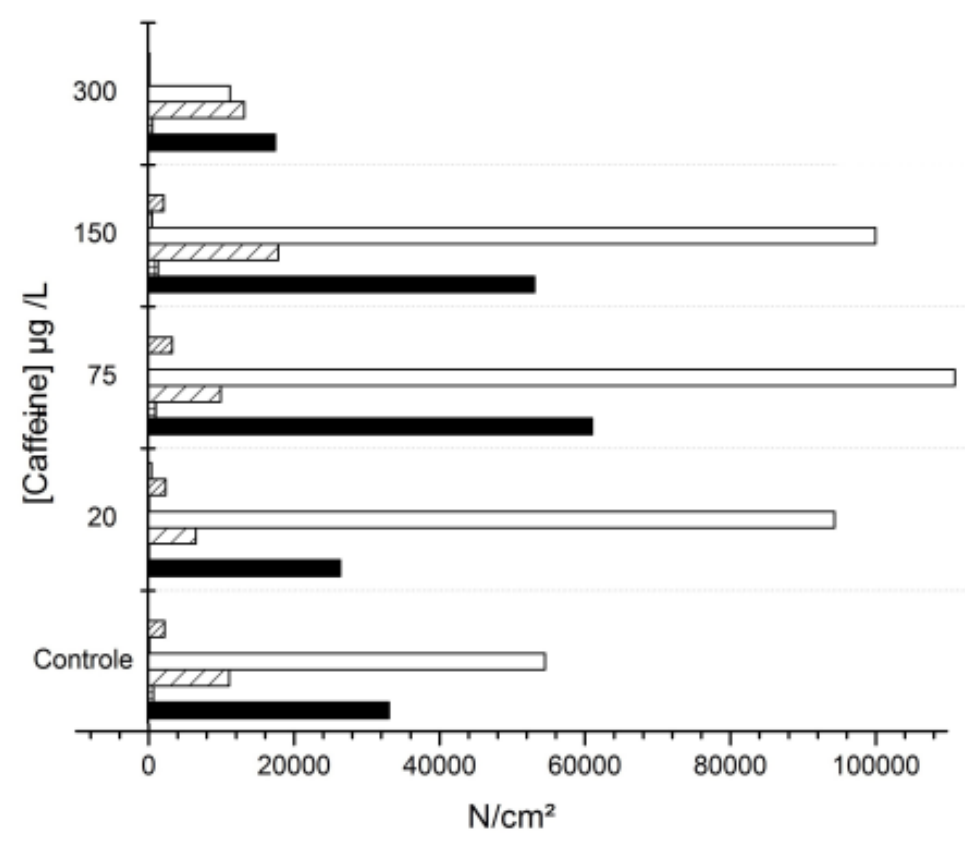

(a)

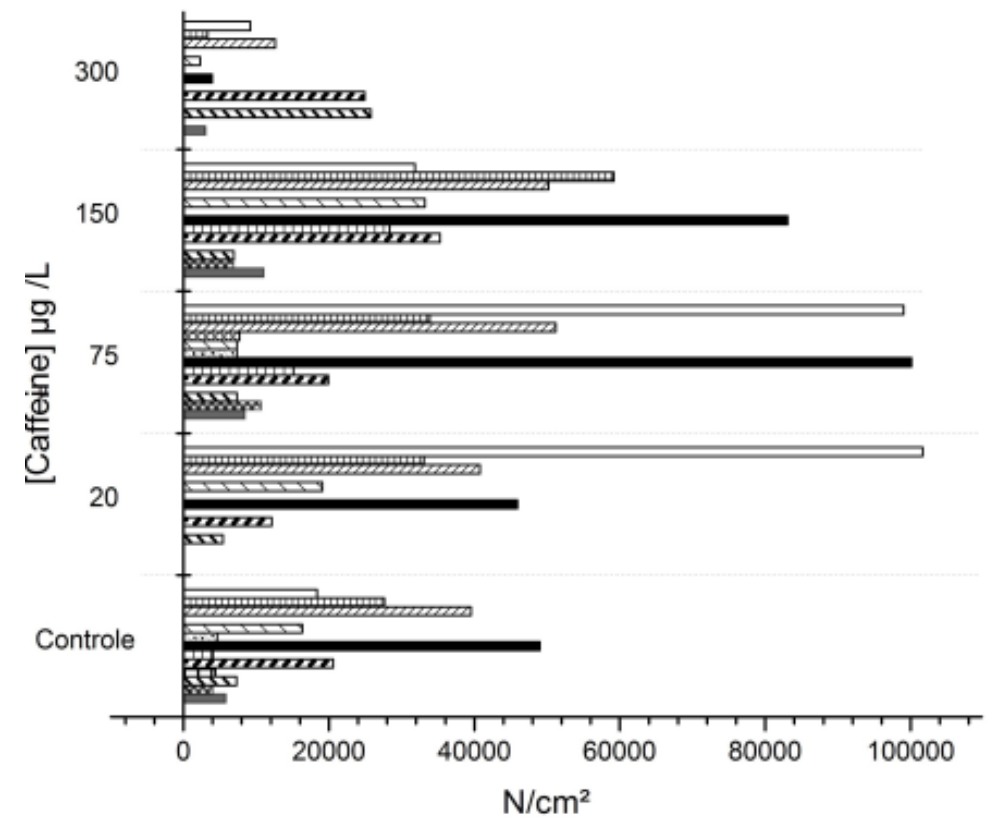

(b)

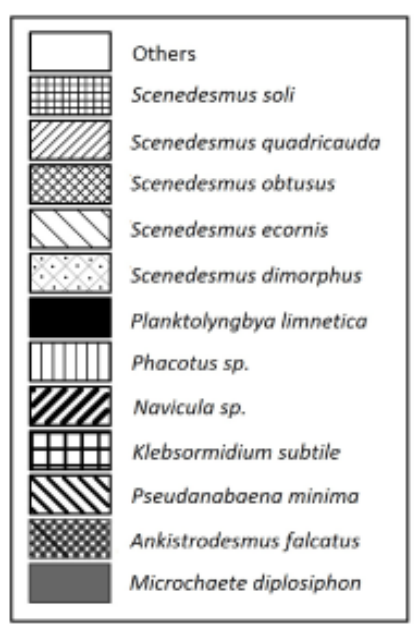


AFDM and Chl-a

According to the ANOVA results, there were no significant differences in the AFDM considering the different treatments in Experiment A. Additionally, Chl-a concentration in Experiment A was not different between the treatments after 15 days of caffeine exposure (Figure 2-a).

However, changes were observed when considering the weight variation over time, after caffeine contamination in Experiment B. In the absence of caffeine, the periphytic biofilm showed a significant increase in weight after $120 \mathrm{~h}$ when compared to the control ( $\mathrm{p}<$ 0.05). However, when exposed to caffeine $(5 \mathrm{mg} / \mathrm{L})$, there were no differences from the control after the same amount of time (Figure 2-b).

\section{ETR and photosynthetic curve}

Photosynthetic curves in Experiment A indicated that caffeine contamination caused different light saturation points (Ik) between treatments, as seen in Figure 2-c. In the control treatment, Ik occurred at $186 \mu \mathrm{mol} \mathrm{m} \mathrm{m}^{-2} \mathrm{~s}^{-1}$, followed by photoinhibition. However, after caffeine contamination, Ik occurred at $108 \mu \mathrm{mol} \mathrm{m} \mathrm{m}^{-2} \mathrm{~s}^{-1}$, even at the lowest concentration. Similarly, ETR presented higher values in the control treatment, decreasing with the gradient of caffeine contamination. The lowest Ik value was found in the $300 \mu \mathrm{g} / \mathrm{L}$ treatment. 
Figure 2: (a) AFDM and Chl-a in each treatment of Experiment A, after 15 days of caffeine exposure; (b) AFDM of periphyton after $120 \mathrm{~h}$ of caffeine exposure in Experiment B; (c) Photosynthetic curve and light saturation point of each treatment in Experiment A; and (d) Caffeine concentration throughout time according to each treatment in Experiment B

(a)
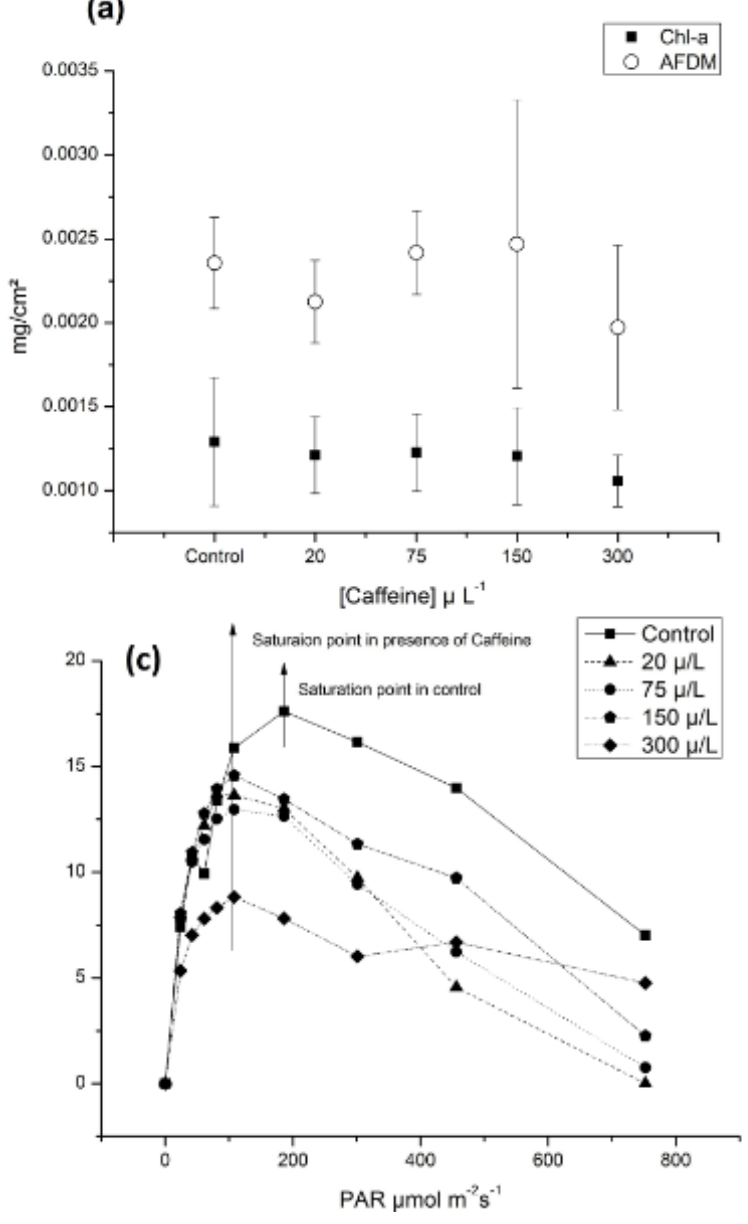

(b)
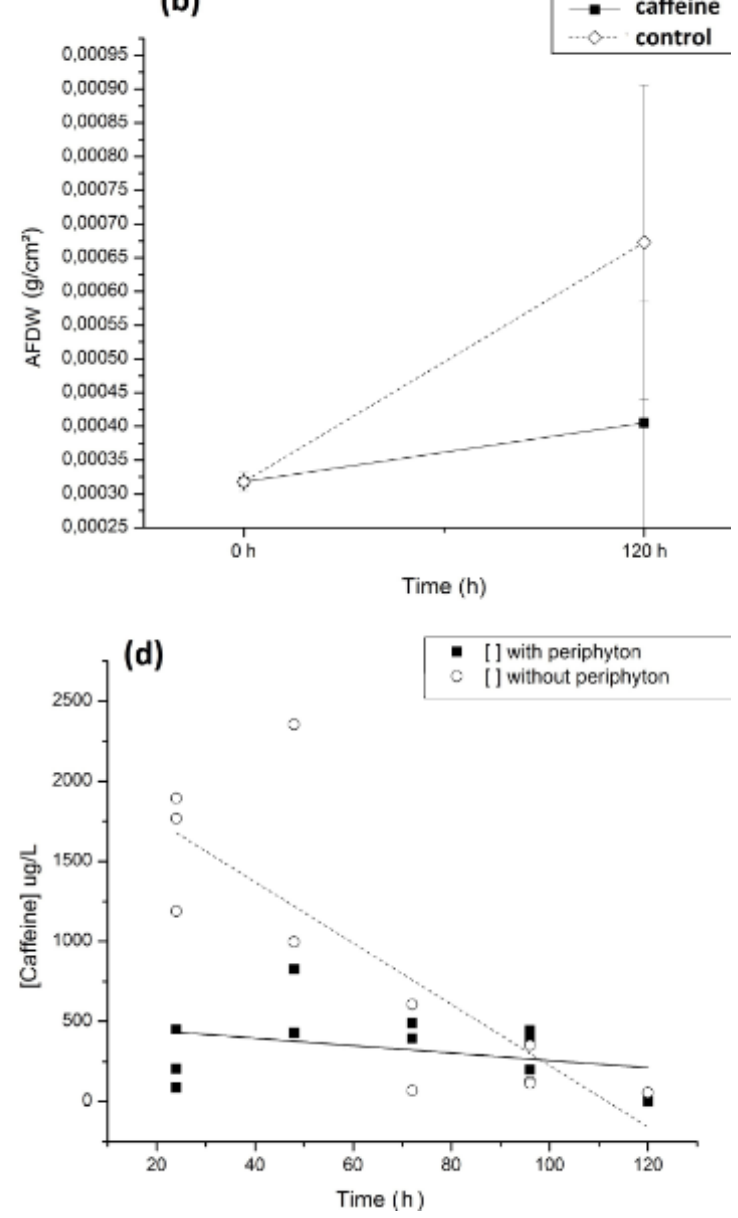

Principal Component Analysis

The PCA was performed with data from Experiment A, considering the taxonomic parameters only: density of different algal groups, total density, species richness diversity, and dominance (Figure 3). The first component (PC1) corresponded to $62.75 \%$ of data variation, while the second component (PC2) corresponded to 30.13\%. The $300 \mu \mathrm{g} / \mathrm{L}$ treatment was the most impacted, and was separated from the others, mainly related to dominance and diatom 
abundance (Figure 3). Intermediate concentrations were related to Cyanophyceae mostly. The control was related to diversity and species richness and Chlorophyceae density.

Figure 3: Biplot PCA loadings of eight ecological variables and scores of the treatments on the plane defined by component 1 (62.75\%) and 2 (30.13\%). Bac (Diatoms $\left./ \mathrm{cm}^{2}\right), \mathrm{Chl}\left(\right.$ Chlorophyceae $\left./ \mathrm{cm}^{2}\right)$, Cya $\left(\right.$ Cyanophyceae $\left./ \mathrm{cm}^{2}\right), \mathrm{D}$ (total density), H' (Diversity), Dom (Dominance), S (Species richness), Zyg (Zygnemaphyceae/cm2).

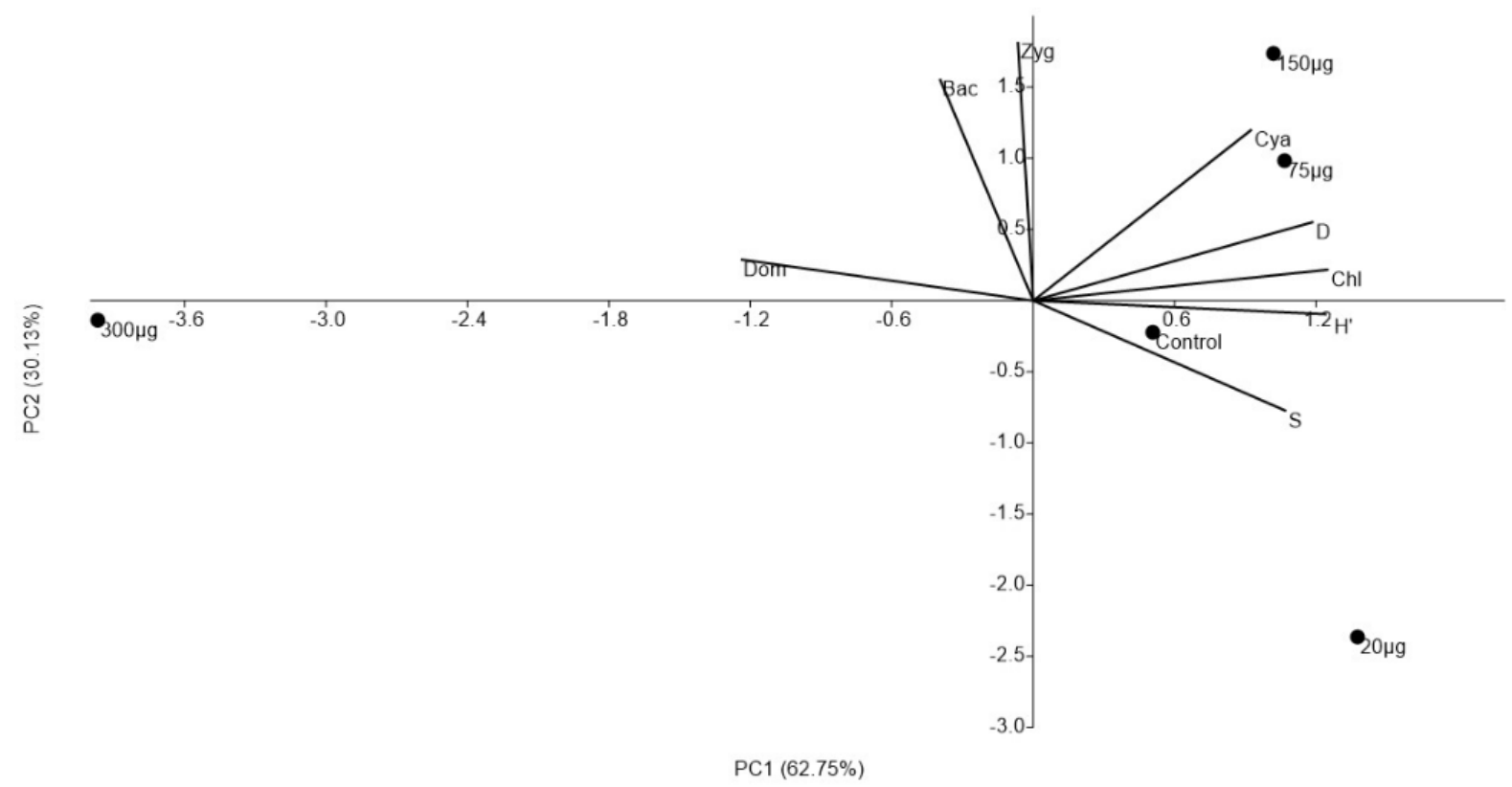

Caffeine degradation and accumulation

Caffeine in water was quickly degraded in all treatments of Experiment B, disappearing completely after $120 \mathrm{~h}$ of exposure, according to the GC/MS analysis. In the control treatment - without the presence of periphyton or any organism - a degradation rate of $60 \%$ in the first $24 \mathrm{~h}$ of exposure was observed. When caffeine was in contact with periphyton, degradation rate was of $90 \%$ in the same 24 h, as observed in Figure 2-d.

At the same time, non-metabolized caffeine was present accumulated in the biofilm 
during the first $24 \mathrm{~h}$ of the experiment, on the concentration of $0.14 \mu \mathrm{g}$ of caffeine $/ \mathrm{cm}^{2}$. Afterwards, all caffeine in the periphyton was degraded.

\section{Discussion}

Several ecological changes were observed after caffeine contamination. At concentrations up to $150 \mu \mathrm{g} / \mathrm{L}$, there was a noticeable increase in the total density (Figure 1a). Since Experiment B confirmed that caffeine was quickly degraded in the presence of periphyton (Figure 2-d), it is possible that the caffeine was used as a nutrient source for the biofilm (GRACIA-LOR et al., 2017). Scenedesmus was especially present among the descriptive species with higher density after caffeine exposure,. Such algae are particularly important in aquatic food chains due to their high palatability (BODINI et al., 2018). The density of Cyanophyceae also increased in these same treatments, as was expected for a developed biofilm, according to Dunck et al. (2015). Planktolyngbya limnetica, the most abundant species in the control, was even more present after caffeine exposure, reaching up to $27 \%$ of the total density in the $75 \mu \mathrm{g} / \mathrm{L}$ treatment.

However, in the $300 \mu \mathrm{g} / \mathrm{L}$ treatment (Figure 1-a), the periphytic community presented lower diversity if compared to other treatments, followed by lower richness and density (Table 1, Figure 1). The most affected group was Chlorophyceae, which decreased considerably and provided space for a higher abundance of diatoms (mainly Navicula sp.) and Cyanophyceae. This structural change could be highly problematic for periphyton consumers in environment, such as herbivore fishes, chironomidae, caddisflies, mayflies, amphibians and snails (CATTANEO \& MOUSSEAU, 1995; LIESS \& HILLEBRAND, 2004). Since Chlorophyceae is a highly palatable group (BURLIGA, 2010), the decrease in density affects directly dependent predators. This situation primarily can benefits generalist consumers such as snails and amphibians (STOLER \& RELYEA, 2015), since they can cope with the replacement of Chlorophyceae without significant difficulties (JOHNSTON et al., 2016). When observing the PCA of Experiment A (Figure 3), the division created by the caffeine gradient is evident In control there was close relation to richness, Chlorophyceae abundance and diversity. After caffeine contamination in $20 \mu \mathrm{g} / \mathrm{L}$ its relation to the same factors was much less intense. The 75 and $150 \mu \mathrm{g} / \mathrm{L}$ treatments were most correlated with total density 
and Cyanophyceae. Finally, due to its high correlation with dominance, low density and considerable loss of Chlorophyceae abundance, the $300 \mu \mathrm{g} / \mathrm{L}$ treatment was separated from the others on the biplot, and was considered the most impacted.

Although the taxonomic analysis showed several changes, they were not visible in the AFDM and Chl-a quantification. In Experiment A, there were no significant differences among the treatments, for both variables, even with the changes of density and dominance described above. When compared to the control, there was only a significant decrease in biofilm growth in Experiment B, when observing the effects of $5 \mathrm{mg} / \mathrm{L}$ caffeine after 10 days of exposure (Figure 2-b). This supports that higher concentrations of caffeine were not well accepted by the organisms in the periphyton, leading to a negative impact in primary production, as observed by Rosi-Marshall et al. (2013).

When observing the photosynthetic metabolism in Experiment A through light saturation point (Ik) and ETR, it is clear that caffeine affected the photosynthetic capacity in all treatments (Figure 2-c). Light saturation point in the presence of caffeine was reached faster at $108 \mu \mathrm{mol} \mathrm{m} \mathrm{m}^{-2} \mathrm{~s}^{-1}$, when compared to the control at $186 \mu \mathrm{mol} \mathrm{m}^{-2} \mathrm{~s}^{-1}$. Furthermore, the shapes of the photosynthetic curves (wavelength) after contamination were noticeably narrower. This implies that, light was being underused in photosynthesis by the community, indicating sensitivity to caffeine, and a decrease in primary production (LEI et al., 2015). Additionally, the decrease in ETR may be a direct ecological effect of caffeine. Since AFDM and Chl-a are related to the ETR results, which were not significantly different in Experiment A, the lower ETR found after contamination can be explained by the above mentioned changes in community composition. The higher abundance of Cyanophyceae and/or diatoms in caffeine treatments can decrease the ETR values, since their photosynthetic behavior is different from Chlorophyceae (HILL, 1996).

So far, the observed impacts of caffeine contamination were directly linked to the periphytic community. However, since the biofilm is consumed by several aquatic species, those negative effects or structural changes could impact higher trophic levels as well (YONGHONG, 2016).

Authors such as Jacobs et al. (2012), pointed out that caffeine is easily degraded in aquatic environments and in the presence of light, and this process is intensified in the presence of organic matter and organisms. However, once periphytic mucilage is capable of 
retaining various types of substances, nutrients, or contaminants (FELISBERTO \& MURAKAMI, 2013), any excess of caffeine would be removed from water and retained within the biofilm, being adsorbed. Then, caffeine would be bioavailable for the small organisms present in the periphyton (GRACIA-LOR et al., 2017), and incorporated as a nitrogen source. Nevertheless, if not metabolized the caffeine trapped in mucilage could be consumed by periphyton predators, causing damages in sensitive species. And Experiment B as shown in Figure 2-d, confirmed the existence of this process.

It was observed that caffeine was really easily degraded in water, and when in presence of periphyton, concentration observed even lower in first $24 \mathrm{~h}$. After GC/MS analysis, it was shown that caffeine was actually absorbed within the biofilm, but not yet metabolized. Concentration found was of $0.14 \mu \mathrm{g} / \mathrm{cm}^{2}$, or $0.7 \mathrm{nmol} / \mathrm{cm}^{2}$ of periphyton. This process explains the variations observed in Figure 2-d. Afterwards, in exposure periods higher than $24 \mathrm{~h}$, all the caffeine within the biofilm was naturally degraded/metabolized, not being observed in GC/MS. .

In order to understand the potential effects of this concentration on the consumers of periphyton, $1 \mathrm{~cm}^{2}$ corresponded to $0.5 \mathrm{mg}$ of dry mass in this experiment. Since fishes, snails, crustaceans, amphibians and several arthropods larvae are consumers of periphyton (LIESS \& HILLEBRAND 2004, CATTANEO \& MOUSSEAU, 1995), the accumulation of caffeine within the biofilm would primarily affect these groups.

For example, Aguirre-Martinez et al. (2017) concluded that caffeine causes oxidative stress in small fishes starting at $200 \mu \mathrm{mol}$, with $\mathrm{LC}_{50}$ for larvae at 3,480 $\mu \mathrm{mol}$. If applied to the results found on this study, this would mean that fish would need to ingest about $142 \mathrm{~g}$ of periphytic biofilm (in dry weight), cultivated in the same experimental conditions, to cause damage. Such amount is impractical, especially considering that the fishes that actually feed on periphyton, such as Gobio gobio and Chironomidae larvae (MAHDY et al., 2017), weigh about 2 g (WINKELMAN et al., 2014; ZENCIR \& KOFMARZ, 2016). Damages are even more unlikely when considering the caffeine concentration used in Experiment B is above that found in raw sewage.

However, snails are much more sensitive in relation to caffeine contamination. Ferreira et al. (2009) found that the $\mathrm{LC}_{50}$ of caffeine for this group, considering young individuals, is $5 \mathrm{~g} / \mathrm{L}$, but Silant'eva et al. (2009) pointed out that chronic exposure beginning 
at $30 \mathrm{mg} / \mathrm{kg}$ can cause behavioral and neurological damages in gastropods. Using as example Physa acuta, an important generalist periphyton predator (GARDHAN et al., 2015), caffeine contamination through periphyton consumption seems more likely to happen. According to the descripted in SAHA, et al. (2017), this species weighs an average of $24 \mathrm{mg}$. Therefore, it would be necessary $2.6 \mathrm{mg}$ of periphyton (in dry mass) cultivated in the same conditions as Experiment B to cause physiological damages.

Even though these correlations seems to indicate the potential of caffeine contamination through periphyton consumption, there is still a lack of field and experimental data regarding this process (DU et al.; 2015). This is explained in part once in environment many different factors can affect caffeine accumulation and toxicity, such as: continuous sewage disposal, distance from disposal point, effluent concentration and cascade effects with multiple contaminants (MONTAGNER et al., 2014). As a result, even if there is a small chance of caffeine contamination thorough periphyton ingestion, as seen in the extrapolations above, such possibility cannot be discarded, especially for sensitive groups as snails.

\section{Conclusions}

Caffeine is a common contaminant found in aquatic environments, with increasing representativeness in ecotoxicological studies. In this study, the periphytic biofilm was exposed to caffeine in laboratory and several alterations in its structure and physiology were noticed. Contamination lead to a loss of Chlorophyceae algae, especially for Scenedesmus sp., which were replaced by less palatable Cyanophyceae and diatoms. Caffeine also modified the photosynthetic behavior of the periphyton, with faster photoinhibition and a decrease in ETR values. Experiment B also showed accumulation of caffeine within the biofilm in the first 24 $\mathrm{h}$ of experiment. Such fact could lead to the contamination of higher trophic levels, caused by ingestion of contaminated periphyton, specially by highly sensitive groups such as snails. Therefore, even though caffeine is not a highly toxic compound, there are considerable effects caused by its contamination, as observed in its sublethal effects on periphyton. However, the scale of those effects varies significantly according to the concentration of caffeine released in aquatic environments. 


\section{Acknowledgements}

This work was supported by Coordenação de Aperfeiçoamento de Pessoal de Nível Superior Brasil (CAPES) - Finance Code 001 and Fundação de Amparo á Pesquisa do Estado de São

Paulo (FAPESP) - research grant (2014/22581-8). Fungyi Chow thanks Conselho Nacional de Desenvolvimento Científico e Tecnológico $(\mathrm{CNPq})$ for the productivity fellowship (303937/2015-7).

\section{References}

ASSOCIAÇÃO BRASILEIRA DE NORMAS TÉCNICAS. Ecotoxicologia aquática toxicidade crônica - método de ensaio com algas (Chlorophyceae) - Normativa NBR 12648:2018. Brasília, 2019. Disponível em: http://www.abntcatalogo.com.br/norma.aspx?ID=391089. Acessado em 1.3.2019.

AHMED, I.; IQBAL, H.M.N.; DHAMA, K. Enzyme-based biodegradation of hazardous pollutants - an overview. Journal of Experimental Biology and Agricultural Sciences, Salbord, v. 5, n. 4, p. 402-411, 2017. https://doi.org/10.18006/2017.5(4).402.411

AGUIRRE-MARTÍNEZ, G.V.; REINARDY, H.C.; MARTÍN-DÍAZ, M.L.; HENRY, T.B. Response of gene expression in zebrafish exposed to pharmaceutical mixtures: Implications for environmental risk. Ecotoxicology and Environmental Safety, v. 142, n. 1, p. 471-479, 2017.

https://doi.org/10.1016/j.ecoenv.2017.04.038

BICUDO, C.E.M. Metodologia para o estudo qualitativo do perifíton. Acta Limnologica Brasilica, v. 3, n. 1, p. 447-491, 1990.

BICUDO, C.E.M.; MENEZES, M. Gêneros de algas continentais no Brasil: guia para identificação e descrições. 1. ed. São Carlos: Rima, 2006. 522 p.

BODINI, A.; BANDAVALLI, C.; ROSSETI, G. Ecological sucession investigated through food-web flow network. In: MOORE, J.C.; RUITER, P.C.; MCCANN, K.S.; WOLTERS, V. (Eds) Adaptive Food Webs - Stability and transitions on real model ecosystems, $1^{\mathrm{a}}$ ed. Cambridge: Cambridge University Press, 2018. p. 164-177.

BUERGE, I.J.; POIGER, T.; MULLER, M.D.; BUSER, H.R. Caffeine: An antropoghenic marker for wastewater contamination in surface waters. Environmental Science and Technology, v. 37, n. 4, p. 691-700, 2003. https://doi.org/doi/10.1021/es020125z 
BURLIGA, A.L. Abordagem de grupos funcionais em estudos do perifíton e fitoplâncton. In: FRANCESCHINI, I.M.; BURLIGA, A.L.; REVIERS, B.; PRADO, J.F.; RÉZIG, S.H. (Eds.) Algas: uma abordagem filogenética, taxonômica e ecológica, $2^{\mathrm{a}}$ ed., São Paulo: Artmed, 2010. p. 234-258.

CATTANEO, A.; MOUSSEAU, B. Empirical analysis of the removal rate of periphyton by grazers. Oecologia, v. 103, n. 2, p. 249-254, 1995. https://doi.org/10.1007/BF00329087

DAFOUZ, R.; CÁCERES, N.; RODRÍGUEZ-GILD, J.L.; MASTROIANNIE, N.; ALDAE, M.L.; BARCELÓ, D.; MIGUEL, A.G.; VALCÁRCEL, Y. Does the presence of caffeine in the marine environment represent an environmental risk? A regional and global study. Science of the Total Environment, v. 615, n. 1, p. 632-642, 2018. https://doi.org/10.1016/j.scitotenv.2017.09.155

DU, B.; HADDAD, S.P.; SCOTT, W.C.; CHAMBLISS, C.K.; BROOKS, B.W. Pharmaceutical bioaccumulation by periphyton and snails in an effluent-dependent stream during an extreme drought. Chemosphere, v. 119, n. 1, p. 927-934, 2015. http://doi.org/927934.10.1016/j.chemosphere.2014.08.044

DUNCK, B.; RODRIGUES, L.; BICUDO, D.C. Functional diversity and functional traits of periphytic algae during a short-term successional process in a neotropical floodplain lake. Brazilian Journal of Biology, São Carlos, v. 75, n. 1, p. 587-597, 2015. https://doi.org/10.1016/j.ecolind.2016.02.060

FERREIRA, P.; SOARES, G.L.G.; D’ÁVILA, S.; BESSA, E.C.A. The Influence of Caffeine and Thymol on the Survival, Growth and Reproduction of Subulina octona (Brugüière, 1789) (Mollusca, Subulinidae). Brazilian Archives of Biology and Technology, Curitiba, v. 52, n. 4 , p. 945-952, 2009. https://doi.org/10.1590/S1516-89132009000400018

FELISBERTO, S.A.; MURAKAMI, E.A. Papel do perifíton na ciclagem de nutrientes e na teia trófica. In: SCHWARZBOLD, A.; BURLIGA, A.L.; TORGAN, L.C. (Eds). Ecologia do perifíton, 1st ed., São Carlos: Rima, 2013. p. 23-44.

FELISBERTO, S.A.; RODRIGUES, L. Dinâmica sucessional de comunidade de algas perifíticas em um ecossistema lótico subtropical. Rodriguésia, v. 63, n.1, p. 463-473, 2012.

FRANCESCHINI, I.M. Chave de identificação dos gêneros de algas (exceto Bacillariophyceae) comumente encontrados no perifíton e metafíton de ambientes aquáticos continentais. In: SCHWARZBOLD, A.; BURLIGA, A.L.; TORGAN, L.C. (Eds). Ecologia do perifíton, $1^{a}$ ed., São Carlos: Rima, 2013. p. 245-266.

FREDHOLM, B.B. Notes on the History of caffeine use. In: FREDHOLM, B.B. Methylxantines (Handbook of experimental pharmacology - 200), $1^{\mathrm{a}}$ ed. Berlin: Springer, 2011. 
B.; KINYUA, J.; MCCALL, A.K.; NUIJS, A.L.N.; PLÓSZ, B.J.; RAMIN, P.; RYU, Y.; SANTOS, M.M.; THOMAS, K.; VOOGT, P.; YANG, Z.; CASTIGLIONI, S. Estimation of caffeine intake from analysis of caffeine metabolites in wastewater. Science of the Total

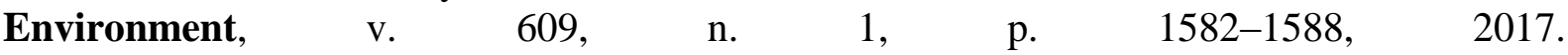
https://doi.org/10.1016/j.scitotenv.2017.07.258

GARDHAN, S.; CHARITON, A.A.; HOSE, G.C. Direct and indirect effects of coppercontaminated sediments on the functions of model freshwater ecosystems. Ecotoxicology, Berlin, v. 24, n. 1, p. 61-70. https://doi.org/10.1007/s10646-014-1355-y

GONÇALVES, E.S.; RODRIGUES, S.V.; SILVA-FILHO, E.V. The use of caffeine as a chemical marker of domestic wastewater contamination in surface waters: seasonal and spatial variations in Teresópolis, Brazil. Revista Ambiente \& Água, Taubaté, v. 12, n. 2, p. 192-202, 2017. http://dx.doi.org/10.4136/ambi-agua.1974

HAMMER, Ø.; HARPER, D.A.T.; RYAN, P.D. PAST: paleontological statistics software package for education and data analysis. Palaeontologia Electronica, v. 4, n. 1, p. 1-9, 2001

HILL, W. Effects of light. In: STEVENSON, R.J.; BOTHWELL, M.L.; LOWE, R.L. (Eds.) Algal ecology: freshwater benthic systems. London: Academic Press, 1996. p. 121-148.

HOMMEN, U.; KNOPF, B.; RÜDEL, H.; SCHÄFERS, C.; GARMAN, E.R.; SCHAMPHELAERE, K.; SCHLEKAT, C. A microcosm study to support aquatic risk assessment of nickel: community-level effects and comparison with bioavailabilitynormalized species sensitivity distributions. Environmental Toxicology and Chemistry, Toronto, v. 35, n. 5, p. 1172 -1182, 2016. https://doi.org/10.1002/etc.3255

IDE, A.H.; CARDOSO, F.D.; SANTOS, M.M.; KRAMER, F.D.; AZEVEDO, J.C.R.; MIZUKAWA, A. Utilização da Cafeína como Indicador de Contaminação por Esgotos Domésticos na Bacia do Alto Iguaçu. Revista Brasileira de Recursos Hídricos, Porto

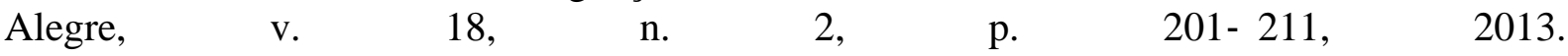

KUMAR, J.; SINGH, V.P.; PRASAD, S.M. An investigation on involvement of the ascorbate-glutathione cycle in modulating $\mathrm{NaCl}$ toxicity in two cyanobacteria photoacclimatized to different photosynthetic active radiation. Algal Research, v. 32, n. 1, p. 70-78, $2017 . \quad$ https://doi.org/10.1016/j.algal.2017.10.019

KUMAR, K.S.; DAHMS, H.U.; LEE, J.S.; KIM, H.C.; LEE, W.C.; SHIN, K.H. Algal photosynthetic responses to toxic metals and herbicides assessed by chlorophyll a fluorescence. Ecotoxicology and Environmental Safety, v. 104, n. 1, p. 51-71, 2014. https://doi.org/10.1016/j.ecoenv.2014.01.042

JACOBS, L.E.; WEAVERS, L.K.; HOUTZ, E.F.; YU-PING, C. Photosensitized degradation of caffeine: Role of fulvic acids and nitrate. Chemosphere, v. 86, n. 2, p. 124-129, 2012. https://doi.org/10.1016/j.chemosphere.2011.09.052

JOHNSTON, N.K.; ZHICHAO, P.; LIN, J. Predator identity influences metacommunity 
assembly. Journal of Animal Ecology, Londres, v. 85, n. 1, p. 1161-1170, 2016. https://doi.org/10.1111/1365-2656.12551

LAMPARELLI, M.C.; TUCCI, A.; SANT'ANNA, C.; PIRES, D.A.; LERCHE, L.H.M.; CARVALHO, M.C.; ROSAL, C. Cianobactérias da região do Alto Tietê. São Paulo: CETESB, 2014. $96 \mathrm{p}$

LAWRENCE, J.R.; BIN, Z.; SWERHONE, G.D.W.; ROY, J.; TUMBER, V.; WAISER, M.J.; TOPP, E.; KORBER, D.R. Molecular and microscopic assessment of the effects of caffeine, acetaminophen, diclofenac and other mixtures on river biofilm communities. Environmental Toxicology and Chemistry, Toronto, v. 31, n. 1, p. 508-517, 2012. https://doi.org/10.1002/etc.1723

LEI, X.; CRUZ, J.A.; SAVAGE, L.J.; KRAMER, D.M.; CHEN, J. Plant photosynthesis phenomics data quality control. Bioinformatics, Oxford, v. 31, n. 11, p. 1796-1804, 2015. https://doi.org/10.1093/bioinformatics/btu854

LIESS, A.; HILLEBRAND, H. Invited review: Direct and indirect effects in herbivore periphyton interactions. Archiv fur Hydrobiolgie, v. 159, n. 4, p. 433-453, 2004. https://doi.org/10.1127/0003-9136/2004/0159-0433

LUDWIG, T.A.V.; TREMARIN, P.I. Chave de identificação dos gêneros de diatomáceas (Diatomae-Ochrophyta) comumente encontrados no perifíton e metafíton de ambientes aquáticos continentais. In: SCHWARZBOLD, A.; BURLIGA, A.L.; TORGAN, L.C. (Eds). Ecologia do Perifíton, $1^{\text {a }}$ ed., São Carlos: Rima, 2013. p. 267-330.

MAHDY, A.; SCHAFENBERGER, U.; ADRIAN, R.; HILT, S. Experimental comparison of periphyton removal by chironomid larvae and Daphnia magna. Inland Waters, Londres, v. 5, n. 1, p. 81-88, 2014. https://doi.org/10.5268/IW-5.1.755

MONTAGNER, C.C.; VIDAL, C.; SODRÉ, F.F.; PESCARA, I.C.; JARDIM, W.F. Cafeína no meio ambiente. In: CANELA, M.C.; JARDIM, W.F.; SODRÉ, F.F.; GRASSI, M.T. (Eds.) Cafeína em águas de abastecimento público no Brasil, $1^{a}$ ed. São Carlos: Cubo, 2014, p. 11-18.

POTVIN, C. ANOVA: experimental layout and analysis. In: SCHNEIDER, S.M.; GUREVITCH, J. (Eds) Design and analysis of ecological experiments. $2^{\mathrm{a}}$ ed, New York: Oxford university press, 2001. p. 63-77.

ROBERTS, M.J.; LONG, S.P.; TIESZEN, L.L.; BEADLE, C.L. Measurement of plant biomass and net primary production. In: COOMBS, J.; HALL, D.O.; LONG, S.P.; SCURLOCK, J.M.O. (Eds). Techniques in bioproductivity and photosynthesis. $2^{\mathrm{a}}$ ed, Oxford: Pergamon Press, 2014. p. 1-19.

ROSI-MARSHALL, E.J.; KINCAID, D.W.; BECHTOLD, H.A.; ROYER, T.V.; ROJAS, M.; KELLY, J.J. Pharmaceuticals suppress algal growth and microbial respiration and alter 
bacterial communities in stream biofilms. Ecological Applications, Washington, v. 23, n. 1, p.

583-593,

2013.

https://doi.org/10.1890/12-0491.1

SAHA, C.; PARVEEN, S.; CHAKRABORTY, J.; PRAMANIK, S.; ADITYA, G. Life table estimates of the invasive snail Physa acuta (Draparnaud, 1805), occurring in india. Ekológia, Bratislava, v. 36, n. 1, p. 60-68, 2017. https://doi.org/10.1515/eko-2017-0006

SHAW, L.; PHUNG, C.; GRACE, M. Pharmaceuticals and personal care products alter growth and function in lentic biofilms. Environmental Chemistry, Acton, v. 12, n. 3, p. 301306 ,

2015.

https://doi.org/10.1071/EN14141

SILANT'EVA, D.I.; GAINUTDINOVA, T.K.; ANDRIANOV, V.V.; GAINUTDINOV, K.L. Electrophysiological studies of the effects of chronic administration of caffeine on the formation of a conditioned defensive reflex in the common Snail. Neuroscience and Behavioral Physiology, v. 39, n. 4, p. 403-407, 2009. https://doi.org/10.1007/s11055-0099136-4

SODRÉ, F.F.; LOCATELLI, M.A.F.; JARDIM, W.F. Occurrence of emerging contaminants in Brazilian drinking waters: A Sewage-To-Tap Issue. Water Air and Soil Pollution, v. 206, n. $1, \quad$ p. $\quad 57-67, \quad 2010$. https://doi.org/10.1007/s11270-009-0086-9

SOUSA, M.L.; CHOW, F.; POMPÊO, M.L.M. Community-level changes in periphytic biofilm caused by copper contamination. Journal of Applied Phycology, 2019. https://doi.org/10.1007/s10811-019-1734-0

STOLER, A.B.; RELYEA, R.A. Leaf litter species identity alters the structure of pond communities. Oikos, v. 125, n. 1, p. 179-191, 2015. https://doi.org/10.1111/oik.02480

TORGAN, L.C.; BERTOLLI, L.M.; TALGATTI, D.M.; SALMONI, S. Colonização e sucessão do perifíton. In: SCHWARZBOLD, A.; BURLIGA, A.L.; TORGAN, L.C. (Eds.) Ecologia do perifíton. São Carlos: Rima, 2013. p. 45-58.

TORRES, P.B.; CHOW, F.; FURLAN, C.M.; MANDELLI, F.; MERCADANTE, A.; SANTOS, D.Y.A.C. Standardization of a protocol to extract and analyze chlorophyll a and carotenoids in Gracilaria tenuistipitata Var. Liui. Zhang and Xia (Rhodophyta). Brazilian Journal of Oceanography, São Paulo, v. 62, n. 1, p. 57-63, 2014. https://doi.org/10.1590/s1679-87592014068106201

TORRES, J.L.T.; HILEY, S.L.; LORIMOR, S.P.; RHOAD, J.S.; CALDWELL, B.D.; ZWEERINK, G.L.; DUCEY, M. Separation of Caffeine from Beverages and Analysis Using Thin-Layer Chromatography and Gas Chromatography-Mass Spectrometry. Journal of Chemistry Education, Washington, v. 92, n. 5, p. 900-902, 2015. https://doi.org/abs/10.1021/ed500977r

UHLENBROOK, S.; ORTIGARA, A.R.C.; CONNOR, R.; ZADEH, S.M. State of water 
resources: Quality and availability. In: UNITED NATIONS WORLD WATER ASSESSMENT PROGRAMME. The United Nations World Water Development Report 2017 - Wastewater: The Untapped Resource. Paris: UNESCO, 2017. p. 9-15.

WETZEL, R.G.; LIKENS, G.E. Limnological Analyses. 2a ed. New York: Springer, 1991. 391

WEYER, K.M.; BUSH, D.R.; DARZINS, A.; WILSON, B.D. Theoretical Maximum Algal Oil Production. Bioenergy Research, v. 3, n. 2, p. 204-213, 2010. https://doi.org/10.1007/s12155-009-9046-X

WINKELMAN, C.; SCHNEIDER, J.; MEWES, D.; SCHMIDT, S.; WORISCHKA, S.; HELLMAN, C.; BENNDOR, J. Top-down and bottom-up control of periphyton by benthivorous fish and light supply in two streams. Freshwater Biology, v. 59, n. 1, p. 803818 , 2014.

YONGHONG, W. Periphyton: Functions and Application in Environmental Remediation. 1 ed. Amsterdam: Elsevier, 2016. 434 p.

ZENCIR, O.; KORKMAZ, A.S. Length-Weight and Length-Length Relationships of Fish Species in Kirmir Stream and its Tributaries (Suveri and Ilhan Stream) of Sakarya River, Turkey. Journal of Applied Biological Sciences, v. 10, n. 1, p. 55-60, 2016. 


\title{
Capítulo 5
}

\section{EFFECTS OF A CONTAMINATED RESERVOIR SUPERFICIAL SEDIMENT ON PERIPHYTON: METAL BIOACCUMULATION AND ECOTOXICITY}

\author{
Sousa, M.L. ${ }^{1}{ }^{*}$; Leal, P.R ${ }^{2}$; Chow, F. ${ }^{3}$; Silva, S.C. ${ }^{4}$, Pompêo, M.L.M. ${ }^{1}$ \\ ${ }^{1}$ Laboratory of Limnology, Department of Ecology, Institute of Bioscience, University of São \\ Paulo. \\ ${ }^{2}$ Division of Remote Sensing, National Institute of Spatial Research - INPE. \\ ${ }^{3}$ Laboratory of Marine Algae "Édison José de Paula", Department of Botany, Institute of \\ Bioscience, University of São Paulo. \\ ${ }^{4}$ Environmental Sciences Program, São Paulo State University “Júlio de Mesquita Filho”.
}

\section{Acknowledgements:}

This work was supported by the scholarship Coordenação de Aperfeiçoamento Pessoal de Nível Superior (Finance code 001) and the Fundação de Amparo á Pesquisa do Estado de São Paulo research grant (2014/22581-8). Fungyi Chow thanks Conselho Nacional de Desenvolvimento Científico e Tecnológico for the productivity fellowship (303937/2015-7).

*Manuscrito submetido ao periódico Ecotoxicology. 


\section{Resumo}

Os metais são contaminantes altamente densos e que se decantam facilmente no sedimento de reservatórios. Esses compostos adentram a cadeia alimentar num processo chamado de biomagnificação. O ponto de entrada é através da predação de produtores primários contaminados, especialmente algas perifíticas, uma vez que esse grupo é especialmente conhecido por sua capacidade de reter contaminantes na sua mucilagem. Esse estudo avaliou a bioacumulação de metais no perifíton após a exposição a um sedimento contaminado de um reservatório urbano. Através de um teste ecotoxicológico, foi avaliada a produção de biomassa seca livre de cinzas, clorofila-a, análises fotossintéticas através de fluorômetro e bioacumulação de metais após a contaminação pelo sedimento. Os resultados mostraram que apesar de não serem observadas alterações na produção de biomassa e concentração de clorofila-a, a comunidade apresentou alterações fisiológicas, como observado nas análises fluorimétricas. Isso indica mudanças na composição e funcionamento do biofilme. As curvas de bioacumulação mostraram que $\mathrm{Cu}, \mathrm{Ni}$ e $\mathrm{Mn}$ foram altamente assimilados pelo perifíton. Esses resultados são sinais da ação antrópica, especialmente do $\mathrm{Cu}$, provindo das aplicações frequentes de $\mathrm{CuSO}_{4}$ como algicida no reservatório amostrado. A contaminação por Ni também pode ser ligada á atividade industrial nos arredores do reservatório. $\mathrm{O}$ impacto biológico resultante da absorção desses metais pelo biofilme pode afetar tanto a composição do perifíton quanto a cadeia alimentar baseada nesse grupo, devido a perda de espécies palatáveis e intoxicação por metais.

Palavras-chave: Biomagnificação, Monitoramento de Ecossistemas, Microalgas, Microcosmos. 


\begin{abstract}
Reservoirs are complex ecosystems subject to several sources of pollutants. Metals are highly dense contaminants that easily decant in the sediment of reservoirs, and the disposal of industrial effluents usually lead to a high concentration of metals in water. These compounds can pass through the food chain in a process called biomagnification. The point of entry is through predation of contaminated primary producers, especially periphytic algae, known for their capacity to accumulate metals in the mucilaginous portion of the biofilm. This study evaluated metal bioaccumulation of periphyton after exposure to a sediment matrix from a metal contaminated urban reservoir. Using an ecotoxicological test, we evaluated biomass production through ash free dry mass weight, chlorophyll-a concentration, photosynthetic analysis using a fluorometer, and metal bioaccumulation after contamination. Results showed that even though there were no alterations in biomass production and chlorophyll-a content, the community changed physiologically as observed in fluorometer analysis, indicating changes in community composition and functioning. Bioaccumulation curves showed that $\mathrm{Cu}$, $\mathrm{Ni}$ and Mn were highly assimilated by the biofilm. These are clear results of anthropic activity, especially for $\mathrm{Cu}$, which comes from frequent copper sulphate applications in the area as algicide for toxic cyanobacteria. Ni contamination can be linked to industrial and metallurgical activities in the area close to the reservoir. The biological impact resulting from the absorption of these metals can affect both periphyton composition, and cause an imbalance in the food chain due to the loss of species from contamination or metal intoxication.
\end{abstract}

Keywords: Biomagnification, Ecosystem monitoring, Microalgae, Microcosms. 


\section{Introduction}

Reservoirs are complex ecosystems created by man through damming of rivers with transitional characteristics from the frames, rivers and lakes (POMPÊO et al., 2015). The main roles of reservoirs are water supply for humans, cattle, crop irrigation, power generation, recreational purposes, and navigation (RIBEIRO et al., 2016). Due to the proximity to anthropic activity, reservoirs are subject to several sources of pollutants: domestic sewage, industrial effluents, and solid waste disposal. In the countryside, the disposal of pesticides and agricultural waste is also present (ROSA et al., 2015). The contaminants present in domestic sewage alone are microorganisms, pharmaceuticals, personal care products, caffeine, and hormones (MELVIN \& LEUSH, 2016). In industrial effluents, dyes, metals, petroleum products, and extreme pH values are present (ABID et al., 2015; JAFARINEJAD, 2017; LIU et al., 2015).

The sediment from the reservoir is especially sensitive to contamination when compared to the water column insofar as reservoirs are lentic ecosystems, leading to decantation of denser compounds which accumulate over the superficial layer of sediment (MELO et al., 2012). These harmful components can be resuspended due to water column recirculation cycles or sediment movement (SILVA et al., 2017). In both cases, the result is a contamination pulse of the local system, causing much damage to ecosystem functioning (PILSKALN et al., 1998; Brodersen et al., 2017).

Metals are highly dense contaminants that easily decant in the sediment of reservoirs (MELO; et al. 2012). They can enter the water column from natural sources, such as geological processes, but contamination frequently comes from anthropic activity (SILVA et al., 2017). In urban reservoirs, the disposal of industrial effluents and solid wastes usually leads to a high concentration of metals in water (LIU et al., 2012). The effects of contamination can vary depending on the metal and organism affected. According to Authman et al. (2015), the most common consequences observed in fishes are: damage to respiratory, neurological and digestive systems, destruction of blood cells, osmotic imbalance, necrosis, organ degeneration and death. Moreover, metals are bioaccumulative substances, and can pass through the food chain in a process called biomagnification, reaching top consumers. The point of entry is through predation of contaminated primary producers, especially periphytic algae. 
The periphyton complex is known for its capacity to accumulate metals on the mucilaginous portion of the biofilm, reaching higher concentrations than the surrounding environment. After exposure to a significant concentration of metals, periphyton passes to the consumers on the next trophic level, composed of several species of vertebrates and invertebrates such as herbivore fishes, chironomidae, caddisflies, mayflies, amphibians, and snails (WINKELMAN et al., 2014; GARDHAN et al., 2015). Thereby, insight about the potential damage of metal pollutants to the periphyton community is fundamental in understanding the effects of water pollution on a large scale.

Considering this, our study aims to evaluate the metal bioaccumulation in a periphyton community after exposure to a sediment matrix from a metal contaminated urban reservoir. Through an ecotoxicological test with the periphyton cultivated in laboratory, we expect to understand how the composition of the sediment can influence the metal concentration in periphyton, and which metals are more likely to accumulate in the biofilm. For this, we evaluated biomass production through ash free dry mass weight, chlorophyll-a concentration, photosynthetic effective quantum yield, and rapid light curves of the community after contamination. Bioaccumulation was evaluated separately for each metal through atomic emission spectrometry analysis. With the results, we expect to obtain useful data for water management of reservoirs, especially ones in a similar situation as the Guarapiranga Reservoir, which presents diffuse contamination sources and is located near large urban centers.

\section{Methodology}

\section{Study Area}

Guarapiranga Reservoir (Figure 1) is located in the São Paulo metropolitan area (Brazil), and is responsible for water supply, power generation, and recreation (RODRIGUES et al., 2017). Created in 1906, nowadays the reservoir is completely surrounded by urban area. São Paulo city alone accounts for $70 \%$ of its perimeter, which is filled with houses, country houses, and buildings (ARRUDA et al., 2016). Even though the city of São Paulo corresponds to the largest part of the reservoir's perimeter, the cities of Embu-Guaçu, Itapecerica da Serra, Juquitiba, and São Lourenço da Serra also surround the reservoir and present higher 
abstention when it comes to sewage treatment. Therefore, these cities correspond to a large part of the released contaminated water (OTOMO, 2015). It is estimated that only $50 \%$ of the houses around the reservoir are actually connected to the sewage system (GARCIA, 2017), with the remaining waste being discarded directly into the reservoir as raw sewage. Moreover, there is a continuous discharge of industrial effluents from diffuse sources, solid waste disposal, and erosion (POMPÊO et al., 2013), generating a complex scenario of pollution at the bottom surface of the sediment.

Regarding metal contamination, there is a constant release of waste containing cadmium, copper, nickel, and lead through anthropic activities. However, the natural geological composition of the area also includes aluminum and iron, which are also present in surface sediments (SILVA et al., 2017). Copper especially comes from the constant application of $\mathrm{CuSO}_{4}$ in algicide used to control algal blooms. This caused the accumulation of elevated concentrations of this metal in surface sediment and the water column, as described by Pompêo et al. (2013) and Silva et al. (2017).

Figure 1: Location of the Guarapiranga Reservoir situated in São Paulo City, São Paulo Brazil, where the sampling area is located

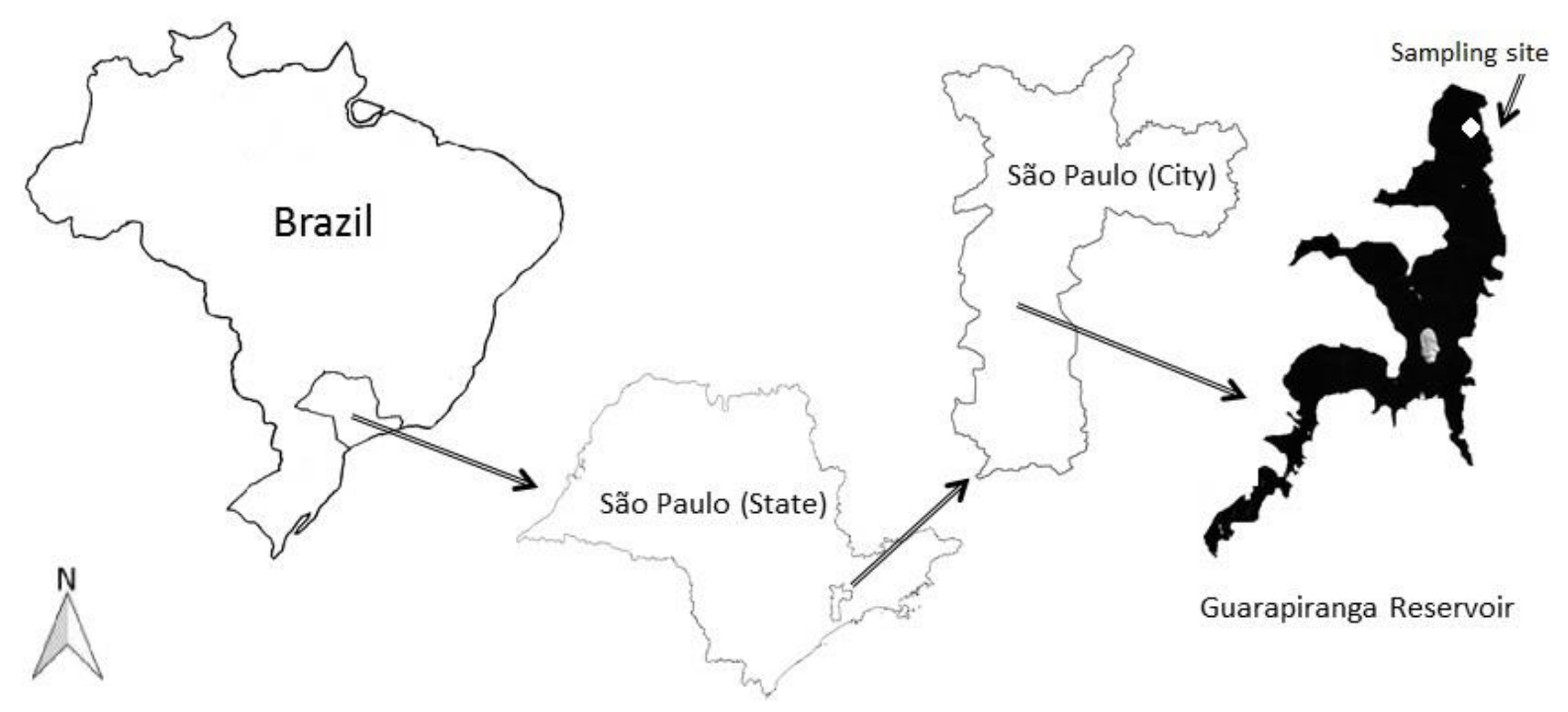




\section{Sampling, processing and characterization of the sediment}

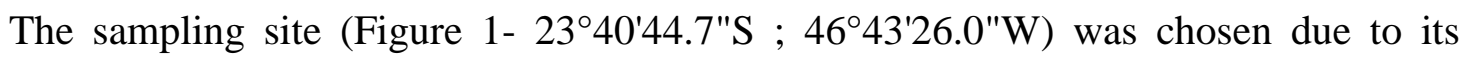
proximity to the dam, next to the urban area, with navigation activity and a high rate of contamination (SILVA, 2013). Thus, a wider pool of metals and organic matter would be present in sediment. Sediment was obtained according to Schropp et al. (1990) and immediately conditioned in plastic recipients for laboratorial analysis. After removing the interstitial water, the sediment was dried in a drying oven until weight stabilization, and then the total organic matter was measured according to Meguro (2000). Metal content was quantified using an atomic emission spectrometer (ICP-AES Inductively Coupled Plasma Atomic Emission Spectrometry). The remaining sediment was reserved for ecotoxicological tests.

\section{Periphyton cultivation for ecotoxicological tests}

An initial aliquot of periphyton was collected in a small pond at the São Paulo University campus ( $\left.23^{\circ} 33^{\prime} 55^{\prime \prime} \mathrm{S} 46^{\circ} 43^{\prime} 51^{\prime \prime} \mathrm{W}\right)$ and inoculated in artificial substrate on $154 \mathrm{~cm}^{2}$ plastic round slides (SOUSA et al. 2019). After 21 days, the grown inoculum was removed from the slides using a soft brush and deionized water, transferred to $50 \mathrm{~L}$ culture tanks and cultivated in laboratory with culture medium L.C. Oligo (ASSOCIAÇÃO BRASILEIRA DE NORMAS TÉCNICAS, 2018). Also, $36.65 \mathrm{~cm}^{2}$ glass slides were used as artificial substrate for periphyton colonization (SCHMITT-JANSE et al., 2016). Complete composition of L.C. Oligo is available on Supplementary Material. Light was provided by $16 \mathrm{~W}$ fluorescent lamps operating in $12 \mathrm{~h}$ photoperiods. Oxygenation and water circulation were maintained using 3 W air pumps (model s2000, Boyu) and air curtain diffusers. Temperature was controlled at $26^{\circ} \mathrm{C}$ using a thermostat (model At-100, Atmam). Laboratory cultivation lasted for 21 more days (TORGAN et al., 2013), after which the glass slides were colonized with an homogeneous layer of periphyton, and then ready for the ecotoxicological test. 


\section{Ecotoxicological test}

The previously colonized glass slides were placed vertically inside $1.5 \mathrm{~L}$ plastic vessels in groups of seven. The vessels were then filled up with L.C. oligo medium and the designated dried sediment concentration according to Table 1. Since the total sediment concentration also affects the water turbidity, previously calcined quartz sand (Aqua Pedras) with similar granulometry as the sediment was used to balance the amount of particulate matter between the different treatments. Tests were mounted in triplicate, using four different sediment concentrations plus a control, with a total of 15 plastic vessels.

Table 1: Treatments of sediment exposure for the ecotoxicological test using periphyton inocula.

\begin{tabular}{cccc}
\hline Treatment & Sediment $(\mathrm{g})$ & Sterile Sand $(\mathrm{g})$ & Sediment $(\mathrm{g} / \mathrm{L})$ \\
\hline Control & 0 & 4 & 0 \\
I & 1 & 3 & 0.7 \\
II & 2 & 2 & 1.3 \\
III & 3 & 1 & 2 \\
IV & 4 & 0 & 2.6 \\
\hline
\end{tabular}

Exposure period was 15 days, using the same light and oxygenation conditions as culture tanks. After that, glass slides were removed from the vessels and the periphyton was collected using a soft brush and deionized water. Finally, samples were separated for the different analytical procedures.

\section{Ash free dry mass (AFDM) and chlorophyll-a (Chl-a)}

Quantification of AFDM was made by drying the previously collected periphyton samples in an oven at $65^{\circ} \mathrm{C}$ until weight stabilization, followed by calcination in a muffle furnace at $450{ }^{\circ} \mathrm{C}$ (ROBERTS et al., 2014). Chl-a concentration was obtained by filtering the samples through glass fiber filters (Millipore AP40), followed by maceration using 90\% acetone. The resulting material was centrifuged, and the supernatant read in a 
spectrophotometer (TORRES et al., 2014). Both analyses were performed in triplicate for each treatment, with a total of 15 samples.

\section{Effective quantum yield (YII) and light saturation point (Ik)}

The YII was measured in vivo using a Pulse Amplitude Modulation fluorometer (PAM-2500, Waltz). Measures were performed in triplicate for each treatment, directly on the colonized glass slides. The light fiber was positioned over the slides containing the periphyton and the saturated luminous pulse activated, measuring the YII. Rapid light curves were performed to assess relative electron transport rate (ETRr) after dark acclimation of the samples for 15 minutes (KUMAR et al., 2014). From the rapid light curves, Ik was inferred (WEYER et al., 2010).

\section{Metal accumulation on biofilm}

Quantification of the bioaccumulation of metals present in the sediment was performed in triplicate for each treatment, through digestion in $\mathrm{HCl}$ followed by spectrometer analysis (INTAWONGSE \& DEAN, 2006). All the glassware used was previously washed in nitric acid $10 \%$ for $24 \mathrm{~h}$, and then rinsed three times in deionized water. Samples were then transferred to glass beakers containing $2.0 \mathrm{~mL}$ of $\mathrm{HNO}_{3}(1 \mathrm{~N})$ and $5.0 \mathrm{~mL}$ of $\mathrm{HCl}(1 \mathrm{~N})$. Samples were digested in sand bath $\left(90^{\circ} \mathrm{C}\right)$ until a $20 \mathrm{~mL}$ volume, normalized with deionized water to $50 \mathrm{~mL}$ and filtered in glass fiber filters (Millipore AP40). Afterwards, samples were analyzed in an atomic spectrometer (ICP-AES Inductively Coupled Plasma - Atomic Emission Spectrometry).

\section{Data Analysis}

Significant differences among the treatments for AFDM and Chl-a were verified through one-way ANOVA followed by Tukey's test, $p<0.05$ (POTVIN, 2001), using OriginPro 8.5 (OriginLab). Normality and homoscedasticity were tested using Bartlett's test and Kolgomorov Smirnov's test, respectively. Artwork for AFDM, Chl-a, YII and Ik were created using OriginPro 8.5. Bioaccumulation was modeled and calculated using 
Kaleidagraph 4.0 software (Synergy®), which was also used for creating the respective artwork for these analysis.

\section{Results}

Characterization of the sediment

Sediment from the sampled site had $25.3 \%$ organic matter content. Regarding the metals, eight were found ( $\mathrm{Al}, \mathrm{Cd}, \mathrm{Pb}, \mathrm{Cu}, \mathrm{Cr}, \mathrm{Fe}, \mathrm{Mn}$, and $\mathrm{Ni}$ ) and summarized in Table 2.

Table 2: Composition and abundance of metals identified from the sampled sediment.

\begin{tabular}{cc}
\hline Metal & $\mathrm{mg} / \mathrm{g}$ of sediment \\
\hline Aluminum $(\mathrm{Al})$ & 76.690 \\
Cadmium $(\mathrm{Cd})$ & 0.002 \\
Lead $(\mathrm{Pb})$ & 0.070 \\
Copper $(\mathrm{Cu})$ & 2.984 \\
Chrome $(\mathrm{Cr})$ & 0.039 \\
Iron $(\mathrm{Fe})$ & 60.385 \\
Manganese $(\mathrm{Mn})$ & 0.916 \\
Nickel $(\mathrm{Ni})$ & 0.052 \\
\hline
\end{tabular}

Ash free dry mass (AFDM) and chlorophyll-a (Chl-a)

A wide variation of AFDM and Chl-a was observed among the samples (Fig. 2). Nonspecific tendency was observed with the increased sediment concentration, resulting in no significant difference between the treatments. 
Figure 2 Content of AFDM and Chl-a for periphyton cultivated at different sediment concentrations

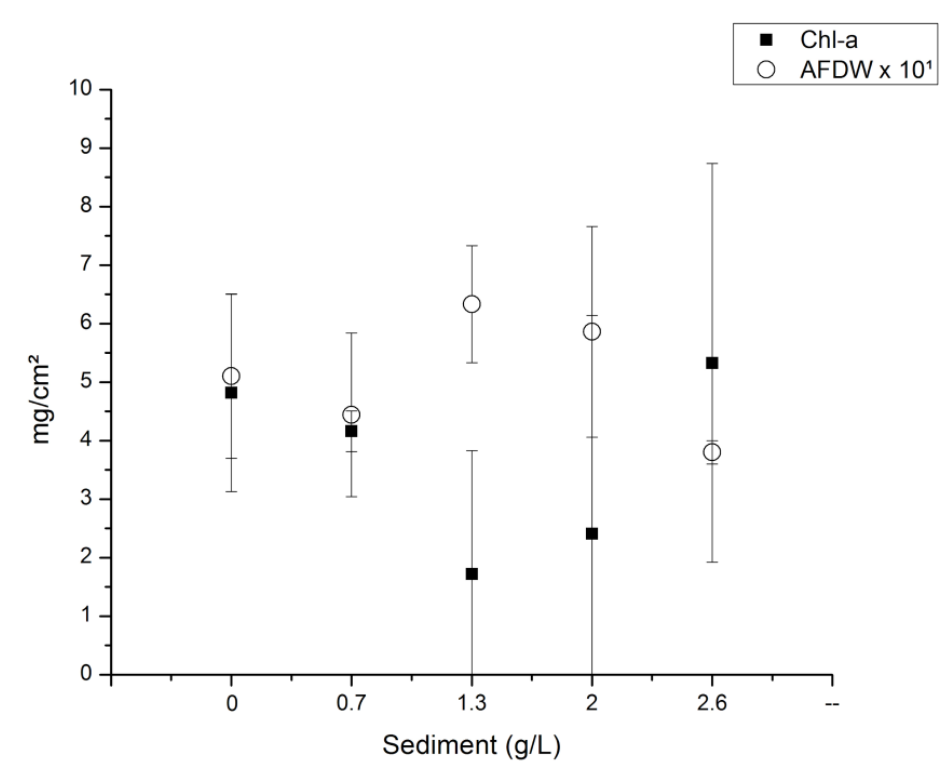

Effective quantum yield (YII) and light saturation curve

Regarding YII of the periphyton, no significant variation among the treatments was observed at different sediment concentrations (Fig. 2a). However, the rapid light curves showed differences among the treatments (Fig. 2b). Control and $2.6 \mathrm{mg} / \mathrm{L}$ presented saturation at $108 \mu \mathrm{mol}$ photons $\mathrm{m}^{-2} \mathrm{~s}^{-1}$, while $1.3 \mathrm{mg} / \mathrm{L}$ showed saturation at $186 \mu \mathrm{mol}$ photons $\mathrm{m}^{-2} \mathrm{~s}^{-1}$. The remaining $0.7 \mathrm{mg} / \mathrm{L}$ and $2.0 \mathrm{mg} / \mathrm{L}$ showed saturation at a higher point, $301 \mu \mathrm{mol}$ photons $\mathrm{m}^{-2} \mathrm{~s}^{-1}$. Major ETRr x PAR kinetic was observed at $2 \mathrm{~g} / \mathrm{L}$ of sediment. Moreover, with the increase of sediment concentration, the inferred ETRmax and Ik was higher than the Control treatment (Fig. 2b). 
Figure 3 Effective quantum yield (YII) (a) and rapid light curve (ETRr x PAR) (b) for periphyton cultivated at different sediment concentrations

(a)

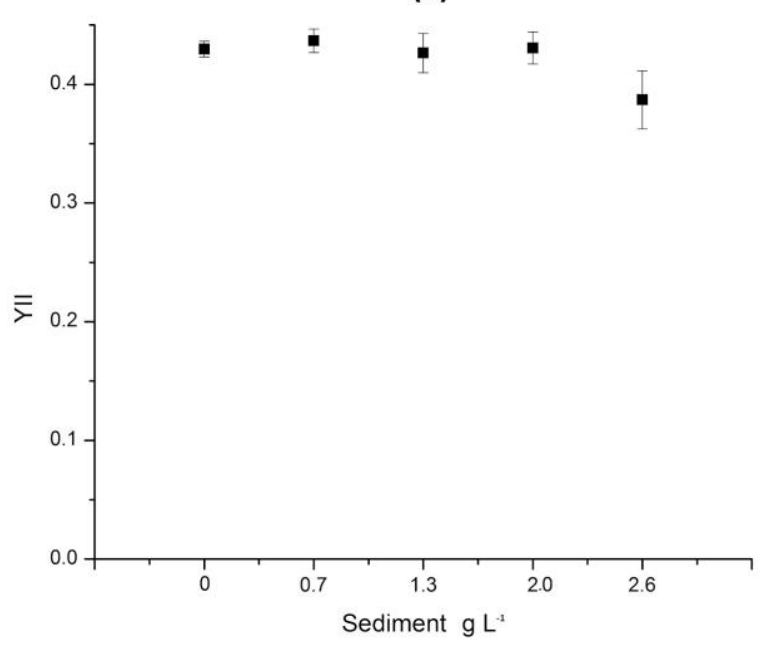

(b)

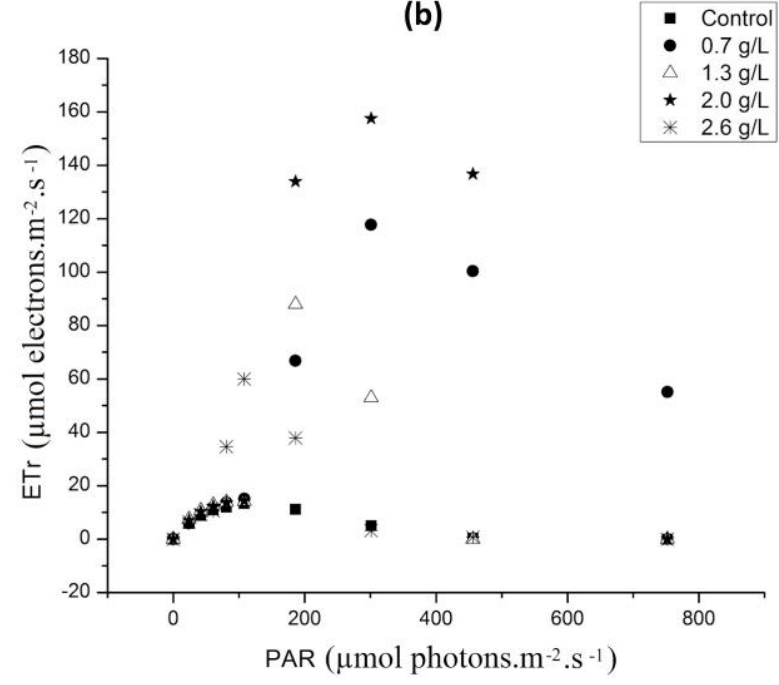

Metal bioaccumulation

Six out of the eight metals identified in the sediment (Table 1) were also identified in the periphyton biofilm: $\mathrm{Al}, \mathrm{Cu}, \mathrm{Cr}, \mathrm{Fe}, \mathrm{Mn}$ and $\mathrm{Ni}$. $\mathrm{Cd}$ and $\mathrm{Pb}$ were not identified with the procedure used in this study (ICP-AES). The correlation trends between sediment concentration and metal concentration in the biofilm were different for each metal (Fig. 4). For $\mathrm{Al}$, the correlation was negative with a moderate correlation coefficient $(\mathrm{R}=0.56652)$ For $\mathrm{Cr}$, a positive and weak linear correlation was observed $(\mathrm{R}=0.36922) . \mathrm{Cu}, \mathrm{Mg}$ and $\mathrm{Ni}$ showed strong positive correlations $(\mathrm{R}>0.9)$. Fe showed a moderate positive correlation $(\mathrm{R}$ $=0.63)$. 
Fig 4 Bioaccumulation curves for periphyton cultivated at different sediment concentrations.
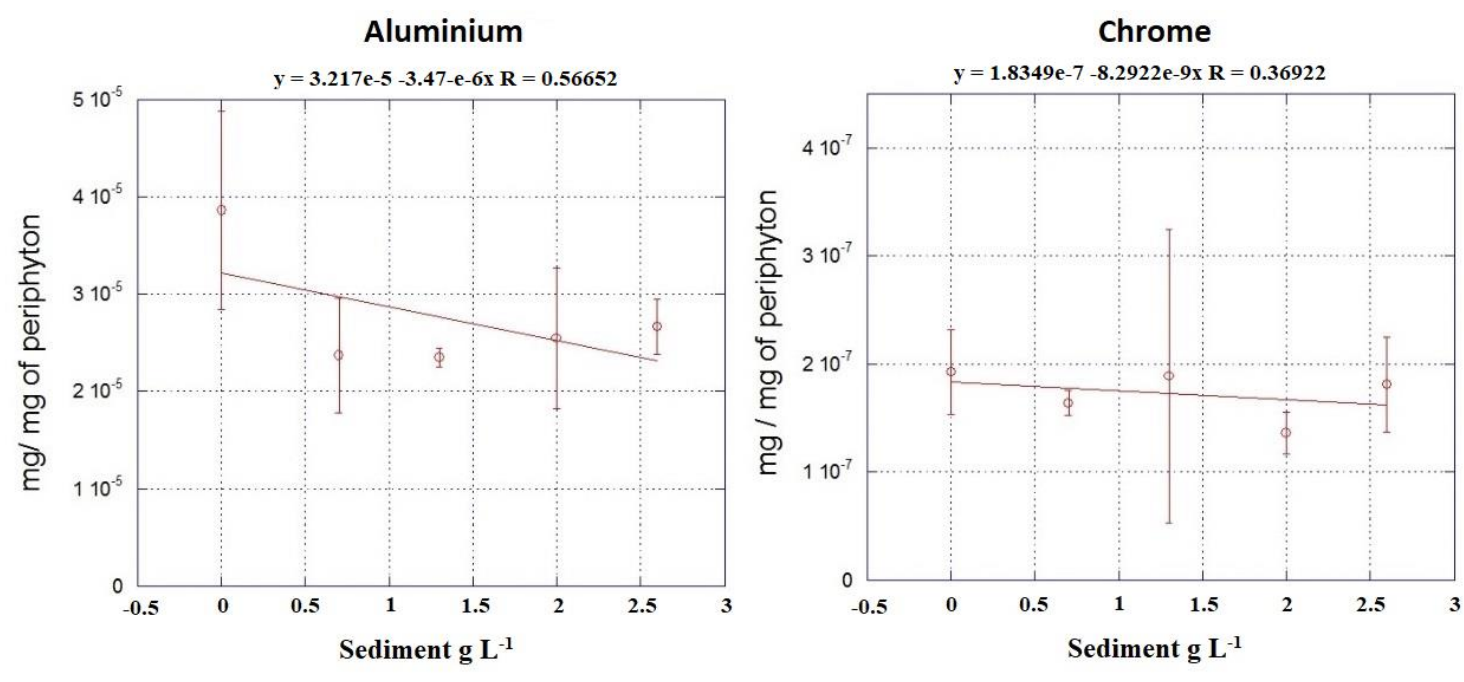

Copper
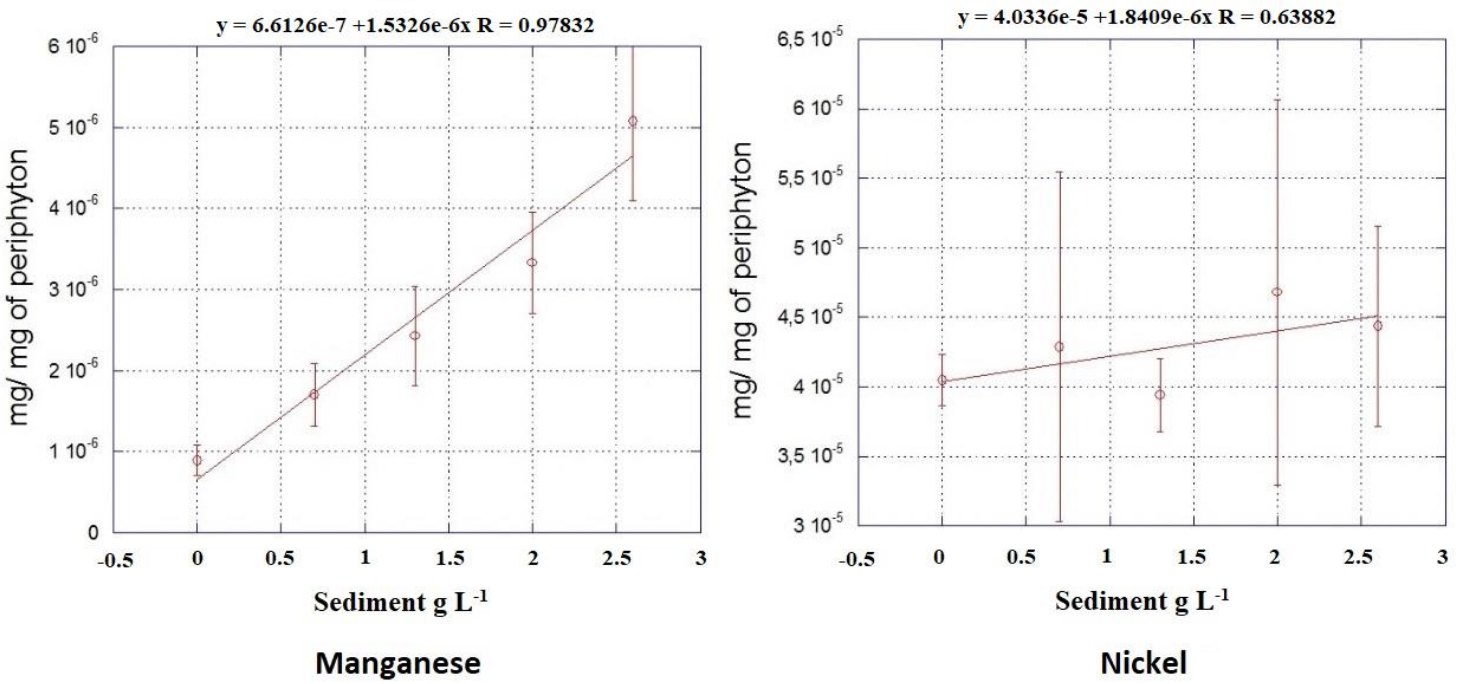

Nickel
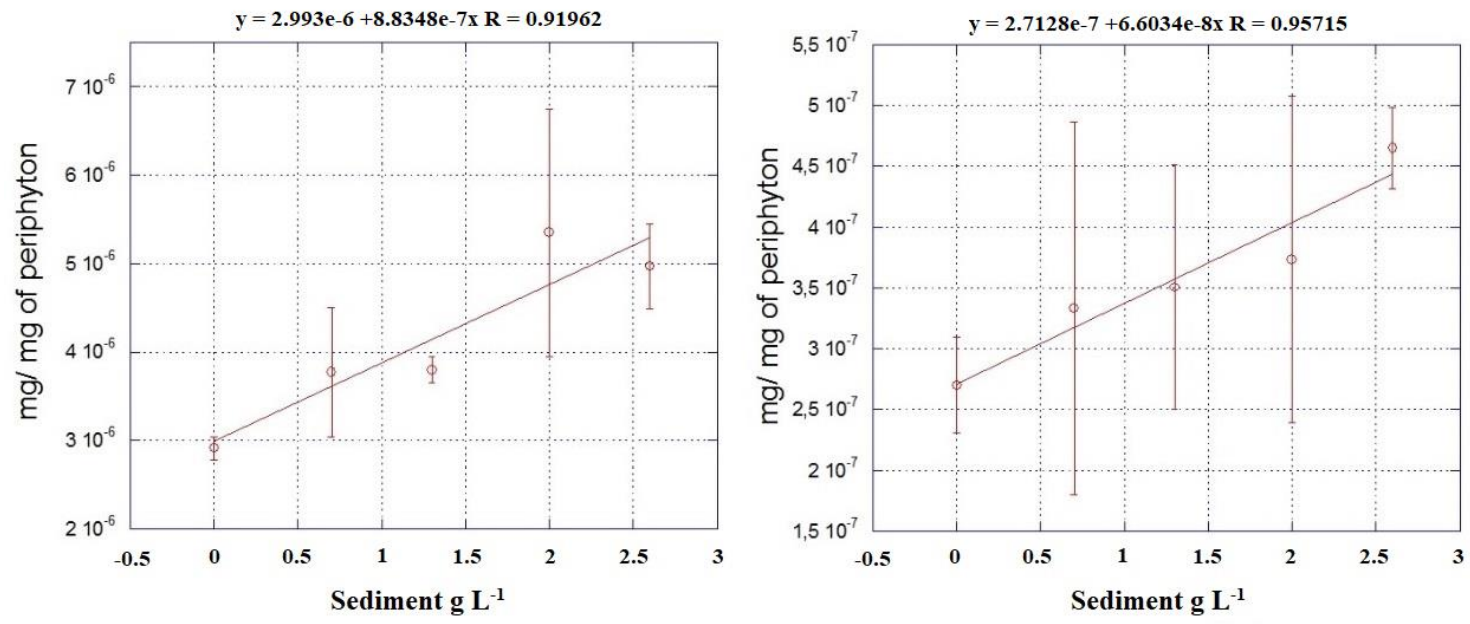


\section{Discussion}

Elevated concentrations of metals and organic matter were measured in the sediment from the Guarapiranga Reservoir. The high concentrations of $\mathrm{Fe}$ and $\mathrm{Al}$ are justified considering the geographical characteristics of the study area (POMPÊO et al., 2013). However, the high concentrations of other metals, particularly $\mathrm{Cu}$, are due to human interference. This last result was expected considering the historical use and occupation of the area, with frequent uses of algicide to reduce the proliferation of algae (SILVA et al., 2017). According to Leal et al. (2018), the concentration of $\mathrm{Cu}$ found in the Guarapiranga Reservoir is comparable to that found in tailing ponds. Moreover, the surrounding area is also affected by discharge of industrial effluents, untreated domestic sewage, fuel from ships, and mining activities (LEAL, 2017).

Both AFDM and Chl-a were not significantly different among the treatments, even though the increase of sediment concentration implied a direct increase in organic matter. Since the sediment showed a content of $25 \%$ organic matter, it should enrich the water, leading to a higher growth of biofilm. However, in this case, the increase of organic matter content was followed by an increase in metals concentration, at the same rate. Therefore, the effects of metal contamination stood out in comparison to the organic matter enrichment effects in periphyton.

The effects of contamination can also be observed in the light saturation curves, where the presence of the sediment in all concentrations altered the Ik of the periphyton, shifting the kinetic curves to increasing levels of ETRr. Particularly, the treatments at $0.7 \mathrm{~g} / \mathrm{L}$ and $2.0 \mathrm{~g} / \mathrm{L}$ showed inferred Ik values of 186 and $301 \mu \mathrm{mol}$ photons $\mathrm{m}^{-2} \mathrm{~s}^{-1}$,respectively, while Control and $2.6 \mathrm{~g} / \mathrm{L}$ treatments showed $108 \mu \mathrm{mol}$ photons $\mathrm{m}^{-2} \mathrm{~s}^{-1}$. The alteration of photosynthetic performance in the growing periphyton is a direct reflection of the community composition, indicating structural dominance changes, since the shape of the light curve, as well as its Ik's values, are dependent on the species present in the biofilm (LEI et al., 2015). According to Cheyloni and Slaveykova (2018), there is a close relation between metal concentration, light harvest, and the presence of certain species in periphyton. Since laboratorial light was constant in this experiment, speciation process was caused by the presence of metal, which in turn lead to different metal absorption rates.

Maximum ETR found was also higher at elevated sediment concentrations, even though Chl-a values were the same. In the highest concentration studied (treatment at 2.6 
$\left.\mathrm{g} / \mathrm{L}^{1}\right)$ there was a severe drop in ETR when compared to the previous one $(2.0 \mathrm{~g} / \mathrm{L})$, dropping from 157.52 to $60.01 \mu \mathrm{mol}$ electrons $\mathrm{m}^{-2} \mathrm{~s}^{-1}$. The alterations in light curves could indicate a physiological change in the community, likely due to the dominance modification from structural changes of the community, resulting from the high concentration of metals, especially copper (SOUSA et al., 2019).

Bioaccumulation evaluation, the last parameter studied, is an important tool for estimating cascade effects of contaminants in food chains, especially regarding periphyton, which is a producer in reservoirs and can act as an entrance way for metals to higher trophic levels (TANG et al., 2014). Considering this, the incidence of bioaccumulation in the periphyton exposed to the sediment in laboratory is an important indicator of the processes occurring in the reservoir itself. Bioaccumulation was even observed at low exposure of sediment concentration $\left(0.7 \mathrm{~g} / \mathrm{L}^{1}\right)$, showing the susceptibility of the microalga community present in the periphyton biofilm. The correlation between sediment concentration and metal concentration in biofilm was different for each metal. According to Jiali et al. (2016), when in the presence of various metals, biofilm preferably absorbs some of the metals due to chemical and biological characteristics, creating different concentration curves.

Six out of eight metals were identified in periphyton, however, $\mathrm{Al}$ and $\mathrm{Fe}$ are naturally found in high concentrations in the water due to natural geological characteristics of the Guarapiranga reservoir (SILVA et al., 2017).

The accumulation of $\mathrm{Al}$ in biofilm depends both on the community composition and on low $\mathrm{pH}$ values (SANTOS, 2003). Considering the $\mathrm{pH}$ of the experiment was $\sim 7.0$ and the correlation between sediment concentration and metal in biofilm was negative, the periphyton was not prone to $\mathrm{Al}$ contamination in this study. Iron showed a weak and positive correlation, with a maximum concentration of $60 \mathrm{mg} / \mathrm{kg}$ of dry mass of periphyton. This concentration still conforms with standards for plants, which is $208 \mathrm{mg} / \mathrm{kg}$ of dry mass (LIMA, 2003). However, Fe in algae can cause physical damage instead of direct toxic effects, because the deposition of iron oxides in periphyton is responsible for reducing the interstitial space within the biofilm (CADMUS et al., 2018). Furthermore, the presence of Fe is usually associated with other metals, such as Mn (MARTINS, 2003) and Cu (CADMUS et al., 2018), which were also identified in both the sediment and biofilm. Thus, even though Fe does not cause direct damage to the periphyton alone, it could be linked to synergic effects of contamination.

Another metal identified in the periphyton was $\mathrm{Cr}$, with a negative and weak correlation between sediment concentration and presence in periphyton. According to Silva 
(2003), solubility and bioavailability of $\mathrm{Cr}$ are inversely proportional to organic matter presence. So, the increasing presence of organic matter caused by the sediment concentration was responsible for blocking the $\mathrm{Cr}$ absorption.

The last three metals $(\mathrm{Cu}, \mathrm{Mn}, \mathrm{Ni})$ were strongly bioaccumulated in periphyton, with a linear correlation between sediment availability and concentration in periphyton with $\mathrm{R}>0.9$. According to Martins (2003), Mn is easily accumulated by the microalgae of periphyton and used for the complexation of $\mathrm{Cu}$ and $\mathrm{Ni}$ ions, which explains the similar bioaccumulation curves for the three metals. This also means that $\mathrm{Mn}$ presence is a limiting factor to $\mathrm{Cu}$ and $\mathrm{Ni}$ bioaccumulation. A similar result of linked accumulation curves was observed by Tang et al. (2014). Mn is widely found in environments due to natural sources associated with iron ore or human activity, such as industry effluents and fuels (MARTINS, 2003). Since the Guarapiranga Reservoir is in an urban area (POMPÊO et al., 2013), it is a considerable source of $\mathrm{Mn}$ in water, along with the high natural concentration of Fe. In periphyton, $\mathrm{Mn}$ acts as an essential PSII cofactor (JINSHUI et al., 2015). This effect can be observed in ETR results, leading to an increase in photosynthetic activity when in the presence of the sediment. According to Scheibener et al. (2017), transference of Mn between trophic levels is low, so the effects of accumulation would be restricted to the biofilm.

When observing $\mathrm{Ni}$ results, this metal is also considered an indicator of human activity, as it is closely related to the metallurgy industry (OLIVEIRA, 2003), found in the area surrounding the Guarapiranga Reservoir (GARCIA, 2017). Even though bioaccumulation of $\mathrm{Ni}$ in periphyton was identified in this study, this metal is barely absorbed through ingestion by periphyton predators (OLIVEIRA, 2003). Therefore, its presence mainly serves as an indicator of use and occupation of the area. However, it still can damage periphyton, leading to the substitution of more sensitive species due to the process of pollution induced community tolerance (LAMBERT et al., 2015).

The last metal identified, $\mathrm{Cu}$, showed the highest correlation of sediment concentration and metal concentration in the biofilm $(R=0.97)$, evidencing a considerably high affinity between periphyton and $\mathrm{Cu}$. This result is very important because the availability of $\mathrm{Cu}$ in the Guarapiranga Reservoir is high due to human activity, exclusively. After several years of copper sulphate applications as algicide (SILVA et al., 2017), it created a significant source of contamination in the aquatic biota. Moreover, the presence of Fe and Mn helps the absorption of $\mathrm{Cu}$ by the biofilm, increasing the problem (CADMUS et al. 2018; TANG et al., 2014). Besides being an essential metal in low concentrations, $\mathrm{Cu}$ is responsible for several toxic 
effects after excessive exposure (PEDROZO, 2003). The highest concentration used in the treatment of $2.6 \mathrm{~g} / \mathrm{L}$ was responsible for $3.9 \mathrm{mg} / \mathrm{L} \mathrm{of} \mathrm{Cu}$ in water. When in contact with the biofilm, this resulted in a concentration of $5 \times 10^{-6} \mathrm{mg}$ of $\mathrm{Cu} / \mathrm{mg}$ of dried biomass, or $5 \mathrm{ppm}$. According to Pedrozo (2003), Cu concentration above $0.1 \mathrm{ppm}$ can already affect the growth of green and blue algae; however there was no significant difference between AFDM or Chl-a values among the different treatments. This indicates a substitution of the species more susceptible to $\mathrm{Cu}$ for other, more resistant groups, according to the concept of pollution induced community tolerance (LAMBERT et al., 2015). However, $\mathrm{Cu}$ can still cause damage to these resistant species, especially for diatoms. According to Pandey and Bergey (2015), diatom habitats highly contaminated by $\mathrm{Cu}$ present lower motility and high rates of malformation. The bioavailability of copper to the algae is also linked to the process of speciation. This process occurs when $\mathrm{Cu}$ reacts with other substances in water, forming compounds with lower bioavailability (TAKAMURA-ENYA \& TOKUTAKE, 2016), since the most toxic form of $\mathrm{Cu}$ is its free ion $\mathrm{Cu} 2+$ (BREAULT et al., 1996). Thus, it can interfere in toxicological results, underestimating the effects of $\mathrm{Cu}$ in the periphyton. The culture media L.C. Oligo also contains Citric Acid (Table I - Supplementary Material), which is a metal chelator and could cause speciation (HAMADA et al., 2015). However, speciation caused by citric acid is severe in $\mathrm{Cu}$ : Citric acid ratios close to 1:1 (KABRA et al., 2008), which is not the case for the experiments herein. Even in the lowest concentration of sediment used in treatment $\mathrm{I}(0,7 \mathrm{~g} / \mathrm{L})$, the ratio was $35: 1$, so the speciation caused by the experimental conditions are not relevant. However, since Guarapiranga is contaminated with a mixed matrix of substances (POMPÊO et al., 2015), which were not the focus of this study, the effects caused by a possible speciation should be considered.

In relation to the predators of periphyton, small fishes, such as Gobio gobio that can weight about $2 \mathrm{~g}$ (WINKELMAN et al., 2014), are prone to suffer $\mathrm{Cu}$ contamination effects starting at $3.0 \times 10^{-5} \mathrm{mg}$ of $\mathrm{Cu}$ exposure (PEDROZO, 2003). This is equivalent to the ingestion of $6 \mathrm{mg}$ of contaminated periphyton from the treatment at $2.6 \mathrm{~g} / \mathrm{L}$ in this study. When considering mollusks, such as Acuta, with average weight of $24 \mathrm{mg}$ (SAHA et al., 2017), ingestion of $3.6 \times 10^{-6} \mathrm{mg}$ of $\mathrm{Cu}$ would be toxic (PEDROZO, 2003). This corresponds to 0.72 $\mathrm{mg}$ of periphyton from treatment at $2.6 \mathrm{~g} / \mathrm{L}$. These values only considered $\mathrm{Cu}$ ingestion, ignoring the other metals found in the sediment, which could cause a synergetic effect in these organisms. So, the frequent applications of algicide in the Guarapiranga Reservoir would not only impact the targeted cyanobacteria, but several other species, causing a cascade effect. 
The final result could lead to a loss of essential ecosystem services due to the loss of species (BEAULIEU et al., 2014).

\section{Conclusions}

The exposure of the periphyton biofilm to the sediment showed that this community is directly impacted by the presence of contamination in the Guarapiranga Reservoir. Even though alterations in biomass production and chlorophyll-a content were not observed, physiological changes regarding photosynthesis efficiency were identified through light saturation curves. Regarding bioaccumulation, not all the metals found in the sediment were also found in periphyton, and some, such as Fe and Al, even though in high concentration, were actually naturally found at the site due to geologic characteristics of the reservoir. Both $\mathrm{Cu}$ and $\mathrm{Ni}$ are two metals that are highly absorbed by periphyton and are clear signs of human action in the environment.

$\mathrm{Cu}$ is present due to frequent copper sulphate applications in the area from algicides against toxic cyanobacteria. On the other hand, Ni contamination is the result of industrial and metallurgical activities in the area close to the reservoir. The biological impact from the absorption of these metals can affect both periphyton composition and primary predators linked to this community. This could lead to an imbalanced food chain from the loss of species due to contamination or metal intoxication. Especially when considering $\mathrm{Cu}$ effects, the concentrations found in the periphyton were high enough to affect potential predators such as fish or snails. Therefore, periphytic biofilm can be considered a reflection of the contamination in the reservoir, and an indicator of the water quality in these environments.

\section{References}

ASSOCIAÇÃO BRASILEIRA DE NORMAS TÉCNICAS. Ecotoxicologia aquática toxicidade crônica - método de ensaio com algas (Chlorophyceae) - Normativa NBR 12648:2018. Brasília, 2019. Disponível em: http://www.abntcatalogo.com.br/norma.aspx?ID=391089. Acessado em 1.3.2019.

ABID, N.; ERRAIS, E.; DUPLAY, J.; BEREZA, A.; JRAD, A.; SCHÄFER, G.; GHAZIE, M.; SEHMI, K.; TRABELSI-AYADIA, M. Treatment of dye-containing effluent by natural 
clay. Journal of Clean Production, v. 86, n. 1, p. 432-440, 2015. https://doi.org/10.1016/j.jclepro.2014.08.043

ARRUDA, R.O.M.; DALMAS, F.B.; MILITÃO, F.A.; SANTOS, J.C.; GARCIA, A.P. Análise geoambiental aplicada ao estudo da relação entre qualidade da água e ocupação das margens da represa Guarapiranga (São Paulo - SP). Revista UNG - Geociências, Guarulhos, v. 15, n. 1, p. 77-93, 2016.

AUTHMAN, M.M.N.; ZAKI, M.; KHALLAF, E.A.; ABBAS, H.H. Use of Fish as Bioindicator of the Effects of Heavy Metals Pollution. Journal of Aquaculture Research \& Development, v. 6, n. 1, p. 328, 2015. http://dx.doi.org/10.4172/2155-9546.1000328

BEAULIEU, J.J.; MAYER, P.M.; KAUSHAL, S.S.; PENNINO, M.J. Effects of urban stream burial on organic matter dynamics and reach scale nitrate retention. Biogeochemistry, v. 121, n. $1, \quad$ p. 107-126, 2014. http://dx.doi.org/10.1007/s10533-014-9971-4

BREAULT, R.F.; COLMAN, J.A.; AIKEN, G.R.; MCKNIGHT, D. Copper speciation and binding by organic matter in copper-contaminated streamwater. Environmental Science and Technology, Washington, v. 30, n. 12, p. 3477-3486, 1996.

BRODERSEN, K.E.; HAMMER, K.J.; SCHRAMEYER, V.; FLOYTRUP, A.; RASHEED, M.A.; RALPH, P.J.; KÜHHL, M.; PEDERSEN, O. Sediment Resuspension and Deposition on Seagrass Leaves Impedes Internal Plant Aeration and Promotes Phytotoxic H2S Intrusion. Frontiers in Plant Sciences, 2017. https://doi.org/10.3389/fpls.2017.00657

CADMUS, P.; GUASCH, H.; HERDRICH, A.T.; BONET, B.; URREA, G.; CLEMENTS, W.H. Structural and Functional Responses of Periphyton and Macroinvertebrate Communities to Ferric $\mathrm{Fe}, \mathrm{Cu}$, and $\mathrm{Zn}$ in Stream Mesocosms. Environmental Toxicology and Chemistry, v. 37, n. 1, p. 1320-1329, 2018. https://doi.org/10.1002/etc.4070

CHEYLONI, G.; SLAVEYKOVA, V.I. Combined Effects of Trace Metals and Light on Photosynthetic Microorganisms in Aquatic Environment. Environments, Basel, v. 5, n. 7, p. 81, 2018. https://doi.org/10.3390/environments5070081

GARCIA, J.P.B. Avaliação de Chumbo (Pb), Mercúrio (Hg) e Cádmio (Cd) no sedimento na margem da represa de Guarapiranga: Uma questão de saúde pública. Dissertação (Mestrado em Ciências da Saúde) - Universidade de Santo Amaro, Santo Amaro - 2017. 60 p.

GARDHAN, S.; CHARITON, A.A.; HOSE, G.C. Direct and indirect effects of coppercontaminated sediments on the functions of model freshwater ecosystems. Ecotoxicology, Berlin, v. 24, n. 1, p. 61-70. https://doi.org/10.1007/s10646-014-1355-y

HAMADA, Y.Z.; COX, R.; HAMADA, H. Cu2+-Citrate dimer complexes in aqueous solutions. Journal of Basic and Applied Sciences, Ontario, v. 11, n. 1, p. 583-589, 2015. https://doi.org/10.6000/1927-5129.2015.11.78

INTAGWONGSE, M.; DEAN, J.R. Uptake of heavy metals by vegetable plants grown on contaminated soil and their bioavailability in the human gastrointestinal tract. Food Additives \& Contaminants, v. 23, n. 1, p. 36-48, 2006. https://doi.org/10.1080/02652030500387554 
JAFARINEJAD, S. Recent developments in the application of sequencing batch reactor (SBR) technology for the petroleum industry wastewater treatment. Chemistry International, v. 3, n. 3, 241-250, 2017.

JINSHUI, Y.; JING, C.; GUANLAN, X.; HONGLI, Y. Lipid production combined with biosorption and bioaccumulation of cadmium, copper, manganese and zinc by oleaginous microalgae Chlorella minutissima UTEX2341. Bioresource Technology, v. 175, n. 1, p. 537544, 2015. https://doi.org/10.1016/j.biortech.2014.10.124

JIALI, Y.; CILAI, T.; FENGWU, W.; YONGHONG, W. Co-contamination of $\mathrm{Cu}$ and Cd in paddy fields: Using periphyton to entrap heavy metals. Journal of Hazardous Materials, v. $304, \quad$ n. $1, \quad$ p. $150-158,2016 . \quad$ http://dx.doi.org/10.1016/j.jhazmat.2015.10.051

KABRA, K.; CHAUDHARY, R.; SAWHNEY, R.L. Solar photocatalytic removal of Cu(II), $\mathrm{Ni}(\mathrm{II}), \mathrm{Zn}(\mathrm{II})$ and $\mathrm{Pb}(\mathrm{II})$ : Speciation modeling of metal-citric acid complexes. Journal of Hazardous Materials, $\quad$ v. $155, \quad$ n. $\quad 3, \quad$ p. $424-432, \quad 2008$. https://doi.org/10.1016/j.jhazmat.2007.11.083

KUMAR, K.S.; DAHMS, H.U.; LEE, J.S.; KIM, H.C.; LEE, W.C.; SHIN, K.H. Algal photosynthetic responses to toxic metals and herbicides assessed by chlorophyll a fluorescence. Ecotoxicology and Environmental Safety, v. 104, n. 1, p. 51-71, 2014. https://doi.org/10.1016/j.ecoenv.2014.01.042

LAMBERT, A.S.; PESCE, S.; FOUQUIER, A.; GAHOU, J.; COQUERY, M.; DABRIN, A. Improved short-term toxicity test protocol to assess metal tolerance in phototrophic periphyton: toward standardization of PICT approaches. Environmental Science and Pollution Research, Berlin, v. 22, n. 6, p. 4037-4045. 2015. https://doi.org/10.1007/s11356014-3505-4

LEAL, P.R. Geoestatística e ecotoxicologia como ferramentas para gestão de reservatórios: Estudo de Caso - Reservatório Guarapiranga- BR. Dissertação (Mestrado em Ecologia) - Universidade de São Paulo, São Paulo, 2017. 151 p.

LEAL， P.R.; MOSCHINI-CARLOS， V.; LÓPEZ-DOVAL， J.C.; CINTRA， J.P.; YAMAMOTO, J.K.; BITENCOURT, M.D.; SANTOS, R.F.; ABREU, G.C.; POMPÊO, M.L.M. Impact of copper sulfate application at an urban Brazilian reservoir: A geostatistical and ecotoxicological approach. Science of the Total Environment, v. 618, n. 1, p. 621-634, 2018. https://doi.org/10.1016/j.scitotenv.2017.07.095

LEI, X.; CRUZ, J.A.; SAVAGE, L.J.; KRAMER, D.M.; CHEN, J. Plant photosynthesis phenomics data quality control. Bioinformatics, Oxford, v. 31, n. 11, p. 1796-1804, 2015. https://doi.org/10.1093/bioinformatics/btu854

LIMA, I.V. Ferro. In: AZEVEDO, F.A.; CHASIN, A.A.M. (Eds) Metais: Gerenciamento da Toxicidade, $1^{a}$ ed. São Paulo: Atheneu/ Intertox, 2003. p. 99-126. 
Liu P, Borella PF, Bozi M, Kokol V, Oksman K, Mathew AP (2015) Nanocelluloses and their phosphorylated derivatives for selective adsorption of $\mathrm{Ag}+, \mathrm{Cu} 2+$ and $\mathrm{Fe} 3+$ from industrial effluents. J Hazard Mater 294:177-185. https://doi.org/10.1016/j.jhazmat.2015.04.001

MARTINS, I. Manganês. In: AZEVEDO, F.A.; CHASIN, A.A.M. (Eds) Metais: Gerenciamento da Toxicidade, $1^{\text {a }}$ ed. São Paulo: Atheneu/ Intertox, 2003. p. 67-96.

MEGURO, M. Métodos em ecologia. São Paulo: Instituto de Biociências- Universidade de São Paulo, 2000.

MELO, V.F.; ANDRADE, M.; BATISTA, A.H.; FAVARETTO, N.; GRASSI, M.T.; CAMPOS, M.S. Chumbo e Zinco em águas e sedimentos de área de mineração e metalurgia de metais. Quimica Nova, v. 35, n. 1, p. 22-29, 2012. http://dx.doi.org/10.1590/S010040422012000100005

MELVIN, S.D.; LEUSCH, F.D.L. Removal of trace organic contaminants from domestic wastewater: A meta-analysis comparison of sewage treatment technologies. Environmental International, v. 92, n. 1, p. 83-188, 2016. https://doi.org/10.1016/j.envint.2016.03.031

OLIVEIRA, J.P. Níquel. In: AZEVEDO, F.A.; CHASIN, A.A.M. (Eds) Metais: Gerenciamento da Toxicidade, $1^{a}$ ed. São Paulo: Atheneu/ Intertox, 2003. p. 127-142.

OTOMO, J.I. Contribuição antrópica na qualidade das águas da represa do Guarapiranga. Um estudo sobre interferentes endócrinos. Tese (Doutorado em Tecnologia Nuclear), Universidade de São Paulo - São Paulo, 2015. 216 p.

PANDEY, L.K.; BERGEY, E.A. Exploring the status of motility, lipid bodies, deformities and size reduction in periphytic diatom community from chronically metal $(\mathrm{Cu}, \mathrm{Zn})$ polluted waterbodies as a biomonitoring tool. Science of the Total Environment, v. 550, n. 1, p. 372381, 2016. https://doi.org/10.1016/j.scitotenv.2015.11.151

PEDROZO, M.F.M. Cobre. In: AZEVEDO, F.A.; CHASIN, A.A.M. (Eds) Metais: Gerenciamento da Toxicidade, $1^{a}$ ed. São Paulo: Atheneu/ Intertox, 2003. p. 143-186.

PILSKALN, C.H.; CHURCHILL, J.H.; MAYER, L.M. Resuspension of Sediment by Bottom Trawling in the Gulf of Maine and Potential Geochemical Consequences. Conservation Biology, v. 12, n. 6, p. 1223-1229, 1998.

POMPÊO, M.L.M., KAWAMURA, P.; MOSCHINI-CARLOS, V.; SILVA, S.C.; LOBO, F.L.; MEIRELLES, S.T. Heterogeneidade espacial horizontal da qualidade da água no reservatório rio grande, complexo Billings, São Paulo - Brasil. In: POMPÊO, M.L.M.; MOSCHINI-CARLOS, V.; SILVA, S.C.; LÓPEZ-DOVAL, J.C. (Eds) Ecologia de reservatórios e interfaces. 1 ed. São Paulo : Instituto de Biociências da Universidade de São Paulo. 2015, p. 72-81.

POMPÊO, M.; PADIAL, P.R.; MARIANI, C.F.; CARDOSO-SILVA, S.; MOSCHINICARLOS, V.; SILVA, D.C.V.R.; PAIVA, T.C.B.; BRANDIMARTE, A.L. Biodisponibilidade de metais no sedimento de um reservatório tropical urbano (reservatório Guarapiranga - São Paulo (SP), Brasil): há toxicidade potencial e heterogeneidade espacial? Geochimica Brasiliensis, São Paulo, v. 27, n. 2, p. 104-119, 2013. https://doi.org/10.21715/gb.v27i2.364 
POTVIN, C. ANOVA: experimental layout and analysis. In: SCHNEIDER, S.M.; GUREVITCH, J. (Eds) Design and analysis of ecological experiments. $2^{\mathrm{a}} \mathrm{ed}$, New York: Oxford university press, 2001. p. 63-77.

RIBEIRO, M.A.; CAMARGO, E.; FRANCA, D.T.; CALASANS, J.T.; TRIGO, A.J. Gestão da Água e Paisagem Cultural. Revista da Universidade Federal de Minas Gerais, Belo Horizonte, v. 20, n. 2, p. 45-67, 2016.

ROBERTS, M.J.; LONG, S.P.; TIESZEN, L.L.; BEADLE, C.L. Measurement of plant biomass and net primary production. In: COOMBS, J.; HALL, D.O.; LONG, S.P.; SCURLOCK, J.M.O. (Eds). Techniques in bioproductivity and photosynthesis. $2^{\mathrm{a}}$ ed, Oxford: Pergamon Press, 2014. p. 1-19.

RODRIGUES, M.E.F.; SOUZA, V.C.; POMPÊO, M.L.M. Levantamento florístico de plantas aquáticas e palustres na represa de Guarapiranga, São Paulo, Brasil. Boletim de Botânica da Universidade de São Paulo, São Paulo, v. 35, n. 1, p. 1-64, 2017. https://doi.org/10.11606/issn.2316-9052.v35ip1-64.

ROSA, A.H.; SILVA, A.A.M.J.; MELO, C.A.; MOSCHINI-CARLOS, V.; GUANDIQUE, M.E.G.; FRACETO, L.F.; LOURENÇO, R.W. Diagnóstico ambiental e avaliação do uso e ocupação do solo visando a sustentabilidade da represa de Ituparanga, importante área da bacia do médio tietê. In POMPÊO, M.L.M.; MOSCHINI-CARLOS, V.; SILVA, S.C.; LÓPEZ-DOVAL, J.C. (Eds) Ecologia de reservatórios e interfaces. 1 ed. São Paulo: Instituto de Biociências da Universidade de São Paulo. 2015. p. 212-231.

SAHA, C.; PARVEEN, S.; CHAKRABORTY, J.; PRAMANIK, S.; ADITYA, G. Life table estimates of the invasive snail Physa acuta (Draparnaud, 1805), occurring in india. Ekológia, Bratislava, v. 36, n. 1, p. 60-68, 2017. https://doi.org/10.1515/eko-2017-0006

SANTOS, C.R. Alumínio. In: AZEVEDO, F.A.; CHASIN, A.A.M. (Eds) Metais: Gerenciamento da Toxicidade, $1^{a}$ ed. São Paulo: Atheneu/ Intertox, 2003. p. 1-34.

SCHEIBENER, S.A.; RIVERA, N.A.; HESTERBERG, D.; DUCKWORTH, O.W.; BUCHWALTER, D.B. Periphyton uptake and trophic transfer of coal fly ash delivered trace elements. Environmental Toxicology and Chemistry, Toronto, v. 36, n. 1, p. 2991-2996, 2017. https://doi:10.1002/etc.3864

SCHMITT-JANSEN, M.; BLEY, L.M.; KRUMBIEGEL, M.L.; ROTTER, A. Induced community tolerance of periphyton towards combined salt and toxic stress. Freshwater Biology, v. 61, n. 1, p. 2152-2161, 2016. https://doi.org/10.1111/fwb.12799

SCHROPP, S.J. Interpretations of metal concentrations in estuarine sediments of Florida using Aluminium as a reference element. Estuaries, v. 13, n. 3, p. 227-235, 1990.

SILVA, C.S. Cromo. In: AZEVEDO, F.A.; CHASIN, A.A.M. (Eds) Metais: Gerenciamento da Toxicidade, $1^{\mathrm{a}}$ ed. São Paulo: Atheneu/ Intertox, 2003. p. 35-66.

SILVA, L.F. Reconstrução paleolimnólogica da eutrofização na represa de Guarapiranga com base em multitraçadores biogeoquimicos. Tese - (Doutorado) - 
Universidade Estadual Paulista Júlio de Mesquita Filho, Instituto de Biociências de Rio Claro, 2013. $225 \mathrm{p}$.

SILVA, L.S.; FERREIRA, F.J.; FÁVARO, D.I.T. Avaliação da concentração de metais tóxicos em amostras de sedimentos dos reservatórios do complexo Billings (Guarapiranga e Rio Grande). Geochimica Brasiliensis, São Paulo, v. 31, n. 1, p. 37-56, 2017. https://doi.org/10.21715/GB2358-2812.2017301037

SOUSA, M.L.; CHOW, F.; POMPÊO, M.L.M. Community-level changes in periphytic biofilm caused by copper contamination. Journal of Applied Phycology, 2019. https://doi.org/10.1007/s10811-019-1734-0

TAKAMURA-ENYA, T.; TOKUTAKE, M. Novel speciation analysis of copper in river water: observation of soluble anionic copper-ligand complexes. Limnology, v. 17, n. 2, p. 117-125, 2016. https://doi.org/10.1007/s10201-015-0468-1

TANG, W.; CUI, J.; SHAN, B.; WANG, C.; ZHANG, W. Heavy Metal Accumulation by Periphyton Is Related to Eutrophication in the Hai River Basin, Northern China. Plos One, São Francisco. https://doi.org/10.1371/journal.pone.0086458.

TORGAN, L.C.; BERTOLlI, L.M.; TALGATTI, D.M.; SALMONI, S. Colonização e sucessão do perifíton. In: SCHWARZBOLD, A.; BURLIGA, A.L.; TORGAN, L.C. (Eds.) Ecologia do perifíton. São Carlos: Rima, 2013. p. 45-58

TORRES, P.B.; CHOW, F.; FURLAN, C.M.; MANDELLI, F.; MERCADANTE, A.; SANTOS, D.Y.A.C. Standardization of a protocol to extract and analyze chlorophyll a and carotenoids in Gracilaria tenuistipitata Var. Liui. Zhang and Xia (Rhodophyta). Brazilian Journal of Oceanography, São Paulo, v. 62, n. 1, p. 57-63, 2014. https://doi.org/10.1590/s1679-87592014068106201

WEYER, K.M.; BUSH, D.R.; DARZINS, A.; WILSON, B.D. Theoretical Maximum Algal Oil Production. Bioenergy Research, v. 3, n. 2, p. 204-213, 2010. https://doi.org/10.1007/s12155-009-9046-x

WINKELMAN, C.; SCHNEIDER, J.; MEWES, D.; SCHMIDT, S.; WORISCHKA, S.; HELLMAN, C.; BENNDOR, J. Top-down and bottom-up control of periphyton by benthivorous fish and light supply in two streams. Freshwater Biology, v. 59, n. 1, p. 8032014. https://doi.org/10.1111/fwb.12305 


\section{Supplementary Material}

Table I: Complete composition of LC Oligo medium (ABNT, 2018 - with adaptations) and amount of each stock solution necessary for preparing $1 \mathrm{~L}$ of LC Oligo medium

\begin{tabular}{|c|c|c|c|}
\hline $\begin{array}{l}\text { Stock } \\
\text { Solution }\end{array}$ & Compound & Total / L of deionized water & $\begin{array}{l}\text { Stock solution / L } \\
\text { of final LC Oligo }\end{array}$ \\
\hline $\mathbf{I}$ & Calcium Nitrate tetrahydrate & $40000 \mathrm{mg}$ & $1 \mathrm{ml}$ \\
\hline II & Potassium nitrate & $100000 \mathrm{mg}$ & $1 \mathrm{ml}$ \\
\hline III & Magnesium sulfate heptahydrate & $30000 \mathrm{mg}$ & $1 \mathrm{ml}$ \\
\hline IV & Dibasic potassium phosphate & $40000 \mathrm{mg}$ & $1 \mathrm{ml}$ \\
\hline \multirow[t]{7}{*}{$\mathbf{V}$} & Copper sulphate pentahydrate & $30 \mathrm{mg}$ & $0,5 \mathrm{ml}$ \\
\hline & $\begin{array}{l}\text { Ammonium molybdate } \\
\text { tetrahydrate }\end{array}$ & $60 \mathrm{mg}$ & \\
\hline & Zinc Sulphate heptahydrate & $60 \mathrm{mg}$ & \\
\hline & Cobalt chloride hexahydrate & $60 \mathrm{mg}$ & \\
\hline & Manganese nitrate tetrahydrate & $60 \mathrm{mg}$ & \\
\hline & Citric acid monohydrate & $60 \mathrm{mg}$ & \\
\hline & Boric acid & $60 \mathrm{mg}$ & \\
\hline \multirow[t]{2}{*}{ VI } & Iron chloride hexahydrate & $625 \mathrm{mg}$ & $1 \mathrm{ml}$ \\
\hline & Iron sulphate heptahydrate & $625 \mathrm{mg}$ & \\
\hline VII & Sodium bicarbonate & $15000 \mathrm{mg}$ & $1 \mathrm{ml}$ \\
\hline
\end{tabular}




\section{CONCLUSÕES GERAIS}

O método de tanque de cultivo foi satisfatório em produzir um perifíton homogêneo para aplicação em testes ecotoxicológicos, apesar de apresentar diferenças em relação ao inóculo. Quando realizados os testes ecotoxicológicos aplicados a contaminantes isolados cobre e cafeína - foi observado que os resultados obtidos incluíram principalmente alterações na atividade fotossintética (YII, Fv/Fm e Ik) e desaparecimento de espécies. Já quando realizados os testes com o sedimento do reservatório de Guarapiranga, foi observado que os diferentes metais presentes no sedimento interagiram de forma diferente com o biofilme, gerando diferentes perfis de bioacumulação. Novamente a atividade fotossintética foi um indicativo da contaminação, se mostrando assim um parâmetro sensível para se avaliar as alterações no perifíton.

Sendo assim, seguem as principais conclusões obtidas por capítulo:

No Capítulo 1, observou-se que o estudo do perifíton como bioindicador pode ajudar a compreender o impacto em diversos serviços ecossistêmicos, visto que o mesmo atua de forma direta e indireta em vários deles. Foi observado principalmente que o perifíton tem uma influência positiva e direta com serviços de regulagem (como ciclos biogeoquímicos e produção primária) e negativa e indireta com serviços culturais (devido às florações de algas que causam danos à paisagem). Uma vez que a capacidade do perifíton em prover e indicar serviços está ligada com sua composição, os resultados dos testes ecotoxicológicos são ferramentas úteis para se avaliar como esses serviços virão a ser afetados após a contaminação. Sendo assim é importante compreender as como a estrutura do perifíton é modificada na presença de um contaminante e como esses dados se relacionam com os serviços de interesse.

No Capítulo 2 foi mostrado que o método de tanque de cultivo desenvolvido teve a vantagem de criar uma quantidade razoável de biofilme perifítico, devidamente aclimatado em condições de laboratório, de forma homogênea e com menor custo se comparado a outros métodos de cultivo. A desvantagem ainda foi a dificuldade em se manter a mesma diversidade 
e densidade encontradas no inóculo inicial, visto que algumas espécies não se adaptaram tão bem ao ambiente controlado do laboratório, principalmente em relação ao grupo Chlorophyceae. Isso torna a comparação direta entre os resultados encontrados nos testes de ecotoxicidade e os danos ao ambiente desaconselhável, sendo necessária cautela na extrapolação dos dados para as condições reais de um ecossistema aquático. Isso significa que os resultados obtidos servem como um sinal de como a contaminação pode agir nos diferentes grupos de algas, afetar a produção primária e a atividade fotossintética, servindo como suporte a outras metodologias de campo ou laboratoriais para a tomada de decisão.

No Capítulo 3, a exposição do perifíton cultivado às diferentes concentrações de cobre mostrou que mesmo na menor concentração estudada $(0,013 \mathrm{mg} / \mathrm{L})$, já foram encontradas alterações tanto fisiológicas quanto estruturais no biofilme. Foi observado que até certa concentração $(0,1 \mathrm{mg} / \mathrm{L})$ há o aumento da densidade algal, entretanto esse aumento foi gerado principalmente pela maior densidade de cianobactérias, em detrimento do grupo Chlorophyceae. Na maior concentração estudada, além de grande dominância também houve queda na produção primária e menor ponto de saturação luminosa, indicando que o cobre presente afetou consideravelmente a comunidade.

No Capítulo 4, foi observado que o biofilme possui a capacidade de metabolizar rapidamente a cafeína, principalmente nas primeiras 24 horas de exposição. Entretanto, ainda assim são observados diversos efeitos no perifíton ao final de 15 dias, mesmo após toda a concentração disponível já haver sido metabolizada. A contaminação causou a diminuição do ponto de saturação luminosa já na menor concentração estudada $(20 \mu \mathrm{g} / \mathrm{L})$, além de também alterar a estrutura do perifíton. Na maior concentração estudada (300 $\mu \mathrm{g} / \mathrm{L})$ houve queda acentuada na densidade algal e menor diversidade, sendo as diatomáceas o grupo menos impactado pela contaminação. Além disso, ainda no período inicial de $24 \mathrm{~h}$ de exposição, foi possível encontrar cafeína não metabolizada acumulada no biofilme, o que poderia causar contaminação nas espécies consumidoras do perifíton.

No Capítulo 5, após a exposição ao sedimento do reservatório de Guarapiranga, foi observada grande acumulação de metais no biofilme perifítico. Isso se deve primeiramente a alta contaminação encontrada no ponto amostrado, mas também a capacidade do biofilme em acumular contaminantes presentes na coluna d'água. Dos seis metais encontrados no perifíton 
após o período de exposição, três deles apresentaram alta correlação entre a concentração de sedimento na água e a concentração encontrada no biofilme: $\mathrm{Cu}$, Ni e $\mathrm{Mn}$. Desses, o que apresentou maior potencial de dano ambiental é o cobre, uma vez que é derivado principalmente da ação antrópica, e possui grande potencial de transferência para níveis tróficos superiores. Além disso, como observado no Capítulo 3, o cobre causa diversos danos ao perifíton. Isto é preocupante, pois o cobre é aplicado em grandes quantidades no reservatório Guarapiranga e em outros reservatórios do Estado de São Paulo.

Portanto, observa-se que o biofilme perifítico respondeu rapidamente a presença dos contaminantes, sugerindo que as substâncias estudadas e normalmente encontradas em reservatórios podem gerar diversos danos aos produtores primários. Os parâmetros mais sensíveis e indicativos da contaminação foram principalmente a densidade de Chlorophyceae e o ponto de saturação luminosa, que em geral apresentaram menores valores após a contaminação. Esses parâmetros podem ser diretamente ligados com serviços de produção primária, os quais são diretamente dependentes do perifíton. Além disso foi possível também observar a bioacumulação de compostos, o que abre caminho para testes ecotoxicológicos envolvendo espécies consumidoras do perifíton, aprofundando assim ainda mais os estudos envolvendo essa comunidade.

Enfim, mostrou-se que o estudo do perifíton é uma ferramenta importante na conservação dos reservatórios, e que seu uso em testes ecotoxicológicos é uma ferramenta com grande potencial de aplicação em estudos ambientais e na criação de normativas para auxiliar na manutenção da qualidade da água. 